\title{
Ambiguous isotopic and geochemical signatures resulting from limited melt interactions in a seemingly composite pluton: a case study from the Strzegom-Sobótka Massif (Sudetes, Poland)
}

\author{
J. Domańska-Siuda ${ }^{1} \cdot$ E. Słaby ${ }^{2} \cdot$ A. Szuszkiewicz ${ }^{3}$
}

Received: 10 August 2018 / Accepted: 10 February 2019 / Published online: 20 March 2019

(c) The Author(s) 2019

\begin{abstract}
The western part of the late Variscan Strzegom-Sobótka massif exemplifies an intrusion that formed in a multi-component system. The system shows ambiguous isotopic and geochemical signatures and presents a seemingly composite character [biotite granite with negligible amount of hornblende (HBG) and microgranular mafic enclaves (MMEs)]. The melts responsible for forming granitic rock and its MMEs were not derived from contrasting crustal and mantle sources but from different crustal domains. These melts exhibit hybrid characteristics due to subsequent contamination processes. The data suggest two different stages of hybridization of two geochemically distinct magmas corresponding to granite and enclaves. The processes were temporally and spatially distinct. Heterogeneous protoliths and hybridization made these magma isotopic signatures and trace element patterns ambiguous. The main mechanism involved in developing granitic rocks was fractional crystallization (FC); the mechanism responsible for MME composition was mixing, but other local processes were also involved in rock formation. Generally, the FC signature was not obscured by the hybrid mafic melt input. This felsic-mafic melt interaction was a limited one-sided process. Granitic melt was changed by the presence of small mafic magma blobs, but their influence on granite crystallization was negligible. The massif is thus an ideal example of an environment where MMEs coexist with a granitic body, although MMEs do not determine the actual composite character of the pluton. The early stage of Variscan pluton formation within the Bohemian Massif and adjacent areas was shaped by interacting mantle- and crust-derived melts. The pluton described in this paper belongs to the late stage of Variscan magmatism. It is a multi-component system shaped by the participation of melts derived from heterogeneous crustal domains. The presence of enclaves does not explicitly indicate their dominant role in the formation of composite plutons of crust-mantle origin. It is decisive to determine whether the ambiguous signatures appearing in such cases truly indicate both of these sources.
\end{abstract}

Keywords Strzegom-Sobótka massif · Granite $\cdot$ Microgranular mafic enclave $\cdot$ Magma evolution $\cdot$ Magma mixing and mingling $\cdot$ Geochemical modelling

Electronic supplementary material The online version of this article (https://doi.org/10.1007/s00531-019-01687-w) contains supplementary material, which is available to authorized users.

J. Domańska-Siuda

j.domanska@uw.edu.pl

1 Faculty of Geology, Institute of Geochemistry, Mineralogy and Petrology, University of Warsaw, Żwirki and Wigury 93, 02-089 Warsaw, Poland

2 Institute of Geological Sciences, Polish Academy of Sciences, Research Center in Warsaw, Twarda 51/55, 00-818 Warsaw, Poland

3 Institute of Geological Sciences, University of Wrocław, pl. M. Borna 9, 50-204 Wrocław, Poland

\section{Introduction}

Granitic rocks, which constitute a major part of the continental crust, are found in nearly all tectonic environments. The vast majority of granite intrusions are located in orogenic regions (collision zones), where the melting of crustal rocks is initiated by rising mafic melt (related to subduction) or by thickening of the crust. Melting of the crust driven by heat from the mantle and mantle melts represents a very complicated system controlled by many factors, including chaotic magma interactions.

Such interactions have been demonstrated to play significant roles in the petrogenesis of many granitic plutons worldwide. Understanding this process yields better insight 
into lithosphere dynamics (e.g., Walker and Skelhorn 1966; Reid et al. 1983; Vernon 1984, 1990; Furman and Spera 1985; Didier 1987; Frost and Mahood 1987; Poli and Tommasini 1991; Didier and Barbarin 1991, 2005; Perugini and Poli 2012; Wiebe et al. 1997; Silva et al. 2000; Ratajeski et al. 2001; Janoušek et al. 2004; Liu et al. 2013; Farner et al. 2014; Kocak and Zedef 2016).

Most of the European Variscan granitic massifs may be related to crust-mantle interaction. Such granitic massifs often present calc-alkaline to high-K calc-alkaline compositions and contain mafic enclaves, features that are typically interpreted as indicators of mixed crust-mantle magma sources (Finger et al. 1997). However, this interpretation is not necessarily correct. Roberts and Clements (1993) argue that calc-alkaline magmatism need not be connected to crust-mantle magma sources and may result from crust melting only: "the chemistry of the magmas depends primarily on the nature of the protoliths rather than the processes involved in their generation". Determining that the case of only crustal protoliths occurs is difficult because processes of magma differentiation are also important and may obscure some primary signatures. Ambiguities in trace element and isotope evidence in granite and its enclaves (low isotope contrast with their host) make solving the protolith problem difficult (Pin et al. 1990). If two melts exchange components and the process is long enough, the melts should maintain consistent Harker trends. A short exchange process may result in deviation (e.g., experiments by De Campos et al. 2008 , 2011). Thus, the time and place of interaction, the volume of interacting melts and their chemical and physical features are important factors influencing homogenization and equilibration processes. For tracking these processes, whole-rock analyses and single mineral studies are very useful. Whole-rock analyses provide average information from signals (partly overlapping) of all subsequent processes and are mostly used as a base for geochemical modelling of the mechanisms of magma differentiation. Single domains of minerals may preserve evidence of different differentiation mechanisms (Słaby et al. 2007a, b, 2008, 2012; McLeod et al. 2010; Miles et al. 2013; Michel et al. 2016; Laurent et al. 2017). The combination of both sets of data may be helpful in resolving a problem regarding the real nature of a pluton that is characterized as an apparently composite pluton.

The presence of MMEs in felsic plutons is considered important evidence of melt-melt interaction (Didier 1973, 1991; Castro et al. 1990; Vernon 1984, 1990, 2010; Frost and Mahood 1987; Didier and Barbarin 1991, 2005; Hibbard 1991; Orsini et al. 1991; Wiebe et al. 1997). MMEs can also shed light on the magma source, the mode of emplacement of mafic and granitoid magmas and the dynamics of magma chambers (Vernon et al. 1988; Hrouda et al. 1999; Paterson et al. 2004; Perugini and Poli 2000; Słaby and Martin 2008; Kumar 2010; Perugini and Poli 2012).

However, the presence of enclaves, even if they represent evidence of melt interactions, cannot be an unambiguous indicator of the main mechanism of pluton formation and testify to a crust-mantle melt origin. The Strzegom-Sobótka pluton is a good example of such a complicated environment. The apparently composite pluton shows no affinity with other Central European Variscan granitic massifs. This pluton has been dated at 305-295 Ma (Turniak et al. 2014) and is considered an example of the most recent product of granitic plutonism in the Central European Variscides. Pilot studies have shown that the granite facies in the western part of this massif clearly exhibits the features of limited magma mixing-mingling processes due to the presence of unbalanced quantities of mafic and felsic magma (Domańska and Słaby 2004; Domańska-Siuda and Słaby 2005). Further, enclaves and granite show vagueness in their isotope signatures, which was first reported by Pin et al. (1989). Careful observations of mineral growth textures and geochemical models of magma evolution indicate that granite and enclave evolution paths were separate, which may indicate that the melts might have been emplaced into the magma chamber at least partly as hybrids. Different geochemical and isotopic characteristics of granite/enclave melts do not exclude crustal protoliths for both melts. We find this problem worth discussing because the massif is exceptional among all the Central European late Variscan granite plutons. The other plutons clearly show mantle-crust interaction without any ambiguity in isotope signatures and trace element patterns. We discuss the problem using a set of new tools aimed at identifying and quantifying the processes responsible for the magmatic evolution of the pluton. Whereas the mineral compositions and rock textures are used to define local processes, geochemical modelling is critical for the diagnosis of the whole pluton's formation.

\section{Geological setting and field relationships}

The late stages of the development of the European Variscides were accompanied by extensive granitoid magmatism from the Late Devonian-Visean to the Late Carboniferous-Early Permian. Changes in tectono-thermal conditions within the evolving orogen resulted in the formation of a variety of granite types with distinct geochemical signatures and ages (e.g., Schaltegger 1997; Finger et al. 1997, 2009). In the Sudetes, at the north-eastern margin of the Bohemian Massif, the intermittent process of crustal melting resulted in the formation of a number of late- to post-orogenic granitic plutons that were emplaced in roughly two phases dated to ca. 340-330 Ma and ca. 320-295 Ma (Finger et al. 1997; 
Mazur et al. 2007 and references therein; Finger et al. 2007; Słaby and Martin 2008; Turniak et al. 2014). Older granitoids are believed to have been generated as a result of nappe stacking that led to an increase in heat in the thickened orogenic root (e.g., Franke 2000). Younger granitoids intruded after the cessation of the Variscan convergence; the most recent granitoids are coeval with bimodal volcanism (e.g., Kryza and Awdankiewicz 2012; Awdankiewicz et al. 2014; Turniak et al. 2014). Thus, younger granitic plutonism could have resulted from decompression melting related to lithospheric thinning in the post-Variscan extensional regime (e.g., Henk 1997). Most of the granitic bodies are composite plutons that crystallized from melts derived from multiple sources (e.g., Pin et al. 1989; Finger et al. 1997, 2007; Gerdes and Wörner 2000; Žák et al. 2014).

The Strzegom-Sobótka Massif (SSM) is located in the Sudetes (SW Poland) at the north-eastern periphery of the Bohemian Massif of the Central European Variscides between the WNW-ESE-trending regional tectonic zones of the Upper Elbe and the Middle Odra (Fig. 1). The Sudetes comprise Neoproterozoic-Lower Paleozoic volcano-sedimentary sequences and magmatic suites that were metamorphosed by Cadomian and Variscan orogenic events and are covered in places by the Upper Devonian-Lower Carboniferous sediments of intramontane troughs (Żelaźniewicz 1997; Mazur et al. 2006). In the Late Carboniferous-Earliest Permian, granitic plutonism resulted in the formation of a number of granitic bodies that are widely distributed throughout the region (Fig. 1). The NE-SW-trending Sudetic Boundary Fault, a Late Variscan structure that was reactivated during the Alpine orogeny (Aleksandrowski et al. 1997; Badura et al. 2007 and ref. therein), divides the Sudetes into the elevated mountainous Sudetic Block in the SW and the strongly peneplained lowlands of the Fore-Sudetic Block in the NE.

The SSM is located on the north-eastern side of the Sudetic Boundary Fault, in the Fore-Sudetic Block, approximately $50 \mathrm{~km}$ southwest of Wrocław (Fig. 1). At their current level of exposure, the granites extend over $50 \mathrm{~km}$ WNW-ESE between Sobótka in the south-east and Jawor in the north-west. The granitic magmas intruded into a mildly metamorphosed volcano-sedimentary sequence that bears palaeontological records corresponding to ages from the Lower Paleozoic to the lower part of the Upper Carboniferous (Jerzmański 1970; Jerzmański and Teller 1971; Grocholski and Sawicki 1992). In the east, the granites are in contact with the ca. 400 Ma mafic-ultramafic suite of the Ślęża massif, which is a part of the Central Sudetic Ophiolite (Oliver et al. 1993; Dubińska et al. 2004; Kryza and Pin 2010). In the south, the SSM adjoins the Góry Sowie Block, which mainly comprises amphibolite-facies gneisses and amphibolites, partly migmatized and derived from the Neoproterozoic-Cambrian volcano-sedimentary sequence and magmatic rocks (Gunia 1999; Kryza and Fanning 2007 and references therein). The Góry Sowie Block has been interpreted as a fragment of the subducted middle lower continental crust (e.g., Mazur et al. 2006). To the west and south-west, the Sudetic Boundary Fault separates the SSM from the Kaczawa Unit, which is composed of a low-grade Neoproterozoic/Cambrian to Upper Devonian/Lower Carboniferous metasedimentary and metavolcanic succession, interpreted to comprise fragments of a Variscan accretionary prism (Baranowski et al. 1990; Kryza and Zalasiewicz 2008 and references therein).

The SSM comprises four main varieties of granite, which intruded as separate magma batches: biotite granite with negligible amount of hornblende (which is a subject of this study and is henceforth referred to as HBG), biotite granite devoid of hornblende, two-mica granite and biotite granodiorite (Majerowicz 1972; Pin et al. 1989; Puziewicz 1990) (Fig. 1). They show different paths of magma differentiation and different paths of post-magmatic alterations. The narrowing of the exposure of these granites east of Strzegom divides the SSM into an eastern part, which is built of twomica granite and biotite granodiorite, and a western part, which is composed of biotite granite varieties. Currently, contacts between western and eastern parts is not observed in the field.

Recent low-error zircon dating (Turniak et al. 2014) has indicated that the SSM was amalgamated between ca. 305 and $295 \mathrm{Ma}$, beginning with the two-mica granite and followed by the biotite granodiorite and then by the biotite granite varieties. Similar conclusion is drawn by Pin et al. (1989) on a base of whole-rock isotope investigations. Pin et al. (1989) show very different initial $\mathrm{Sr}$ isotope ratios for the granites of the western and eastern parts of the SSM. They also point to significant differences between granite varieties within each of the two parts.

\section{Sampling and analytical methods}

Over 100 rock samples of the biotite granite variety HBG from western SSM block (henceforth referred to as HBG) and its enclaves (MME), xenoliths and mafic schlieren were collected (Table 1, Supplementary Material). Extreme care was taken to choose samples that were non-weathered and representative, i.e., devoid of mafic schlieren, pegmatites, aplites, and features of hydrothermal alteration.

Cathodoluminescence (CL) petrography was carried out on polished thin sections using a Nikon Eclipse E600 POL polarizing microscope equipped with a Citl-CCL 8200 cold cathode stage at the Institute of Geological Sciences, University of Wrocław, Poland. CL was excited at a gun current of $400-500 \mathrm{~mA}$ and an accelerating voltage of $10-15 \mathrm{kV}$, and it was digitally recorded with a Canon 590 camera at an exposure time of 1-8 s. 


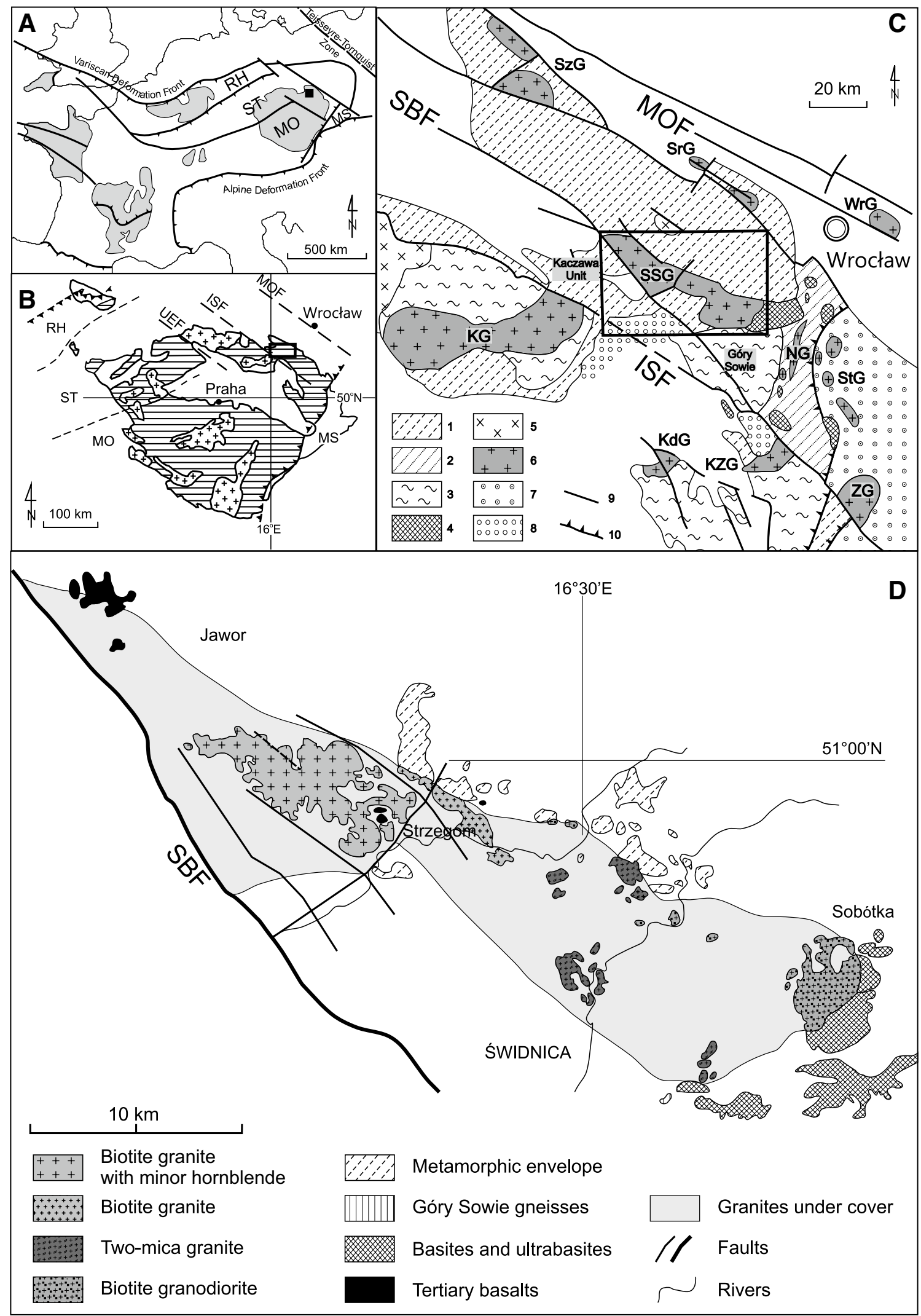


4Fig. 1 a Position of the research area in the European Variscides. Variscan massifs are shadowed. b Position of the research area in the Bohemian Massif. Major granitoid intrusions are indicated by crosses. c Variscan granitoids in the Sudetic fragment of the Bohemian Massif (compilation with modifications after Aleksandrowski et al. 1997; Mazur et al. 2006; Oberc-Dziedzic et al. 2013). The Strzegom-Sobótka Massif is indicated by a black rectangle. Symbols: 1-low-grade metamorphic rocks; 2-mylonites; 3-gneisses; 4-mafites and ultramafites of the Central Sudetic Ophiolite; 5Cadomian granitoids; 6-Variscan granitoids; 7-Moravo-Silesian metaigneous and metasedimentary rocks; 8-molasse; 9-faults; 10 - thrusts; d Geological sketch map of the Strzegom-Sobótka massif (after Majerowicz 1972; Puziewicz 1990; modified). ISF IntraSudetic fault, $K d G$ Kudowa granite, $K G$ Karkonosze granite, $K Z G$ Kłodzko-Złoty Stok granite, $M O$ Moldanubian zone, $M O F$ Middle Odra fault, $M S$ Moravo-Silesian zone, $N G$ Niemcza granitoid, $R H$ Rhenohercynian zone, $\operatorname{SrG}$ Środa Śląska granite, SSG StrzegomSobótka granite, $S t G$ Strzelin granite, $S T$ Saxothuringian zone, $S z G$ Szprotawa granite, $U E F$ Upper Elbe fault, $W r G$ Wrocław granite, $Z G$ Žulová granite

The chemical compositions of minerals were investigated using a Cameca SX-100 electron microprobe (WDS mode) in the Electron Microprobe Laboratory at the Inter-Institute Microanalytical Complex for Minerals and Synthetic Substances, Warsaw University, Poland. The following instrumental conditions were applied: a counting time of 10-20 s; an acceleration voltage of $15 \mathrm{kV}$ and a beam current of $20 \mathrm{nA}$ for major elements and those of $20-30 \mathrm{kV}$ and $50 \mathrm{nA}$ for trace elements. The following standards were used: albite (Na); diopside ( $\mathrm{Mg}, \mathrm{Si}, \mathrm{Ca}$ ); wollastonite $(\mathrm{Si}, \mathrm{Ca})$; orthoclase $(\mathrm{K}, \mathrm{Al})$; haematite $(\mathrm{Fe})$; rhodochrosite $(\mathrm{Mn})$; apatite $(\mathrm{P}, \mathrm{F})$; phlogopite $(\mathrm{F})$; barite $(\mathrm{S}, \mathrm{Ba})$; rutile $(\mathrm{Ti})$; zircon $(\mathrm{Zr})$; synthetic strontium titanite (Sr); YAG $(\mathrm{Y})$; synthetic lanthanum hexaboride, $\mathrm{LaB}_{6}(\mathrm{La})$; synthetic cerium(III) ultraphosphate, $\mathrm{CeP}_{5} \mathrm{O}_{14}(\mathrm{Ce})$; synthetic neodymium gallate, $\mathrm{NdGaO}_{3}(\mathrm{Nd})$; synthetic chromium(III) oxide, $\mathrm{Cr}_{2} \mathrm{O}_{3}(\mathrm{Cr})$; synthetic $\mathrm{NiO}$ (Ni) and tugtupite $(\mathrm{Cl})$. The typical spot size ranged between 2 and $5 \mu \mathrm{m}$ depending on the analyzed mineral. Matrix correction was performed using the standard PAP procedure.

Feldspar and biotite formulae were recalculated on the basis of 8 and 11 oxygens, respectively. Although $\mathrm{Fe}^{2+} / \mathrm{Fe}^{3+}$ ratios in biotite have been estimated by Wichrowska (1974, 1977) and Puziewicz (1994, 1995), their sampling does not overlap with ours. Therefore, we decided to treat all $\mathrm{Fe}$ as $\mathrm{Fe}^{2+}$. The amphibole formulae and estimated $\mathrm{Fe}^{2+} / \mathrm{Fe}^{3+}$ ratios were calculated using the procedure of Locock (2014) and following the current nomenclature of IMA (Hawthorne et al. 2012). OH contents were estimated using the equation $\mathrm{OH}=2$-Ti. For most analyses, the average cation contents were obtained from normalizations to 15 ( $\Sigma$ cations from $\mathrm{Si}$ to $\mathrm{Ca}=15 \mathrm{apfu}$ ). In several cases, when the sum of the C-site cations was too low, the normalization to 13 ( $\Sigma$ cations from $\mathrm{Si}$ to $\mathrm{Mg}=13 \mathrm{apfu}$ ) was chosen. Apatite analyses were recalculated on the basis of 8 cations. Allanite formulae were recalculated by setting the total of the T- and M-site cations equal to 6 and adjusting the $\mathrm{Fe}^{3+} / \mathrm{Fe}^{2+}$ ratio to obtain a total of 25 negative charges (Ercit 2002).

The samples used for geochemical and isotopic analyses were selected based on thin section analyses. Approximately, $0.5-1.0 \mathrm{~kg}$ of each sample was crushed and quartered, and $100 \mathrm{~g}$ of each rock was milled into powder. Whole-rock major and trace element analyses were performed at the ACME Analytical Laboratories in Vancouver (Canada). Major oxide and trace element compositions were determined by ICP-ES (inductively coupled plasma emission spectrometry). Trace elements were analyzed by ICP-MS (inductively coupled plasma mass spectrometry), according to procedures described on http://acmelab.com. All analyses were calculated on an anhydrous basis, with iron expressed as $\mathrm{Fe}_{2} \mathrm{O}_{3}(t)=\mathrm{Fe}_{2} \mathrm{O}_{3}(t)+1.111 \mathrm{FeO}$.

$\mathrm{Rb} / \mathrm{Sr}$ and $\mathrm{Sm} / \mathrm{Nd}$ isotopic analyses were performed on $100 \mathrm{mg}$ of powdered samples at the Institute of Geological Sciences of the Polish Academy of Sciences, Warsaw (Poland) using a VG Sector 54 mass spectrometer operating in multi-collector dynamic mode. ${ }^{87} \mathrm{Sr} /{ }^{86} \mathrm{Sr}$ ratios were normalized to ${ }^{86} \mathrm{Sr} /{ }^{88} \mathrm{Sr}=0.1184$, whereas ${ }^{143} \mathrm{Nd} /{ }^{144} \mathrm{Nd}$ ratios were normalized to ${ }^{146} \mathrm{Nd} /{ }^{144} \mathrm{Nd}=0.7219$. The standard reference materials of NBS SRM 987 and JNdi-1 were used, which yielded a mean ${ }^{87} \mathrm{Sr} /{ }^{86} \mathrm{Sr}$ value of $0.710252 \pm 18$ $(2 \sigma)$ and a mean ${ }^{143} \mathrm{Nd} /{ }^{144} \mathrm{Nd}$ value of $0.512095 \pm 13(2 \sigma)$, respectively. Time-related calculations used values of ${ }^{143} \mathrm{Nd} /{ }^{144} \mathrm{Nd}=0.512638$ and ${ }^{147} \mathrm{Sm} /{ }^{144} \mathrm{Nd}=0.1967$ for the present-day depleted mantle following the radiogenic linear growth of the mantle with $\varepsilon \mathrm{Nd}=0$ at $4.568 \mathrm{Ga}$. Epsilon values at time $T$ were calculated using the following relation:

$\varepsilon_{\mathrm{T}} \mathrm{Nd}=\left[\left({ }^{143} \mathrm{Nd} /{ }^{144} \mathrm{Nd}_{\text {sample }} /{ }^{143} \mathrm{Nd} /{ }^{144} \mathrm{Nd}_{\text {TCHUR }}\right)\right.$ $-1] \times 10,000$, where CHUR is the chondrite uniform reservoir and $T$ is generally the time the rock was formed. Depleted mantle model ages are calculated assuming a modern upper mantle with values of ${ }^{147} \mathrm{Sm} /{ }^{144} \mathrm{Nd}=0.2137$ and ${ }^{143} \mathrm{Nd} /{ }^{144} \mathrm{Nd}=0.51315$.

Rock-mineral data were used in the geochemical modelling performed with the GENESIS software of Teixeira (1996). Isotopic data were processed using the ISOPLOT/ EX ver. 2.4 software of Ludwig (2000).

\section{Petrography}

\section{Hornblende-biotite granite (HBG)}

The studied granite is a medium- to coarse-grained grey rock that is hypidiomorphic and equigranular to porphyritic in texture and typically exhibits non-oriented fabric. The phenocrysts are mostly K-feldspar and sometimes plagioclase. This granite is modally classified as a monzogranite and is composed of approximately $24-45 \%$ plagioclase, $21-44 \%$ K-feldspar, $17-38 \%$ quartz and 1-12\% biotite, with 
Table 1 Major and trace element analyses of the HBG

\begin{tabular}{|c|c|c|c|c|c|c|c|c|c|c|c|c|}
\hline Sample & 009 & 010 & 013 & 015 & 028 & 032 & 034 & 036 & 039 & 045 & 051 & 058 \\
\hline Locality & 1 & 1 & 1 & 1 & 1 & 2 & 2 & 2 & 3 & 4 & 5 & 5 \\
\hline \multicolumn{13}{|l|}{ wt. $\%$} \\
\hline $\mathrm{SiO}_{2}$ & 72.99 & 72.49 & 71.89 & 72.38 & 73.15 & 73.20 & 72.30 & 70.66 & 72.01 & 73.19 & 72.27 & 70.13 \\
\hline $\mathrm{TiO}_{2}$ & 0.28 & 0.26 & 0.26 & 0.27 & 0.22 & 0.20 & 0.20 & 0.30 & 0.34 & 0.29 & 0.26 & 0.34 \\
\hline $\mathrm{Al}_{2} \mathrm{O}_{3}$ & 13.30 & 13.68 & 13.94 & 13.78 & 13.30 & 13.33 & 13.57 & 13.99 & 13.89 & 13.09 & 13.56 & 14.14 \\
\hline $\mathrm{Fe}_{2} \mathrm{O}_{3} t$ & 2.85 & 2.57 & 2.63 & 2.80 & 2.27 & 2.09 & 1.48 & 2.72 & 2.54 & 2.83 & 2.71 & 3.10 \\
\hline $\mathrm{MnO}$ & 0.05 & 0.05 & 0.05 & 0.06 & 0.05 & 0.05 & 0.03 & 0.05 & 0.05 & 0.05 & 0.06 & 0.07 \\
\hline $\mathrm{MgO}$ & 0.30 & 0.27 & 0.28 & 0.29 & 0.21 & 0.22 & 0.29 & 0.38 & 0.54 & 0.33 & 0.27 & 0.41 \\
\hline $\mathrm{CaO}$ & 1.42 & 1.39 & 1.31 & 1.40 & 1.21 & 1.26 & 1.41 & 1.39 & 1.94 & 1.40 & 1.39 & 1.54 \\
\hline $\mathrm{Na}_{2} \mathrm{O}$ & 3.70 & 3.68 & 3.52 & 3.64 & 3.41 & 3.20 & 3.18 & 3.46 & 3.28 & 3.46 & 3.61 & 3.80 \\
\hline $\mathrm{K}_{2} \mathrm{O}$ & 4.20 & 4.89 & 5.33 & 4.85 & 5.00 & 4.78 & 4.83 & 4.87 & 4.43 & 4.52 & 4.48 & 4.44 \\
\hline $\mathrm{P}_{2} \mathrm{O}_{5}$ & 0.07 & 0.06 & 0.07 & 0.08 & 0.05 & 0.05 & 0.06 & 0.11 & 0.11 & 0.08 & 0.07 & 0.10 \\
\hline LOI & 0.19 & 0.25 & 0.33 & 0.43 & 0.26 & 1.10 & 1.68 & 0.44 & 0.47 & 0.23 & 0.26 & 0.74 \\
\hline Total & 99.46 & 99.70 & 99.76 & 100.10 & 99.24 & 99.48 & 99.15 & 98.51 & 99.71 & 99.58 & 99.08 & 98.94 \\
\hline $\mathrm{A} / \mathrm{CNK}$ & 1.01 & 0.99 & 1.00 & 1.00 & 1.01 & 1.05 & 1.04 & 1.04 & 1.01 & 1.00 & 1.02 & 1.02 \\
\hline Mg no. & 0.17 & 0.17 & 0.17 & 0.17 & 0.15 & 0.17 & 0.28 & 0.22 & 0.30 & 0.19 & 0.16 & 0.21 \\
\hline \multicolumn{13}{|l|}{ ppm } \\
\hline $\mathrm{Ba}$ & 366.1 & 518.5 & 657.6 & 596.0 & 539.9 & 432.4 & 602.0 & 692.8 & 518.6 & 491.4 & 559.0 & 572.8 \\
\hline $\mathrm{Cs}$ & 4.1 & 3.8 & 4.4 & 4.3 & 3.6 & 4.4 & 5.8 & 5.9 & 3.3 & 4.7 & 5.5 & 3.1 \\
\hline $\mathrm{Rb}$ & 173.6 & 205.1 & 211.0 & 191.4 & 192.7 & 182.4 & 226.2 & 208.5 & 148.1 & 185.7 & 199.8 & 217.7 \\
\hline $\mathrm{Sr}$ & 76.7 & 86.0 & 90.8 & 94.2 & 79.8 & 74.9 & 126.5 & 115.9 & 149.8 & 87.0 & 93.7 & 112.0 \\
\hline V & 21.0 & 15.0 & 12.0 & 12.0 & 16.0 & 11.0 & 13.0 & 23.0 & 27.0 & 14.0 & 12.0 & 16.0 \\
\hline Co & 5.3 & 2.3 & 2.3 & 2.4 & 2.8 & 1.8 & 2.3 & 4.6 & 3.7 & 3.4 & 3.7 & 3.6 \\
\hline $\mathrm{Zr}$ & 294.1 & 246.0 & 231.3 & 257.0 & 189.8 & 179.2 & 162.4 & 223.8 & 200.2 & 231.7 & 279.3 & 220.7 \\
\hline $\mathrm{Hf}$ & 7.9 & 7.0 & 6.8 & 6.5 & 5.5 & 5.3 & 5.0 & 5.9 & 5.4 & 6.9 & 7.7 & 5.9 \\
\hline $\mathrm{Y}$ & 36.6 & 41.5 & 37.9 & 35.1 & 31.9 & 34.8 & 21.2 & 38.0 & 25.0 & 36.0 & 38.6 & 36.6 \\
\hline $\mathrm{Nb}$ & 27.0 & 24.9 & 24.1 & 23.9 & 19.5 & 19.1 & 14.7 & 23.3 & 19.5 & 23.9 & 23.4 & 22.8 \\
\hline $\mathrm{Ta}$ & 2.1 & 1.6 & 1.6 & 2.0 & 1.6 & 2.1 & 1.9 & 2.3 & 1.7 & 2.2 & 2.3 & 2.1 \\
\hline $\mathrm{U}$ & 7.2 & 7.5 & 5.4 & 9.5 & 5.4 & 5.2 & 3.3 & 4.7 & 2.4 & 6.6 & 6.1 & 14.6 \\
\hline Th & 28.4 & 27.0 & 21.0 & 22.5 & 15.5 & 16.9 & 18.3 & 13.7 & 20.4 & 23.1 & 23.3 & 18.5 \\
\hline $\mathrm{La}$ & 69.5 & 62.8 & 55.0 & 54.6 & 41.5 & 33.5 & 47.0 & 47.9 & 52.4 & 54.0 & 62.7 & 39.7 \\
\hline $\mathrm{Ce}$ & 129.9 & 114.5 & 99.8 & 110.0 & 80.2 & 66.9 & 95.1 & 90.3 & 99.7 & 100.8 & 120.0 & 78.6 \\
\hline $\operatorname{Pr}$ & 13.3 & 12.8 & 11.2 & 11.9 & 8.4 & 7.7 & 9.4 & 9.4 & 10.5 & 10.8 & 12.6 & 8.7 \\
\hline $\mathrm{Nd}$ & 46.6 & 45.2 & 39.5 & 42.0 & 31.9 & 30.7 & 34.1 & 35.7 & 36.3 & 39.0 & 44.7 & 31.8 \\
\hline $\mathrm{Sm}$ & 8.4 & 8.0 & 7.0 & 7.2 & 6.5 & 6.1 & 5.7 & 6.6 & 7.1 & 7.4 & 8.7 & 5.8 \\
\hline $\mathrm{Eu}$ & 0.9 & 0.9 & 1.0 & 0.9 & 0.9 & 0.8 & 0.9 & 1.2 & 1.0 & 1.0 & 1.0 & 0.9 \\
\hline $\mathrm{Gd}$ & 6.9 & 6.5 & 5.9 & 6.7 & 5.4 & 5.1 & 5.0 & 5.9 & 5.8 & 6.4 & 6.7 & 5.9 \\
\hline $\mathrm{Tb}$ & 1.2 & 1.2 & 1.0 & 1.0 & 1.0 & 1.0 & 0.8 & 1.1 & 1.0 & 1.2 & 1.2 & 1.0 \\
\hline Dy & 5.2 & 7.0 & 5.7 & 5.9 & 4.9 & 5.8 & 4.0 & 5.6 & 4.5 & 5.3 & 5.7 & 5.9 \\
\hline Ho & 1.2 & 1.3 & 1.2 & 1.2 & 1.0 & 1.2 & 0.8 & 1.2 & 0.9 & 1.2 & 1.3 & 1.1 \\
\hline Er & 3.3 & 3.6 & 3.3 & 3.4 & 3.0 & 3.3 & 2.5 & 3.3 & 2.2 & 3.4 & 3.6 & 3.3 \\
\hline $\mathrm{Tm}$ & 0.5 & 0.6 & 0.5 & 0.5 & 0.4 & 0.5 & 0.3 & 0.6 & 0.3 & 0.5 & 0.6 & 0.5 \\
\hline $\mathrm{Yb}$ & 3.8 & 4.2 & 3.5 & 3.6 & 3.0 & 3.4 & 2.2 & 3.6 & 1.8 & 3.5 & 3.6 & 3.4 \\
\hline $\mathrm{Lu}$ & 0.5 & 0.6 & 0.5 & 0.6 & 0.4 & 0.5 & 0.3 & 0.5 & 0.3 & 0.5 & 0.5 & 0.5 \\
\hline$(\mathrm{La} / \mathrm{Yb})_{\mathrm{N}}$ & 12.1 & 10.0 & 10.4 & 10.2 & 9.3 & 6.7 & 14.5 & 8.9 & 19.3 & 10.4 & 11.8 & 7.8 \\
\hline $\mathrm{Eu} / \mathrm{Eu}^{*}$ & 0.4 & 0.4 & 0.5 & 0.4 & 0.5 & 0.4 & 0.5 & 0.6 & 0.5 & 0.4 & 0.4 & 0.5 \\
\hline
\end{tabular}


Table 1 (continued)

\begin{tabular}{|c|c|c|c|c|c|c|c|c|c|c|c|c|}
\hline Sample & 060 & 065 & 066 & 067 & 080 & 082 & 085 & 087 & 102 & 107 & 138 & 140 \\
\hline Locality & 6 & 7 & 7 & 7 & 8 & 8 & 8 & 8 & 4 & 4 & 3 & 3 \\
\hline \multicolumn{13}{|l|}{ wt. $\%$} \\
\hline $\mathrm{SiO}_{2}$ & 72.34 & 71.70 & 74.98 & 68.03 & 73.63 & 72.36 & 73.32 & 72.81 & 72.09 & 74.34 & 71.30 & 73.20 \\
\hline $\mathrm{TiO}_{2}$ & 0.25 & 0.25 & 0.14 & 0.59 & 0.16 & 0.21 & 0.23 & 0.23 & 0.29 & 0.17 & 0.36 & 0.20 \\
\hline $\mathrm{Al}_{2} \mathrm{O}_{3}$ & 13.76 & 13.91 & 13.18 & 14.09 & 13.52 & 13.87 & 13.76 & 13.47 & 13.70 & 13.21 & 13.89 & 13.77 \\
\hline $\mathrm{Fe}_{2} \mathrm{O}_{3} t$ & 2.34 & 2.52 & 1.48 & 5.31 & 1.74 & 2.23 & 2.33 & 2.53 & 2.72 & 1.74 & 2.99 & 1.31 \\
\hline $\mathrm{MnO}$ & 0.04 & 0.05 & 0.04 & 0.10 & 0.04 & 0.06 & 0.04 & 0.08 & 0.05 & 0.04 & 0.05 & 0.02 \\
\hline $\mathrm{MgO}$ & 0.28 & 0.30 & 0.19 & 0.62 & 0.24 & 0.25 & 0.24 & 0.25 & 0.33 & 0.21 & 0.44 & 0.27 \\
\hline $\mathrm{CaO}$ & 1.29 & 1.31 & 1.04 & 1.88 & 1.38 & 1.29 & 1.04 & 1.28 & 1.45 & 1.16 & 1.66 & 1.51 \\
\hline $\mathrm{Na}_{2} \mathrm{O}$ & 3.59 & 3.63 & 3.50 & 3.81 & 3.37 & 3.48 & 3.42 & 3.35 & 3.59 & 3.56 & 3.47 & 3.21 \\
\hline $\mathrm{K}_{2} \mathrm{O}$ & 4.82 & 4.56 & 4.57 & 3.98 & 4.60 & 5.08 & 5.15 & 4.88 & 4.70 & 4.49 & 4.12 & 4.61 \\
\hline $\mathrm{P}_{2} \mathrm{O}_{5}$ & 0.06 & 0.10 & 0.04 & 0.15 & 0.04 & 0.05 & 0.06 & 0.06 & 0.08 & 0.05 & 0.12 & 0.06 \\
\hline LOI & 0.32 & 0.33 & 0.32 & 0.26 & 0.39 & 0.28 & 0.39 & 0.24 & 0.28 & 0.36 & 1.10 & 1.30 \\
\hline Total & 99.21 & 98.78 & 99.57 & 98.97 & 99.24 & 99.28 & 99.59 & 99.32 & 99.41 & 99.44 & 99.49 & 99.46 \\
\hline A/CNK & 1.02 & 1.05 & 1.05 & 1.01 & 1.04 & 1.02 & 1.05 & 1.03 & 1.01 & 1.03 & 1.05 & 1.06 \\
\hline Mg no. & 0.19 & 0.19 & 0.20 & 0.19 & 0.21 & 0.18 & 0.17 & 0.16 & 0.19 & 0.19 & 0.23 & 0.29 \\
\hline \multicolumn{13}{|l|}{ ppm } \\
\hline $\mathrm{Ba}$ & 593.7 & 506.4 & 379.1 & 255.4 & 630.6 & 594.9 & 837.0 & 601.1 & 560.3 & 415.0 & 403.0 & 551.8 \\
\hline $\mathrm{Cs}$ & 3.4 & 14.8 & 9.4 & 6.0 & 5.8 & 5.0 & 2.8 & 5.5 & 5.2 & 12.5 & 6.6 & 5.2 \\
\hline $\mathrm{Rb}$ & 195.9 & 257.0 & 232.2 & 203.0 & 210.3 & 201.4 & 194.7 & 219.1 & 184.8 & 232.4 & 192.4 & 215.2 \\
\hline $\mathrm{Sr}$ & 89.3 & 83.4 & 58.6 & 85.3 & 85.7 & 87.1 & 97.2 & 99.1 & 92.3 & 68.6 & 97.8 & 118.1 \\
\hline V & 11.0 & 11.0 & 0.0 & 22.0 & 0.0 & 9.0 & 11.0 & 9.0 & 14.0 & $<8$ & 18.0 & 11.0 \\
\hline $\mathrm{Co}$ & 2.7 & 3.4 & 1.8 & 7.1 & 2.0 & 2.1 & 1.6 & 4.8 & 3.4 & 1.9 & 3.4 & 1.6 \\
\hline $\mathrm{Zr}$ & 265.3 & 210.4 & 97.6 & 395.3 & 136.9 & 185.2 & 215.2 & 187.0 & 230.0 & 148.8 & 266.2 & 139.2 \\
\hline Hf & 7.1 & 6.1 & 3.8 & 11.1 & 3.7 & 5.3 & 6.0 & 5.7 & 6.7 & 5.1 & 7.3 & 4.4 \\
\hline $\mathrm{Y}$ & 40.4 & 32.3 & 33.7 & 47.0 & 25.8 & 33.6 & 38.1 & 29.8 & 40.2 & 34.3 & 39.2 & 23.8 \\
\hline $\mathrm{Nb}$ & 24.5 & 22.3 & 15.9 & 34.5 & 14.1 & 19.9 & 24.7 & 19.7 & 24.8 & 21.5 & 23.5 & 15.1 \\
\hline $\mathrm{Ta}$ & 2.2 & 2.6 & 2.8 & 2.6 & 1.0 & 2.1 & 2.7 & 1.6 & 2.2 & 3.9 & 2.7 & 1.6 \\
\hline $\mathrm{U}$ & 6.3 & 10.3 & 11.9 & 6.3 & 7.4 & 6.1 & 9.2 & 4.5 & 7.8 & 14.3 & 3.7 & 3.4 \\
\hline $\mathrm{Th}$ & 22.8 & 15.3 & 20.8 & 33.8 & 30.7 & 15.7 & 21.3 & 16.0 & 19.6 & 22.2 & 15.9 & 18.3 \\
\hline $\mathrm{La}$ & 49.8 & 41.5 & 30.7 & 92.8 & 32.4 & 39.2 & 42.5 & 45.1 & 55.8 & 35.1 & 41.8 & 49.7 \\
\hline $\mathrm{Ce}$ & 96.5 & 82.6 & 62.6 & 185.4 & 62.0 & 74.6 & 87.3 & 89.9 & 103.1 & 65.9 & 79.8 & 91.0 \\
\hline $\operatorname{Pr}$ & 10.1 & 8.8 & 6.8 & 19.7 & 6.6 & 8.1 & 9.7 & 9.8 & 10.8 & 7.5 & 8.9 & 10.0 \\
\hline $\mathrm{Nd}$ & 38.8 & 31.9 & 24.6 & 67.8 & 24.8 & 28.7 & 33.0 & 35.4 & 37.5 & 27.1 & 34.8 & 35.7 \\
\hline $\mathrm{Sm}$ & 7.3 & 5.7 & 4.7 & 10.3 & 4.9 & 6.7 & 6.9 & 5.8 & 7.9 & 5.4 & 6.6 & 6.6 \\
\hline $\mathrm{Eu}$ & 1.0 & 0.9 & 0.4 & 0.9 & 0.6 & 1.0 & 0.8 & 1.0 & 1.0 & 0.6 & 1.0 & 0.8 \\
\hline $\mathrm{Gd}$ & 6.3 & 4.8 & 4.2 & 7.9 & 4.2 & 5.6 & 7.1 & 4.9 & 6.9 & 5.5 & 5.6 & 4.8 \\
\hline $\mathrm{Tb}$ & 1.2 & 0.9 & 0.9 & 1.4 & 0.8 & 1.0 & 1.1 & 0.9 & 1.2 & 0.9 & 1.1 & 0.8 \\
\hline Dy & 5.5 & 4.8 & 5.6 & 7.5 & 3.9 & 5.0 & 6.8 & 4.8 & 5.7 & 6.0 & 6.0 & 4.0 \\
\hline Ho & 1.2 & 1.1 & 0.9 & 1.4 & 0.8 & 1.0 & 1.4 & 0.9 & 1.3 & 1.2 & 1.3 & 0.8 \\
\hline $\mathrm{Er}$ & 3.5 & 2.9 & 3.0 & 4.0 & 2.4 & 2.9 & 4.1 & 2.5 & 3.5 & 3.7 & 3.7 & 2.1 \\
\hline $\mathrm{Tm}$ & 0.6 & 0.4 & 0.4 & 0.6 & 0.4 & 0.5 & 0.6 & 0.4 & 0.6 & 0.5 & 0.6 & 0.3 \\
\hline $\mathrm{Yb}$ & 3.6 & 3.0 & 3.0 & 4.3 & 2.3 & 3.1 & 4.3 & 2.6 & 3.9 & 3.7 & 3.8 & 2.0 \\
\hline $\mathrm{Lu}$ & 0.5 & 0.4 & 0.5 & 0.7 & 0.3 & 0.5 & 0.6 & 0.4 & 0.5 & 0.5 & 0.5 & 0.3 \\
\hline$(\mathrm{La} / \mathrm{Yb})_{\mathrm{N}}$ & 9.1 & 9.4 & 6.8 & 14.6 & 9.3 & 8.4 & 6.6 & 11.8 & 9.6 & 6.4 & 7.3 & 16.5 \\
\hline $\mathrm{Eu} / \mathrm{Eu}^{*}$ & 0.5 & 0.5 & 0.3 & 0.3 & & & & & & & & \\
\hline
\end{tabular}

LOI loss on ignition, $A / C N K \mathrm{Al}_{2} \mathrm{O}_{3} /\left(\mathrm{CaO}+\mathrm{NaO}+\mathrm{K}_{2} \mathrm{O}\right)$ molar, $M g$ no. atomic $\mathrm{Mg} /(\mathrm{Mg}+\mathrm{Fe}), E u / E u^{*}\left[\mathrm{Eu}_{\mathrm{N}} / \sqrt{ }\left(\mathrm{Sm}_{\mathrm{N} \times} \mathrm{Gd}_{\mathrm{N}}\right)\right], N$ chondrite normalized to values of Nakamura (1974)

Locality: 1-Strzegom, 2-Goczałków, 3-Wieśnica, 4-Kostrza, 5-Gniewków, 6-Czernica, 7-Zimnik, 8-Rogoźnica, 9-Paszowice, 10-Borów 
amphibole as a minor constituent; in places, the amphibole content slightly exceeds 3\% (Majerowicz 1972). There are no sharp contacts between the porphyritic and equigranular facies, and this transition appears to be gradational. Minor muscovite is present locally. Accessory minerals include apatite, zircon, allanite, titanite and rutile (Majerowicz 1972; Turniak et al. 2007). Alteration effects, such as albitization of feldspars and chloritization of biotite, are moderate, although they may be locally intensive. Aplitic and pegmatitic dikes and irregular streaks are common, and miarolitic pegmatites of the MI-REE (miarolitic-rare-earth-element) subclass and NYF (niobium-yttrium-fluorine) affiliation, which range from centimetres to several metres in size, are locally abundant (e.g., Puziewicz 1985; Janeczek 2007; Pieczka et al. 2015).

The HBG also contains country-rock xenoliths and mafic enclaves (Majerowicz 1972; Maciejewski and Morawski 1975; Domańska 1984; Domańska and Słaby 2004; Domańska-Siuda and Słaby 2005). Detailed descriptions of all the relevant field and petrographic
Fig. 2 Field photographs of rock textures: a dioritic enclaves with progressive hybridization zone (indicated by dotted lines); b composite enclave rimmed by felsic halo; $\mathbf{c}$ hybridization zone; inside mafic body visible numerous plagioclase xenocrysts; $\mathbf{d}$ numerous mafic enclaves occurring within the pegmatite; $\mathbf{e}$ enclaves of different composition; $\mathbf{f}$ plagioclase crystal crosses the border enclave-granite and a large crystal of feldspar within the enclave. $K f s$ K-feldspar, $P l g$ plagioclase
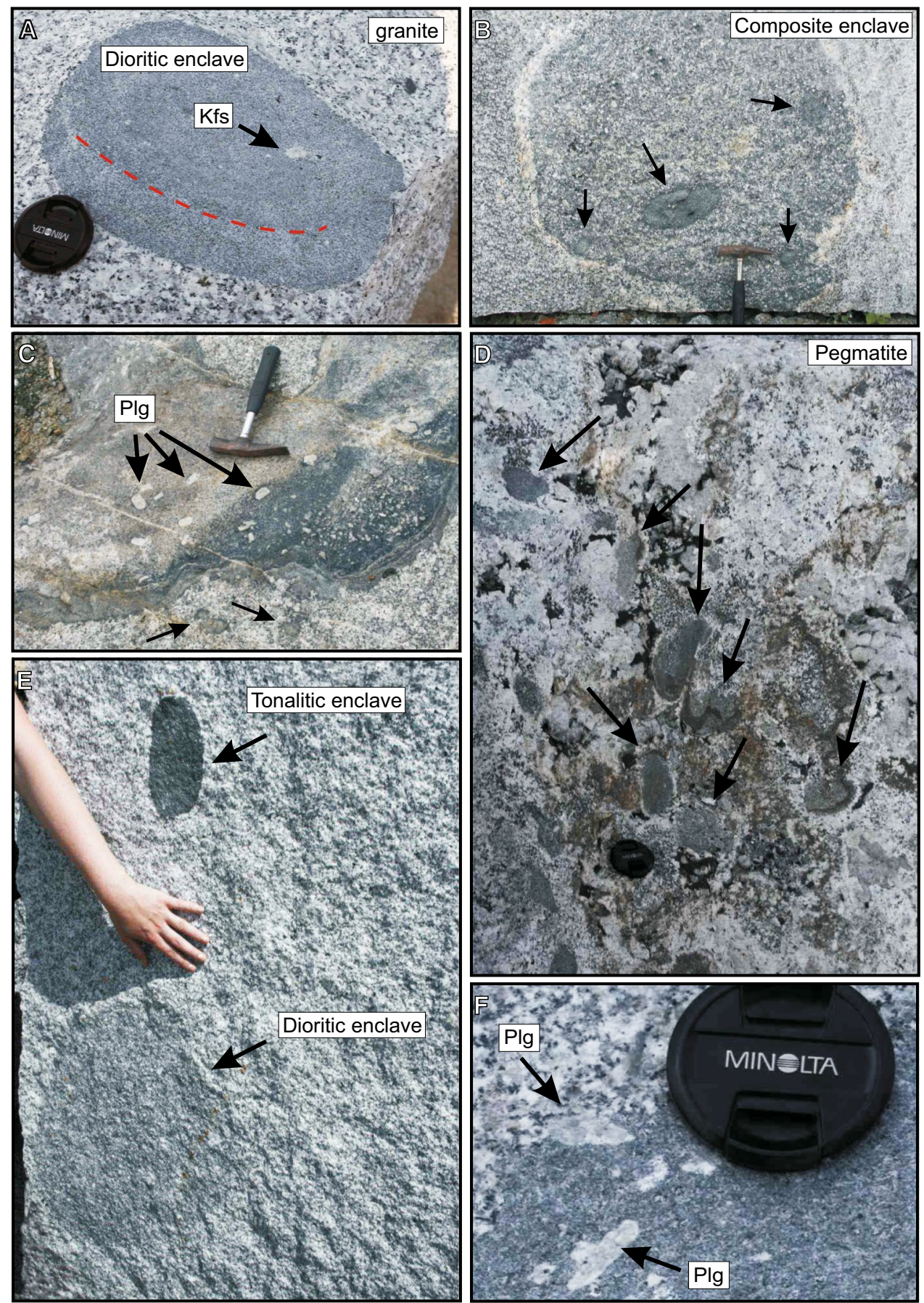
features of the HBG rocks can be found in previous works (Kural and Morawski 1968; Majerowicz 1972; Maciejewski and Morawski 1975).

\section{Mafic magmatic enclaves (MMEs)}

Mafic magmatic enclaves (MMEs) sensu Barbarin (1988) are relatively uniformly distributed in the granitic host and exhibit compositions ranging from monzonite, monzodiorite, granodiorite to tonalite. These MMEs range in size from a few centimetres to over a metre (Fig. 2a-f). The enclaves with diameters up to $10 \mathrm{~cm}$ are generally dark grey (Fig. 2e) and fine-grained, whereas larger enclaves are lighter in colour and have relatively coarse-grained textures (Fig. 2a, b, e). MMEs show non-oriented textures; they are typically equigranular but occasionally contain 1 - to 2 -cm-long feldspar phenocrysts (Figs. 2a, f, 3a, d, e, 4c-e). The spherical to ellipsoidal shapes of MMEs and the common presence of fine-grained chilled margins and sharp or partly diffuse lobate to crenulated contacts suggest that they are quenched blobs of silica-poor magma that intruded the granitic host (Fig. 2a, b, e) (Didier and Barbarin 1991; Barbarin and
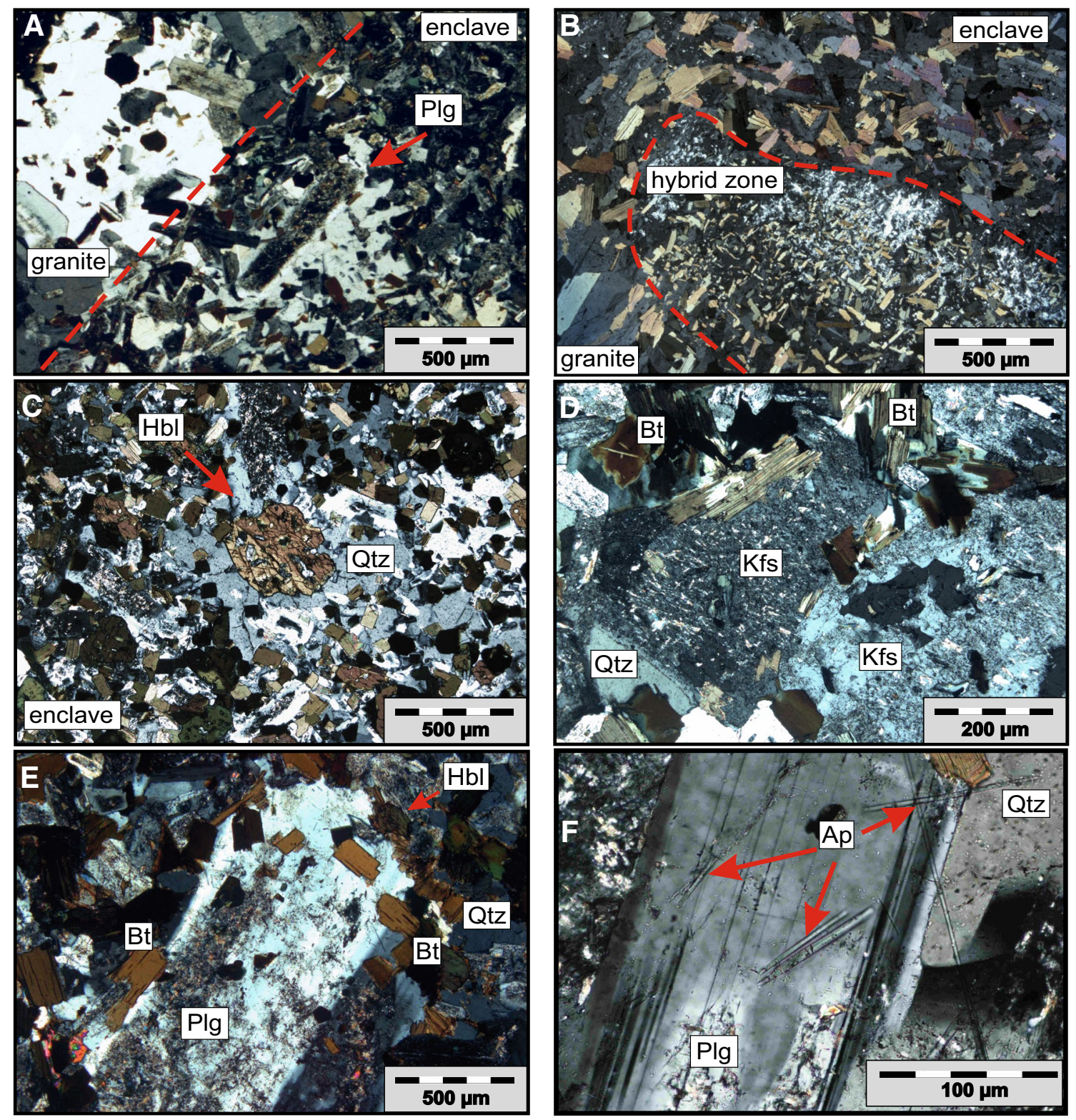

Fig. 3 Microphotographs showing textures of enclaves: a the boundary between granite and enclave; inside enclave visible large plagioclase xenocryst; $\mathbf{b}$ hybrid zone between granite and enclave; $\mathbf{c}$ automorphic crystal of hornblende inside enclave; $\mathbf{d}$ K-feldspar xenocryst

inside enclave; e large, zoned plagioclase xenocryst with biotite inclusion within enclave; $\mathbf{f}$ needle-like apatite morphology. All photographs taken under crossed nicols. $A p$ apatite, $B t$ biotite, $H b l$ hornblende, $K f s$ K-feldspar, $P l g$ plagioclase, $Q t z$ quartz 
Fig. 4 CL images of: a miarole filled by quartz aggregates; $\mathbf{b}$ zoned plagioclase xenocryst within enclave showing different luminescence than matrix plagioclase; c plagioclase crystals from the contact between granite and enclave showing different luminescence in the core and identical in the rim (indicated by the yellow arrow); d zoned plagioclase xenocryst within enclave showing different luminescence than matrix plagioclase; e zoned K-feldspar xenocrysts; f two morphology types of apatite: prismatic and zoned, forming inclusions in plagioclase xenocrysts and acicular one. $A p$ apatite, $B t$ biotite, $K f s$ K-feldspar, $P l g$ plagioclase, $Q t z$ quartz
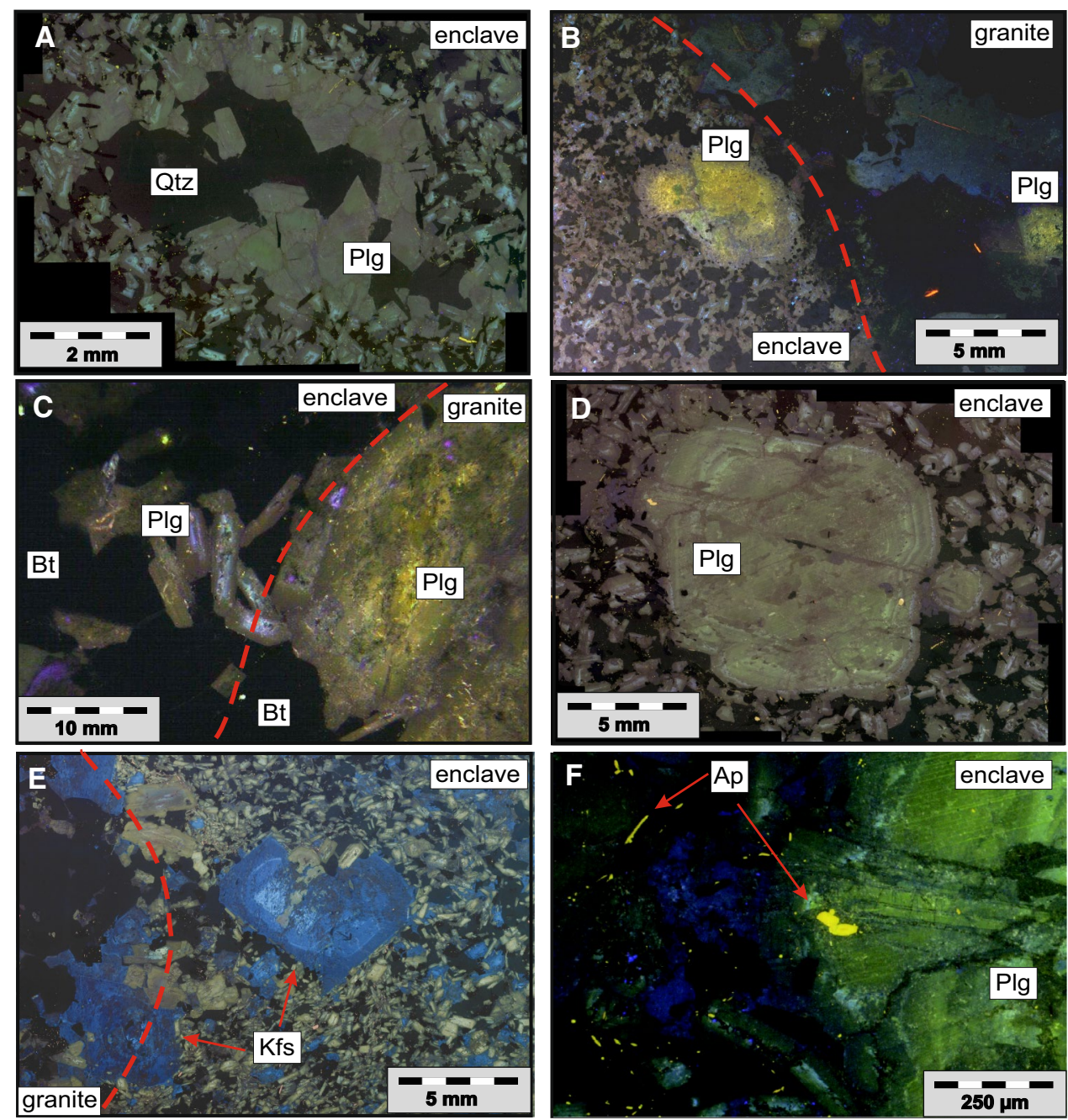

Didier 1992; Wiebe and Collins 1998). Sharp contacts are frequently observed for the smallest, darkest enclaves, which exhibit finer grained textures (Fig. 2e). However, even the contacts that appear sharp in hand specimens show interlocking textures under the microscope (Figs. 3a, 4b, c). Large feldspar phenocrysts are occasionally observed to cross the contacts between MMEs and HBG (Fig. 2f), in addition to occurring inside enclaves (Figs. 2a, f, 3a, d, e, 4b, $\mathrm{d}, \mathrm{e}, \mathrm{f})$. MMEs are commonly surrounded by narrow felsic halos of the adjacent granite that are enriched in quartz and K-feldspar; these halos represent the so-called "bleaching" zones of Vernon (1991) (Fig. 2b). Some MMEs, particularly larger ones, are surrounded by a few centimetre-thick hybrid zones with diffuse contacts directed towards both the enclave's core and the granitic host (Figs. 2a, c, 3b). In the hybrid zone (Fig. 2c), the grain sizes of the mineral constituents and the modal compositions are transitional between those of the MME and HBG. In comparison to the enclave-free granite, the hybrid zone contains higher contents of biotite and plagioclase and lower contents of
K-feldspar and quartz. This zone, however, often contains dispersed feldspar phenocrysts. The hybrid zone also frequently shows small mafic clots detached from the cores of the enclaves and thin schlieren-like mafic bands alternating with felsic bands (Fig. 2c). Sub-angular felsic patches with granitic textures are sometimes wrapped in thin bands of biotite. These patches most likely became incorporated into the hybrid zone from the surrounding granite as semi-rigid fragments. "Composite" enclaves are texturally distinct and consist of a mafic enclave enclosed in a hybrid zone that exhibits sharp contacts with the granite and is surrounded by a "bleaching" zone (Figs. 2b, 3b). Rare examples of MMEs included in granitic pegmatite are also observed (Fig. 2d). Generally, MMEs consist of 40-65\% plagioclase, 25-30\% biotite and 0-3\% amphibole. Quartz and K-feldspar are subordinate, although their contents sporadically reach up to $5 \%$. The accessory minerals include zircon $(5-100 \mu \mathrm{m}$ long), needle-like apatite (0.1-0.5 mm in length), allanite (2-50 $\mu \mathrm{m})$, monazite (5-25 $\mu \mathrm{m}$ in diameter), and opaque phases. 


\section{Results}

\section{Mineral growth textures}

The mineral growth textures of the HBG do not differ from the descriptions published by Majerowicz (1972) and Kural and Morawski (1968). Quartz in the HBG forms interstitial grains or granular aggregates with undulose to mosaic extinction. Generally anhedral, quartz locally becomes euhedral against K-feldspar. Graphic intergrowths with K-feldspar are sometimes observed. Plagioclase in the HBG occurs as subhedral to almost euhedral prisms, up to $1.5 \mathrm{~cm}$ long, but phenocrysts replaced by chessboard albite reach up to $3 \mathrm{~cm}$. Typically, the plagioclase is a normal-zoned andesine-oligoclase with luminescence changing from green and olive-green to dull ochre from the core towards the margin. Oscillatory and patchy zoning is less common (Fig. 4d). Larger crystals show the presence of partly resorbed and altered andesine cores that are easily discernible by their bright green to bluish luminescence (Fig. 4b, c). Anhedral albitic rims with dark blue luminescence occur around plagioclase in contact with $\mathrm{K}$-feldspar.

$\mathrm{K}$-feldspar in the HBG is a perthitic microcline (Majerowicz 1972 and references therein). In the porphyritic facies, well-shaped phenocrysts up to $2-3 \mathrm{~cm}$ in size coexist with $\mathrm{K}$-feldspar in the rock groundmass. K-feldspar phenocrysts usually display oscillatory zoning emphasized by the rhythmically changing intensity of blue luminescence (Fig. 4e). The boundaries between the bands are often delineated by inclusions of plagioclase and biotite, whose longer axes are approximately parallel to the former euhedral growth faces of K-feldspar. Groundmass K-feldspar is interstitial and unzoned.

Biotite in the HBG forms separate subhedral to nearly euhedral plates, usually $2-4 \mathrm{~mm}$ in diameter, or aggregates of randomly oriented smaller crystals. Biotite displays pale straw yellow to dark brown pleochroism. Amphibole with yellowish-green to green pleochroic colours is a minor constituent of the HBG. Subhedral to nearly euhedral prisms occur separately or in association with biotite. Biotitization and/or chloritization are common alteration features, particularly along cleavage planes, fractures and margins.

Euhedral prismatic apatite forms inclusions in biotite and amphibole. Less commonly, larger and sturdier crystals, sometimes slightly zoned as shown by varying intensity of yellow luminescence, are enclosed in feldspars and quartz. Allanite occurs separately or as inclusions in biotite and amphibole. It is euhedral and prismatic and displays complex growth zoning in scanning electron microscope SEM images, with mosaic cores overgrown by oscillatory, finebanded margins. Zircon is mostly present as inclusions in biotite and amphibole and forms euhedral prismatic crystals with typical igneous zoning visible in SEM images. Ilmenite is found as inclusions in biotite. Chloritized biotite and amphibole also contain secondary titanite and epidote.

Quartz in MMEs occurs as anhedral, interstitial or poikilitic grains. Rare quartz ocelli and oval to ellipsoid 5-mm quartz aggregates with euhedral plagioclase crystals projecting from the margins inwards are observed in some MMEs. The latter structures have been interpreted as voids left after the degassing of mafic magma and filled with quartz from granitic melt (e.g., Vernon 1991, 2010). The occurrence of miaroles in MMEs is evidence of the magmatic origin of the enclaves (Fig. 4a) (Vernon 1991, 2010).

Plagioclase from the MME matrix forms euhedral to subhedral laths or strongly elongated tabular crystals that are up to $1 \mathrm{~mm}$ in size. This plagioclase is usually normally zoned labradorite-oligoclase with very rare albitic rims. Reverse or oscillatory zoning is less common. Typically, plagioclase crystals from MMEs display blue or blue-violet bright cathodoluminescence (Fig. 4b-e). Calcic cores are strongly altered to a mixture of secondary Ca-bearing minerals. Sometimes, secondary calcite fills the microfractures and interstices adjacent to plagioclase. Some crystals (up to $2 \mathrm{~cm}$ ) that occur close to the enclave/granite contacts have margins with olive-green to dull ochre CL, similar to the luminescence that is typical for the plagioclase in the granite (Fig. 4b-d). Therefore, these crystals are interpreted as xenocrysts that were mechanically introduced into the MMEs from the granitic host (Vernon et al. 1988; Vernon 2010). The plagioclase grains display oscillatory zoning with patchily zoned cores (Fig. 4d). Another plagioclase grain has a strongly altered core (Fig. 4b, c).

$\mathrm{K}$-feldspar appears only in MMEs that contain higher than average amounts of quartz and lower contents of biotite. It represents interstitial, rarely poikilitic perthitic microcline with homogeneous blue CL. K-feldspar most likely crystallized from the late-stage hydrous granitic melts or orthomagmatic fluids that percolated from the surrounding granite. Some MMEs contain phenocrysts of K-feldspar. These phenocrysts are commonly mantled by a thin band of biotite and are identical in size, texture, luminescence properties (oscillatory zoning) and composition to those in the surrounding granite (Fig. 4e). Therefore, they are also regarded as xenocrysts (Vernon et al. 1988; Vernon 2010).

Both the plagioclase and $\mathrm{K}$-feldspar xenocrysts that appear inside MMEs have sub-rounded to rounded morphologies resulting from the partial fusion of the crystal rim in higher temperature mafic magma globules (Fig. 4b, d, e).

The biotite grains in MMEs are similar to the biotite grains in the surrounding granite. In most cases, biotite forms subhedral ragged platy crystals that are up to $0.7 \mathrm{~mm}$ long and very uniform in size. In smaller MMEs and in the chilled margins of larger enclaves, biotite is lath-shaped. Crystals with sizes similar to those of the biotite in the 
granitic host $(5-6 \mathrm{~mm})$ are uncommon. In contrast to the biotite from the HBG, the biotite in MMEs is poor in mineral inclusions.

Minor amphibole is usually euhedral and occurs as short prismatic crystals that are $0.5-1 \mathrm{~mm}$ long and often intergrown with primary biotite. Scarce skeletal amphibole crystals occur as inclusions in quartz (Fig. 3c). Biotitization and/ or chloritization are common alterations.

Compared to the HBG, MMEs are relatively poor in allanite and abundant in acicular apatite (Figs. 3f, 4f). The acicular morphology of apatite is also an indication of magma mixing-mingling processes. The rapid growth of apatite in a quenched mixing system results in acicular crystal shapes, rather than stubby prismatic apatite (Wyllie et al. 1962; Hibbard 1991). Prismatic, zoned apatites are rare and occur only as inclusions in the rims of feldspar xenocrysts (Fig. 4f). This type of apatite may represent the product of an earlier crystallization episode (within the granitoid magma).

Zircon occurs as short prismatic grains typically as inclusions in biotite and amphibole, although more rarely it is also present in feldspars. The chloritization of biotite and amphibole is associated with the appearance of secondary epidote, titanite and ilmenite.

The above-described textures and microtextures may indicate that the MMEs from the HBG represent globules of more mafic magma (or hybrid magma) that comingled with a more felsic host melt.

\section{Mineral compositions}

\section{Feldspars}

The compositions of plagioclase are given in Table 2 (supplementary material) and Fig. 5. The plagioclase grains from the HBG display a wide range of compositions from andesine $\left(\max \mathrm{An}_{46}\right)$ to albite, and their Or contents reach up to 5.3\%. In MMEs, the groundmass plagioclase cores are more calcic, with An contents of 45.3-65.7\%, and albitic compositions are rare and less common than in the HBG. The Or content reaches up to $8.1 \%$ (Fig. 5).

The K-feldspar phenocrysts from the HBG and associated MMEs show similar compositions (Table 3, supplementary material). In the cryptoperthitic domains, the Ab content ranges from 23.8 to $33.3 \%$, while in the remaining regions of the crystals, where the primary distribution of $\mathrm{Na}$ and $\mathrm{K}$ has been reset by subsolidus alteration to various extents, the $\mathrm{Ab}$ content varies between 1.7 and $17.6 \%$ (Fig. 6). The compositional gap in the $\mathrm{Ab}$ content between ca. 18 and $24 \%$ may reflect the difference in temperature regime during the processes of crystallization and subsolidus alteration of alkali feldspar. Groundmass K-feldspar grains from the HBG and MMEs display very restricted $\mathrm{Ab}$ contents of 2-5.5\%; these values correspond to the compositions of the most Na-poor domains in the phenocrysts. The concentration of $\mathrm{Ba}$ in the groundmass $\mathrm{K}$-feldspar reaches up to $0.62 \mathrm{wt} . \% \mathrm{BaO}$ and is generally lower than that in the phenocrysts $(0-1.86 \mathrm{wt} . \%)$.

\section{Biotite}

Generally, the composition of HBG biotite is Fe-biotite according to the nomenclature of Foster (1960); this biotite exhibits low and rather restricted $\mathrm{Mg} /\left(\mathrm{Mg}+\mathrm{Fe}_{\text {tot }}\right)$ ratios of $0.16-0.26$ and thus corresponds to annite (Table 4, supplementary material).

The compositions of the biotite from MMEs are consistent with the compositions of the biotite from the HBG, which suggests their advanced chemical equilibration (Table 4, supplementary material) (Fig. 7).

\section{Amphibole}

Amphibole is a rare phase in both granite and enclaves. Based on the classification of Hawthorne et al. (2012), the amphibole from the HBG and associated MMEs is hastingsite (Fig. 8) with $0.91 \leq \mathrm{Ca} /(\mathrm{Ca}+\mathrm{Na}) \leq 0.94$. The hastingsite from the $\mathrm{HBG}$ records $24.84-28.88 \mathrm{wt}$. $\% \mathrm{FeO}_{\text {tot }}, 7.77-9.15$ wt. $\% \mathrm{Al}_{2} \mathrm{O}_{3}$ and 3.76-5.91 wt. $\% \mathrm{MgO}$. The $\mathrm{Mg} /\left(\mathrm{Mg}+\mathrm{Fe}^{2+}\right)$ values range from 0.23 to 0.36 , and the calculated $\mathrm{Fe}^{3+} / \mathrm{Fe}^{2+}$ values are $0.20-0.38$ (Fig. 8; Table 5, supplementary material). The contents of $\mathrm{TiO}_{2}$ and $\mathrm{MnO}$ do not exceed 2.26 and $1.20 \mathrm{wt} . \%$, respectively.

The hastingsite from the MMEs has 26.94-29.32 wt. $\% \mathrm{FeO}_{\text {tot }}$ and $7.38-8.56$ wt. $\% \mathrm{Al}_{2} \mathrm{O}_{3}$, values similar to those observed in the amphibole from the HBG. However, the hastingsite from MMEs is slightly poorer in $\mathrm{Mg}$ $\left[\mathrm{MgO}=3.14-4.33\right.$ wt. $\left.\% ; \mathrm{Mg} /\left(\mathrm{Mg}+\mathrm{Fe}^{2+}\right)=0.19-0.25\right]$ and records a lower degree of iron oxidation, with the calculated $\mathrm{Fe}^{3+} / \mathrm{Fe}^{2+}$ values ranging from 0.15 to 0.23 . The contents of $\mathrm{TiO}_{2}$ and $\mathrm{MnO}$ are up to 2.07 and $1.17 \mathrm{wt} . \%$, respectively.

\section{Accessory minerals}

The main accessory minerals in the HBG are apatite, allanite and zircon. Apatite has a nearly stoichiometric composition, with $\mathrm{MnO}$ contents ranging from below the detection limit to 1.06 wt.\% (Table 6 , supplementary material). The REE contents are below the detection limit of EPMA. Allanite is usually metamict and strongly altered. Relatively unaltered crystals display analytical totals between 99.49 and 100.34 wt.\% and Si cation contents close to 3 apfu. These compositions correspond to allanite-(Ce), with cerium considerably dominant relative to the other REEs $(\mathrm{Ce} / \mathrm{REE}=0.57-0.58)$ (Table 7, supplementary material). Allanite has low concentrations of $\mathrm{MnO}$ and $\mathrm{TiO}_{2}$ ( $\leq 0.11$ and 1.79-2.44 wt.\%, respectively) and highly variable calculated $\mathrm{Fe}^{3+} / \mathrm{Fe}^{2+}$ ratios ranging from 0.85 to 1.73 . Zircon shows oscillatory zoning, 
Table 2 Major and trace element analyses of MMEs

\begin{tabular}{|c|c|c|c|c|c|c|c|c|c|c|c|c|}
\hline Sample & 016 & 025 & 026 & 031 & 040 & 042 & 046 & 047 & 048 & 049 & 050 & 056 \\
\hline Locality & 1 & 1 & 1 & 2 & 3 & 3 & 4 & 4 & 4 & 4 & 4 & 5 \\
\hline \multicolumn{13}{|l|}{ wt.\% } \\
\hline $\mathrm{SiO}_{2}$ & 60.32 & 61.28 & 53.30 & 66.26 & 63.46 & 60.44 & 53.09 & 62.54 & 63.99 & 62.98 & 57.81 & 52.75 \\
\hline $\mathrm{TiO}_{2}$ & 1.15 & 0.79 & 1.10 & 0.78 & 0.87 & 1.12 & 1.52 & 0.83 & 0.75 & 0.77 & 1.14 & 1.36 \\
\hline $\mathrm{Al}_{2} \mathrm{O}_{3}$ & 15.21 & 15.33 & 16.23 & 15.05 & 16.61 & 15.01 & 16.39 & 15.31 & 14.71 & 14.75 & 15.78 & 17.37 \\
\hline $\mathrm{Fe}_{2} \mathrm{O}_{3} t$ & 9.24 & 9.14 & 13.71 & 6.10 & 5.78 & 10.28 & 15.74 & 8.09 & 8.17 & 8.70 & 11.25 & 13.55 \\
\hline $\mathrm{MnO}$ & 0.22 & 0.16 & 0.31 & 0.12 & 0.12 & 0.18 & 0.17 & 0.16 & 0.18 & 0.21 & 0.23 & 0.27 \\
\hline $\mathrm{MgO}$ & 1.06 & 0.90 & 1.67 & 0.98 & 1.42 & 1.27 & 1.63 & 0.90 & 1.16 & 1.16 & 1.19 & 2.02 \\
\hline $\mathrm{CaO}$ & 3.01 & 2.17 & 3.58 & 2.89 & 3.74 & 3.17 & 2.44 & 2.60 & 2.85 & 2.34 & 2.77 & 3.26 \\
\hline $\mathrm{Na}_{2} \mathrm{O}$ & 4.90 & 5.32 & 4.84 & 4.40 & 4.19 & 4.18 & 4.87 & 4.92 & 3.96 & 4.22 & 5.26 & 3.92 \\
\hline $\mathrm{K}_{2} \mathrm{O}$ & 1.53 & 2.19 & 2.85 & 2.18 & 2.43 & 2.66 & 0.99 & 2.14 & 2.81 & 2.41 & 2.31 & 4.10 \\
\hline $\mathrm{P}_{2} \mathrm{O}_{5}$ & 0.41 & 0.27 & 0.38 & 0.26 & 0.28 & 0.44 & 0.65 & 0.26 & 0.24 & 0.23 & 0.36 & 0.49 \\
\hline LOI & 1.70 & 1.34 & 1.30 & 0.66 & 0.43 & 0.42 & 2.44 & 1.36 & 0.82 & 1.34 & 1.52 & 0.67 \\
\hline Total & 98.90 & 99.05 & 99.46 & 99.82 & 99.47 & 99.34 & 99.93 & 99.28 & 99.78 & 99.27 & 99.81 & 100.00 \\
\hline $\mathrm{A} / \mathrm{CNK}$ & 1.00 & 1.02 & 0.92 & 1.01 & 1.02 & 0.97 & 1.21 & 1.01 & 1.00 & 1.07 & 0.97 & 1.03 \\
\hline Mg no. & 0.19 & 0.16 & 0.19 & 0.24 & 0.33 & 0.20 & 0.17 & 0.18 & 0.22 & 0.21 & 0.17 & 0.23 \\
\hline \multicolumn{13}{|l|}{ ppm } \\
\hline $\mathrm{Ba}$ & 440.0 & 167.9 & 361.0 & 371.7 & 278.4 & 370.9 & 185.8 & 314.5 & 457.0 & 425.5 & 215.1 & 382.0 \\
\hline Cs & 13.6 & 14.3 & 13.7 & 7.8 & 11.2 & 8.8 & 1.2 & 8.2 & 7.0 & 5.3 & 14.7 & 37.3 \\
\hline $\mathrm{Rb}$ & 172.4 & 254.3 & 310.1 & 184.4 & 217.7 & 264.9 & 84.7 & 252.8 & 212.6 & 182.4 & 251.7 & 545.9 \\
\hline $\mathrm{Sr}$ & 95.1 & 58.0 & 83.6 & 112.2 & 201.1 & 103.6 & 82.7 & 84.5 & 118.6 & 121.4 & 74.3 & 73.2 \\
\hline V & 80.0 & 43.0 & 77.0 & 62.0 & 76.0 & 92.0 & 83.0 & 55.0 & 66.0 & 63.0 & 75.0 & 101.0 \\
\hline $\mathrm{Co}$ & 8.4 & 6.7 & 8.9 & 7.6 & 9.9 & 11.7 & 12.0 & 8.2 & 8.0 & 8.2 & 9.3 & 16.2 \\
\hline $\mathrm{Zr}$ & 260.0 & 481.2 & 340.9 & 349.3 & 380.1 & 343.5 & 560.9 & 436.3 & 273.8 & 289.5 & 466.4 & 374.0 \\
\hline Hf & 9.5 & 14.9 & 10.6 & 8.6 & 9.6 & 8.8 & 18.2 & 13.7 & 8.7 & 9.7 & 14.0 & 9.8 \\
\hline $\mathrm{Y}$ & 125.7 & 98.3 & 89.5 & 52.5 & 41.6 & 69.8 & 132.3 & 92.4 & 73.2 & 95.2 & 122.4 & 86.3 \\
\hline $\mathrm{Nb}$ & 90.2 & 90.3 & 89.8 & 33.9 & 33.9 & 67.0 & 151.6 & 74.3 & 45.7 & 53.5 & 91.9 & 75.3 \\
\hline $\mathrm{Ta}$ & 6.9 & 9.5 & 9.2 & 2.3 & 2.1 & 3.0 & 13.4 & 7.3 & 4.0 & 5.1 & 6.8 & 5.4 \\
\hline $\mathrm{U}$ & 39.4 & 22.0 & 21.5 & 17.9 & 3.3 & 3.4 & 29.1 & 20.3 & 7.2 & 8.8 & 29.0 & 7.9 \\
\hline Th & 12.1 & 23.4 & 17.0 & 14.6 & 15.4 & 9.7 & 45.2 & 21.2 & 11.6 & 12.1 & 15.8 & 17.2 \\
\hline $\mathrm{La}$ & 27.4 & 18.1 & 23.1 & 55.1 & 64.4 & 44.1 & 28.5 & 55.9 & 35.8 & 34.0 & 26.5 & 30.5 \\
\hline $\mathrm{Ce}$ & 71.0 & 36.6 & 54.4 & 101.8 & 114.7 & 95.7 & 57.5 & 112.1 & 80.4 & 74.9 & 62.9 & 67.1 \\
\hline $\operatorname{Pr}$ & 10.8 & 5.2 & 7.6 & 11.6 & 13.5 & 11.4 & 7.8 & 12.2 & 10.6 & 9.9 & 9.0 & 9.0 \\
\hline $\mathrm{Nd}$ & 50.8 & 24.6 & 33.5 & 45.2 & 49.8 & 50.1 & 34.5 & 50.1 & 47.1 & 44.1 & 43.3 & 41.2 \\
\hline $\mathrm{Sm}$ & 15.5 & 8.8 & 10.7 & 9.2 & 9.0 & 11.5 & 12.1 & 11.4 & 11.7 & 11.6 & 13.7 & 11.2 \\
\hline $\mathrm{Eu}$ & 1.1 & 0.7 & 0.8 & 1.0 & 1.5 & 1.0 & 0.7 & 0.9 & 1.1 & 1.2 & 0.8 & 0.8 \\
\hline $\mathrm{Gd}$ & 18.8 & 11.5 & 12.8 & 8.9 & 7.5 & 12.1 & 16.5 & 11.5 & 12.5 & 13.4 & 16.9 & 12.7 \\
\hline $\mathrm{Tb}$ & 3.4 & 2.3 & 2.2 & 1.5 & 1.3 & 2.1 & 3.0 & 2.2 & 2.2 & 2.5 & 3.0 & 2.4 \\
\hline Dy & 21.9 & 13.8 & 14.1 & 8.6 & 6.5 & 11.2 & 19.0 & 13.1 & 13.7 & 15.0 & 19.0 & 14.5 \\
\hline Ho & 4.7 & 2.8 & 3.1 & 1.7 & 1.3 & 2.3 & 3.7 & 2.8 & 2.6 & 3.0 & 3.6 & 2.5 \\
\hline $\mathrm{Er}$ & 14.8 & 8.3 & 9.2 & 4.6 & 3.8 & 6.0 & 11.7 & 8.4 & 8.1 & 8.7 & 10.9 & 7.0 \\
\hline $\mathrm{Tm}$ & 2.1 & 1.3 & 1.4 & 0.7 & 0.5 & 0.8 & 1.7 & 1.3 & 1.2 & 1.3 & 1.7 & 1.1 \\
\hline $\mathrm{Yb}$ & 14.8 & 9.5 & 9.1 & 4.8 & 3.5 & 5.5 & 13.7 & 9.0 & 7.9 & 9.7 & 12.2 & 7.0 \\
\hline $\mathrm{Lu}$ & 2.2 & 1.3 & 1.3 & 0.7 & 0.5 & 0.7 & 1.8 & 1.3 & 1.1 & 1.4 & 1.7 & 0.9 \\
\hline$(\mathrm{La} / \mathrm{Yb})_{\mathrm{N}}$ & 1.2 & 1.3 & 1.7 & 7.7 & 12.2 & 5.4 & 1.4 & 4.1 & 3.0 & 2.4 & 1.4 & 2.9 \\
\hline $\mathrm{Eu} / \mathrm{Eu}^{*}$ & 0.2 & 0.2 & 0.2 & 0.3 & 0.6 & 0.3 & 0.2 & 0.2 & 0.3 & 0.3 & 0.2 & 0.2 \\
\hline
\end{tabular}


Table 2 (continued)

\begin{tabular}{|c|c|c|c|c|c|c|c|c|c|c|c|c|c|}
\hline Sample & 061 & 083 & 092 & 093 & 097 & 100 & 103 & 104 & 105 & 108 & 117 & 144 & 145 \\
\hline Locality & 6 & 8 & 9 & 9 & 10 & 10 & 4 & 4 & 4 & 4 & 3 & 4 & 4 \\
\hline \multicolumn{14}{|l|}{ wt. $\%$} \\
\hline $\mathrm{SiO}_{2}$ & 58.64 & 55.46 & 50.62 & 61.92 & 57.40 & 64.78 & 68.95 & 51.63 & 59.77 & 64.58 & 63.30 & 69.23 & 55.08 \\
\hline $\mathrm{TiO}_{2}$ & 1.16 & 1.23 & 1.44 & 0.87 & 1.01 & 0.79 & 0.47 & 1.30 & 0.94 & 0.79 & 0.92 & 0.41 & 0.97 \\
\hline $\mathrm{Al}_{2} \mathrm{O}_{3}$ & 15.19 & 15.99 & 16.38 & 15.68 & 16.91 & 14.60 & 14.84 & 15.24 & 15.42 & 14.61 & 14.97 & 14.42 & 17.19 \\
\hline $\mathrm{Fe}_{2} \mathrm{O}_{3} t$ & 11.90 & 12.79 & 16.33 & 8.18 & 9.12 & 7.00 & 4.28 & 17.47 & 9.33 & 7.44 & 7.98 & 3.78 & 10.33 \\
\hline $\mathrm{MnO}$ & 0.22 & 0.29 & 0.47 & 0.22 & 0.21 & 0.15 & 0.08 & 0.42 & 0.18 & 0.13 & 0.14 & 0.06 & 0.19 \\
\hline $\mathrm{MgO}$ & 1.27 & 1.31 & 1.55 & 0.86 & 1.22 & 0.90 & 0.52 & 2.29 & 1.13 & 1.02 & 1.18 & 0.46 & 1.27 \\
\hline $\mathrm{CaO}$ & 2.94 & 2.74 & 2.57 & 2.96 & 3.65 & 2.91 & 2.15 & 4.42 & 2.45 & 2.97 & 1.98 & 2.04 & 2.55 \\
\hline $\mathrm{Na}_{2} \mathrm{O}$ & 4.13 & 4.53 & 4.28 & 4.33 & 5.40 & 4.12 & 4.00 & 3.89 & 4.74 & 4.36 & 4.36 & 4.07 & 5.91 \\
\hline $\mathrm{K}_{2} \mathrm{O}$ & 3.21 & 2.94 & 3.40 & 2.63 & 2.16 & 3.02 & 3.84 & 3.30 & 2.93 & 2.16 & 1.41 & 3.25 & 2.06 \\
\hline $\mathrm{P}_{2} \mathrm{O}_{5}$ & 0.47 & 0.44 & 0.62 & 0.27 & 0.41 & 0.22 & 0.11 & 0.39 & 0.37 & 0.29 & 0.31 & 0.09 & 0.48 \\
\hline LOI & 0.57 & 1.67 & 1.86 & 0.88 & 1.86 & 0.40 & 0.44 & 0.58 & 1.41 & 0.55 & 2.34 & 1.70 & 3.60 \\
\hline Total & 99.90 & 99.61 & 99.75 & 98.96 & 99.50 & 99.05 & 99.83 & 99.90 & 98.88 & 99.06 & 99.02 & 99.51 & 99.63 \\
\hline A/CNK & 0.97 & 1.02 & 1.06 & 1.02 & 0.95 & 0.95 & 1.01 & 0.85 & 1.00 & 0.98 & 1.22 & 1.04 & 1.04 \\
\hline Mg no. & 0.17 & 0.17 & 0.16 & 0.17 & 0.21 & 0.20 & 0.19 & 0.21 & 0.19 & 0.21 & 0.23 & 0.19 & 0.20 \\
\hline \multicolumn{14}{|l|}{ ppm } \\
\hline $\mathrm{Ba}$ & 449.7 & 289.7 & 409.9 & 335.0 & 177.5 & 383.8 & 587.8 & 368.7 & 354.0 & 279.0 & 351.5 & 356.2 & 361.9 \\
\hline Cs & 18.9 & 12.0 & 34.0 & 18.9 & 11.8 & 8.2 & 5.8 & 32.2 & 10.0 & 6.1 & 1.6 & 6.1 & 14.9 \\
\hline $\mathrm{Rb}$ & 367.7 & 354.6 & 488.5 & 260.8 & 222.2 & 207.8 & 237.1 & 451.5 & 334.9 & 168.6 & 88.2 & 187.8 & 239.1 \\
\hline $\mathrm{Sr}$ & 89.4 & 70.2 & 74.5 & 121.4 & 114.3 & 121.6 & 93.5 & 68.7 & 101.4 & 115.5 & 124.0 & 95.1 & 89.4 \\
\hline V & 55.0 & 68.0 & 63.0 & 52.0 & 66.0 & 54.0 & 22.0 & 112.0 & 49.0 & 59.0 & 74.0 & 19.0 & 62.0 \\
\hline $\mathrm{Co}$ & 9.0 & 10.3 & 12.2 & 7.1 & 9.8 & 8.5 & 4.5 & 15.3 & 8.9 & 7.1 & 9.0 & 3.7 & 8.7 \\
\hline $\mathrm{Zr}$ & 372.9 & 522.1 & 437.1 & 311.3 & 319.8 & 395.0 & 387.1 & 309.7 & 512.7 & 350.9 & 398.3 & 323.0 & 535.4 \\
\hline Hf & 9.9 & 18.3 & 13.9 & 9.9 & 10.3 & 10.1 & 11.0 & 10.4 & 15.6 & 9.4 & 10.6 & 9.4 & 16.3 \\
\hline $\mathrm{Y}$ & 77.2 & 105.0 & 102.9 & 59.2 & 149.6 & 67.6 & 46.4 & 198.0 & 110.1 & 50.4 & 74.2 & 45.6 & 97.4 \\
\hline $\mathrm{Nb}$ & 72.7 & 111.3 & 114.8 & 65.3 & 81.2 & 49.6 & 30.8 & 92.7 & 86.2 & 39.9 & 55.4 & 27.5 & 77.7 \\
\hline $\mathrm{Ta}$ & 7.9 & 13.6 & 12.4 & 4.7 & 6.6 & 2.8 & 1.9 & 8.4 & 7.8 & 2.3 & 5.5 & 2.5 & 7.0 \\
\hline $\mathrm{U}$ & 5.5 & 16.5 & 25.6 & 12.5 & 13.1 & 5.6 & 5.6 & 7.2 & 47.0 & 7.4 & 4.6 & 13.3 & 21.9 \\
\hline Th & 11.6 & 20.5 & 18.9 & 11.8 & 14.9 & 16.2 & 20.4 & 10.1 & 19.1 & 10.0 & 17.9 & 18.3 & 21.2 \\
\hline $\mathrm{La}$ & 42.5 & 41.0 & 39.3 & 38.1 & 29.8 & 64.2 & 63.6 & 34.7 & 23.0 & 28.5 & 39.7 & 56.1 & 20.0 \\
\hline $\mathrm{Ce}$ & 100.5 & 89.2 & 78.7 & 91.5 & 73.3 & 127.7 & 121.6 & 100.4 & 49.5 & 64.7 & 73.9 & 106.4 & 45.8 \\
\hline $\operatorname{Pr}$ & 12.2 & 11.3 & 9.8 & 11.4 & 10.5 & 14.4 & 12.8 & 16.2 & 6.8 & 8.3 & 9.3 & 12.0 & 6.4 \\
\hline $\mathrm{Nd}$ & 49.7 & 47.7 & 41.3 & 45.6 & 53.4 & 56.4 & 45.3 & 82.6 & 33.1 & 40.4 & 40.2 & 46.1 & 32.1 \\
\hline $\mathrm{Sm}$ & 11.2 & 11.9 & 10.6 & 12.1 & 16.8 & 12.8 & 8.0 & 23.4 & 9.7 & 9.3 & 9.8 & 8.6 & 10.4 \\
\hline $\mathrm{Eu}$ & 0.8 & 0.7 & 0.5 & 1.2 & 1.6 & 1.3 & 0.9 & 1.2 & 0.8 & 1.1 & 0.6 & 1.0 & 0.9 \\
\hline Gd & 11.0 & 14.1 & 13.1 & 11.7 & 20.2 & 12.2 & 7.5 & 28.1 & 13.4 & 10.0 & 11.5 & 6.9 & 13.1 \\
\hline $\mathrm{Tb}$ & 2.0 & 2.5 & 2.3 & 1.9 & 3.9 & 2.1 & 1.3 & 5.3 & 2.5 & 1.5 & 2.1 & 1.3 & 2.6 \\
\hline Dy & 11.9 & 15.5 & 15.0 & 10.8 & 23.8 & 10.7 & 7.6 & 32.8 & 15.0 & 8.8 & 12.9 & 7.1 & 15.3 \\
\hline Ho & 2.1 & 2.8 & 2.8 & 2.3 & 5.0 & 2.2 & 1.3 & 5.9 & 3.1 & 1.8 & 2.3 & 1.5 & 3.2 \\
\hline $\mathrm{Er}$ & 6.1 & 8.2 & 7.9 & 6.6 & 13.9 & 5.9 & 3.8 & 16.6 & 9.4 & 5.5 & 6.2 & 4.2 & 9.2 \\
\hline $\mathrm{Tm}$ & 0.9 & 1.3 & 1.2 & 0.9 & 2.0 & 0.9 & 0.6 & 2.6 & 1.6 & 0.8 & 0.9 & 0.7 & 1.5 \\
\hline $\mathrm{Yb}$ & 6.2 & 9.3 & 8.2 & 6.0 & 14.0 & 5.8 & 4.0 & 17.2 & 10.5 & 4.8 & 6.1 & 4.4 & 9.6 \\
\hline $\mathrm{Lu}$ & 0.9 & 1.4 & 1.2 & 0.9 & 1.8 & 0.8 & 0.6 & 2.4 & 1.6 & 0.7 & 0.8 & 0.6 & 1.4 \\
\hline$(\mathrm{La} / \mathrm{Yb})_{\mathrm{N}}$ & 4.6 & 2.9 & 3.2 & 4.2 & 1.4 & 7.5 & 10.6 & 1.3 & 1.5 & 4.0 & 4.4 & 8.5 & 1.4 \\
\hline $\mathrm{Eu} / \mathrm{Eu}^{*}$ & 0.2 & 0.2 & 0.1 & 0.3 & 0.3 & 0.3 & 0.4 & 0.1 & 0.2 & 0.4 & 0.2 & 0.4 & 0.2 \\
\hline
\end{tabular}

LOI loss on ignition, $A / C N K \mathrm{Al}_{2} \mathrm{O}_{3} /\left(\mathrm{CaO}+\mathrm{NaO}+\mathrm{K}_{2} \mathrm{O}\right)$ molar; $M g$ no. atomic $\mathrm{Mg} /(\mathrm{Mg}+\mathrm{Fe}), E u / E u^{*}\left[\mathrm{Eu}_{\mathrm{N}} / \sqrt{ }\left(\mathrm{Sm}_{\mathrm{N}} \times \mathrm{Gd}_{\mathrm{N}}\right)\right], N$ chondrite normalized to values of Nakamura (1974)

Locality: 1-Strzegom, 2-Goczałków, 3-Wieśnica, 4-Kostrza, 5-Gniewków, 6-Czernica, 7-Zimnik, 8-Rogoźnica, 9-Paszowice, 10-Borów 


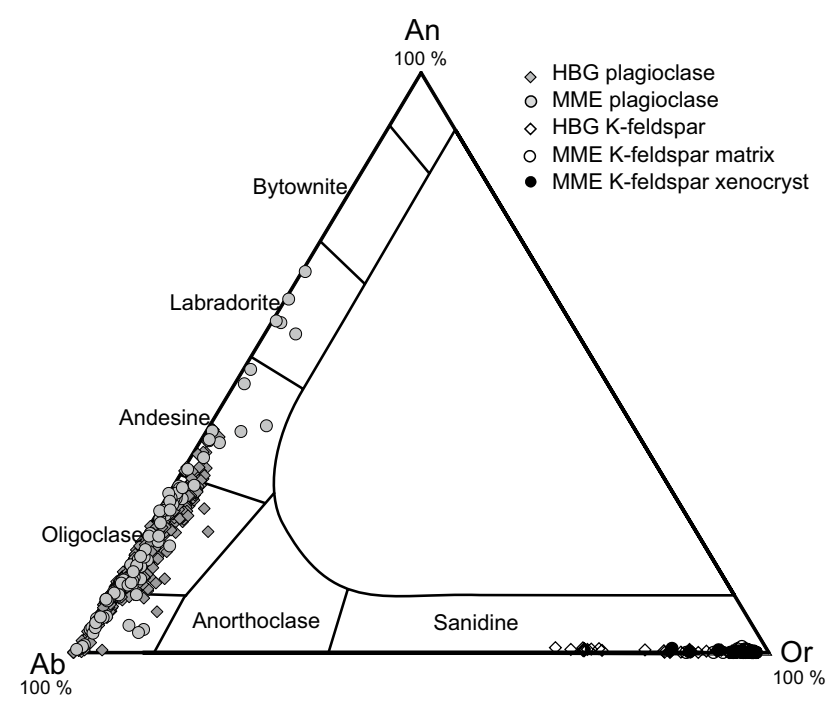

Fig. 5 Feldspars chemistry of HBG and MMEs. Plot of the EMPA data in the feldspar classification diagram

reflecting heterogeneous distribution of trace elements during magmatic growth (as revealed by CL and SEM analyses). This zoning pattern is most likely related to differences in the contents of elements below the detection levels of EPMA, as it shows no correlation to variations in the elements detected. The $\mathrm{Zr} / \mathrm{Hf}$ ratios in the zircon vary between 80.28 and 118.09 (Table 8, supplementary material). Detailed chemical characteristics of zircon are presented by Turniak et al. (2014).

\section{Whole-rock geochemistry}

The HBG is weakly peraluminous, with molecular A/CNK ratios ranging from 0.99 to 1.06 (Fig. 9a; Table 1). The $\mathrm{Mg}$ number is low; the atomic $\mathrm{Mg} /(\mathrm{Mg}+\mathrm{Fe})$ values range from 0.15 to 0.30 (Table 1). On the $\left(\mathrm{Na}_{2} \mathrm{O}+\mathrm{K}_{2} \mathrm{O}\right)$ vs $\mathrm{SiO}_{2}$ diagram (Fig. 9c), the HBG samples plot in the upper part of the sub-alkaline field. The rock is $\mathrm{K}_{2} \mathrm{O}$-rich (4.04-5.37 wt.\%) with a low $\mathrm{Na}_{2} \mathrm{O} / \mathrm{K}_{2} \mathrm{O}$ ratio (less than 1) and plots in the high-K field on the $\mathrm{K}_{2} \mathrm{O}$ vs $\mathrm{SiO}_{2}$ diagram (Fig. 9b). The HBG mainly exhibits calc-alkalic characteristics (Fig. 9d).

MMEs are characterized by a broad compositional range, with $\mathrm{SiO}_{2}$ contents varying from 51 to $71 \mathrm{wt} \%$ (Table 2). The Mg numbers are low and similar to those of the host granite $(0.16-0.33)$. The $\mathrm{Na}_{2} \mathrm{O} / \mathrm{K}_{2} \mathrm{O}$ ratios range between 0.96 and 4.92 with an average value of 1.92 . Enclaves are peraluminous and metaluminous, with A/CNK ratios between 0.85 and 1.22 (Fig. 9a).

On the Harker diagrams, no visible chemical gap between the MMEs and the HBG is evident (Fig. 10). Both rock types show well-defined trends for most of their major and trace elements. However, while most of the major elements (e.g., Ti, Al, Fe, Mg and $\mathrm{Ca}$ ) exhibit a common line of melt evolution over a wide range of silica compositions in the range of approximately 51-75 wt.\% (selected diagram shown in Fig. 10), the trends for elements such as $\mathrm{Na}, \mathrm{K}, \mathrm{Ba}, \mathrm{Rb}, \mathrm{Zr}$, and $\mathrm{La}$ are different for the $\mathrm{HBG}$ and MMEs, with a marked bending at approximately $64 \mathrm{wt} \%$ $\mathrm{SiO}_{2}$. Compared to the HBG samples, MMEs are depleted in $\mathrm{Si}, \mathrm{K}, \mathrm{Ba}$, and $\mathrm{La}$ and enriched in $\mathrm{Ti}, \mathrm{Fe}, \mathrm{Mg}, \mathrm{Ca}, \mathrm{Nb}$, $\mathrm{Zr}, \mathrm{V}, \mathrm{Y}$ and $\mathrm{Yb}$.

The chondrite-normalized (Nakamura 1974) rare-earth element patterns for the HBG and MMEs are shown in Fig. 11. The REE patterns for the HBG are homogeneous, showing moderately steep patterns for LREEs and nearly flat patterns for HREEs, with $(\mathrm{La} / \mathrm{Yb})_{\mathrm{N}}=6.4-19.3$ (Table 1). Thus, the granite is enriched in LREEs (58-170 times more than chondrite) with respect to HREEs (11-22 times more than chondrite). As a result, the described rocks exhibit a well-defined fractionation of LREEs with $(\mathrm{La} / \mathrm{Sm})_{\mathrm{N}}=3.4-5.6$ and a weak fractionation of HREEs with $(\mathrm{Gd} / \mathrm{Yb})_{\mathrm{N}}=1.1-2.5$. All the samples display significant negative $\mathrm{Eu}$ anomalies, i.e., $\mathrm{Eu} / \mathrm{Eu}^{*}=0.3-0.6$.

The characteristic features of MMEs are gentle slopes of the patterns for LREEs and nearly flat slopes for HREEs with $(\mathrm{La} / \mathrm{Yb})_{\mathrm{N}}=1.2-12.2$ (Table 2 ). MMEs are slightly more fractionated in LREEs relative to HREEs with (La/ $\mathrm{Sm})_{\mathrm{N}}=0.9-4.9$ and $(\mathrm{Gd} / \mathrm{Yb})_{\mathrm{N}}=1.0-1.8$. All enclaves show negative $\mathrm{Eu}$ anomalies, with $\mathrm{Eu} / \mathrm{Eu}^{*}=0.1-0.6$. Compared to the HBG, MMEs are characterized by lower concentrations of LREEs and higher concentrations of HREEs. The enrichment of HREEs in MMEs can be explained by the preferential partitioning of REEs between mafic and felsic melts (Watson 1976; Ryerson and Hess 1978).

The trace element signatures of the HBG and MMEs are presented on primitive mantle-normalized (Sun and McDonough 1989) multi-element diagrams (Fig. 12). Both the HBG and MMEs are enriched in large-ion lithophile elements (LILEs) and depleted in high field strength elements (HFSEs) compared to the primitive mantle. The HBG shows relatively homogeneous patterns with negative anomalies for $\mathrm{Ba}, \mathrm{Nb}, \mathrm{Sr}, \mathrm{P}, \mathrm{Eu}$ and $\mathrm{Ti}$. These negative anomalies may reflect the fractionation of plagioclase, apatite, and Fe-Ti oxides during the earlier stages of magma evolution.

The trace element patterns of MMEs are much more complex than those of the HBG (Fig. 12). Most of the enclaves exhibit negative anomalies for $\mathrm{Ba}, \mathrm{K}, \mathrm{Nb}, \mathrm{La}$, $\mathrm{Sr}$ and $\mathrm{P}$, although some samples show no $\mathrm{Nb}, \mathrm{La}$ or $\mathrm{P}$ anomalies. 


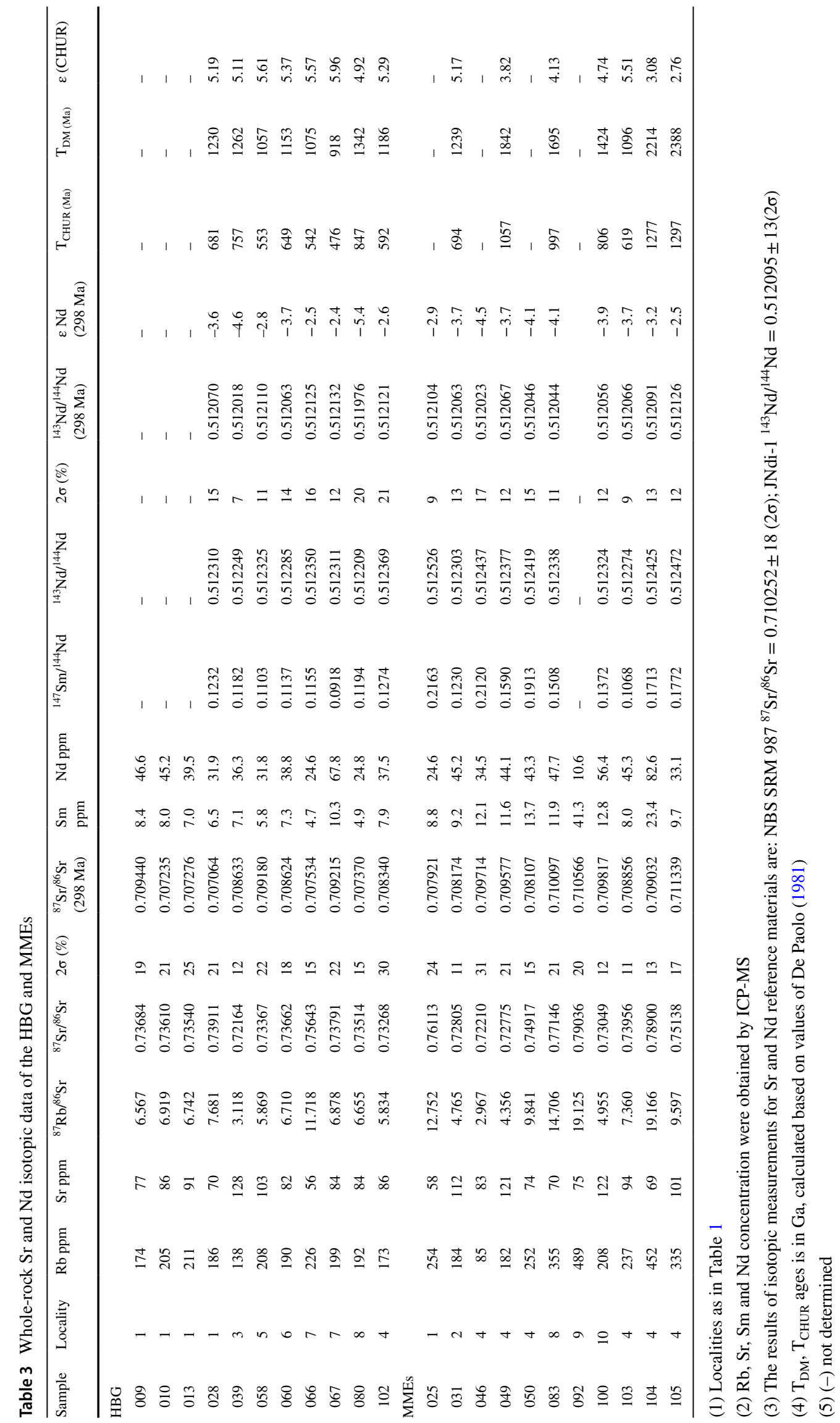




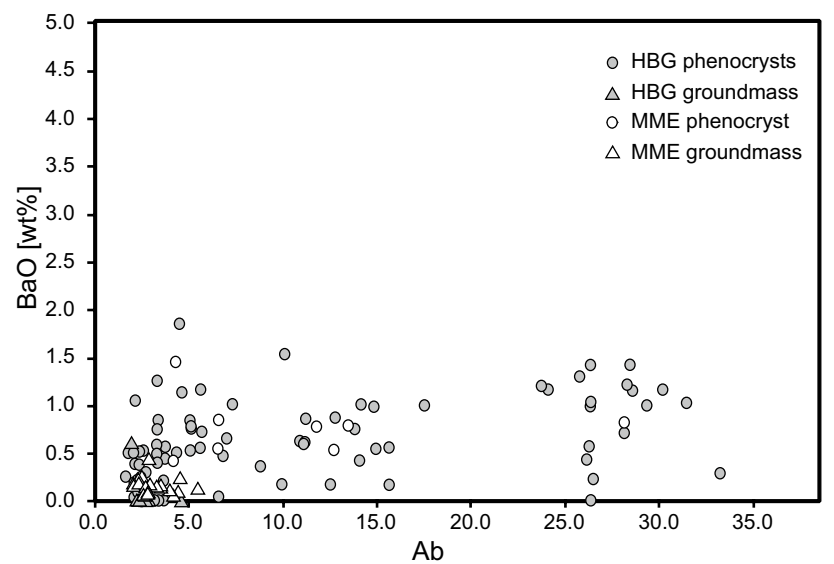

Fig. 6 Feldspars chemistry of HBG and MMEs. Ab vs BaO diagram shows the enrichment of $\mathrm{BaO}$ in $\mathrm{K}$-feldspars

\section{Sr-Nd isotope data}

The $\mathrm{Sr}-\mathrm{Nd}$ isotope compositions of the HBG and MMEs are given in Table 3 and plotted in Fig. 13. The SHRIMP $\mathrm{U}-\mathrm{Pb}$ zircon age of $298 \mathrm{Ma}$ (Turniak et al. 2014) of the HBG was used to calculate its initial ${ }^{87} \mathrm{Sr} /{ }^{86} \mathrm{Sr}$ ratios and $\varepsilon \mathrm{Nd}(\mathrm{t})$ values. The isotopic ratios of the HBG and MMEs have narrow ranges. The HBG has initial ${ }^{87} \mathrm{Sr} /{ }^{86} \mathrm{Sr}$ values ranging from 0.7070 to 0.7094 (with a mean value of 0.7082$),{ }^{143} \mathrm{Nd} /{ }^{144} \mathrm{Nd}$ values ranging from 0.51198 to 0.51213 (with a mean value of 0.51208$)$, and $\varepsilon \mathrm{Nd}(\mathrm{t})$ values ranging from -5.43 to -2.39 (with a mean value of -3.47). The initial Sr ratio obtained by Pin et al. (1989) is 0.7098 . The $\varepsilon \mathrm{Nd}$ factor given by Pin et al. (1988)

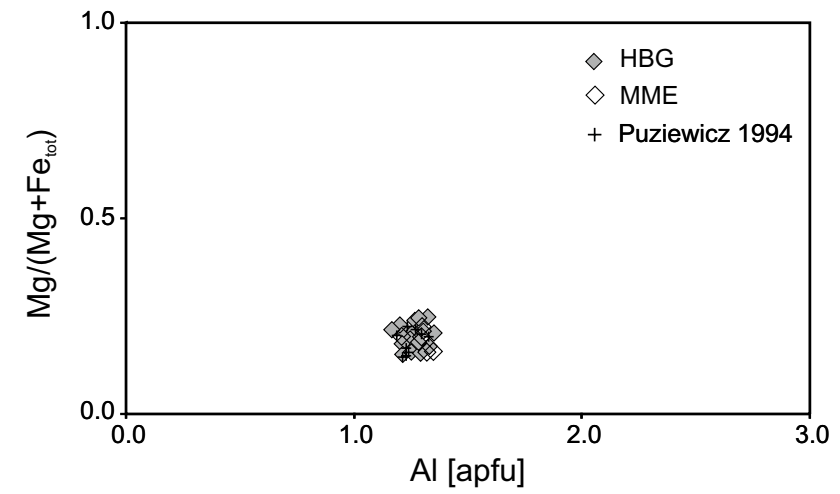

Fig. 7 Biotite chemistry of HBG and MMEs. Plot of the EMPA data in $\mathrm{Al}[\mathrm{apfu}] \mathrm{vs} \mathrm{Mg} /\left(\mathrm{Mg}+\mathrm{Fe}_{\text {tot }}\right)$ diagram

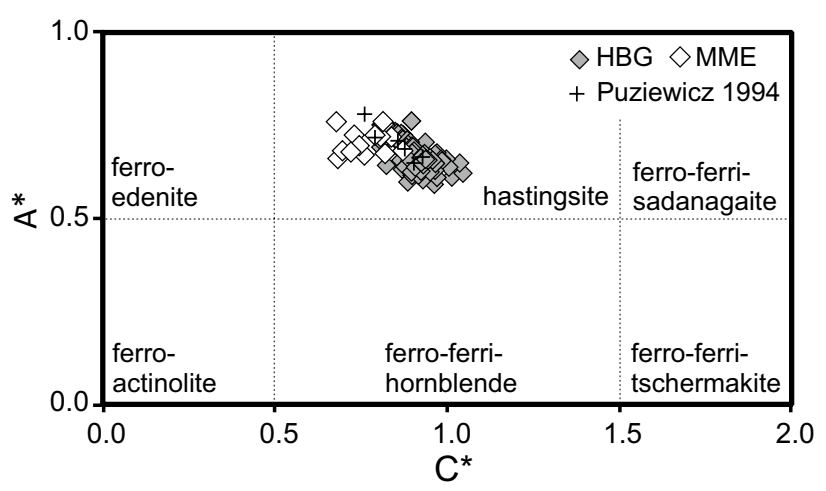

Fig. 8 Amphibole chemistry of HBG and MMEs. Plot of the EMPA data in the calcic amphibole classification diagram (Hawthorne et al. 2012). $A^{*}(\mathrm{Na}+\mathrm{K}+2 \mathrm{Ca}) ; \mathrm{C}^{*}\left(\mathrm{Al}+\mathrm{Fe}^{3+}+\mathrm{Cr}+2 \mathrm{Ti}\right)$

is -4.2 . MMEs have similar initial ${ }^{87} \mathrm{Sr} /{ }^{86} \mathrm{Sr}$ ratios (0.7079-0.7113; mean 0.7093), ${ }^{143} \mathrm{Nd} /{ }^{144} \mathrm{Nd}$ ratios

Table 4 Results of the major element-based geochemical modelling

\begin{tabular}{|c|c|c|c|c|c|c|c|c|c|}
\hline & $\begin{array}{l}\text { Parental magma } \\
\text { Co }\end{array}$ & $\begin{array}{l}\text { Differenti- } \\
\text { ated magma } \\
\mathrm{Cl}\end{array}$ & Plagioclase & Biotite & Amphibole & Magnetite & Ilmenite & Apatite & $\begin{array}{l}\text { Cumulate } \\
\text { composition } \\
\text { Cs }\end{array}$ \\
\hline $\mathrm{SiO}_{2}$ & 69.02 & 75.62 & 62.38 & 35.16 & 41.68 & 0.00 & 0.00 & 0.21 & 48.48 \\
\hline $\mathrm{TiO}_{2}$ & 0.60 & 0.14 & 0.00 & 4.28 & 2.26 & 7.53 & 49.89 & 0.00 & 2.02 \\
\hline $\mathrm{Al}_{2} \mathrm{O}_{3}$ & 14.30 & 13.29 & 23.58 & 12.78 & 8.65 & 5.74 & 0.00 & 0.00 & 17.34 \\
\hline $\mathrm{Fe}_{2} \mathrm{O}_{3}$ & 5.39 & 1.49 & 0.00 & 32.98 & 27.70 & 82.52 & 45.68 & 0.75 & 17.48 \\
\hline $\mathrm{MnO}$ & 0.10 & 0.04 & 0.00 & 0.53 & 0.30 & 0.00 & 4.43 & 1.10 & 0.24 \\
\hline $\mathrm{MgO}$ & 0.63 & 0.19 & 0.00 & 4.84 & 5.89 & 4.21 & 0.00 & 0.00 & 1.87 \\
\hline $\mathrm{CaO}$ & 1.91 & 1.05 & 5.25 & 0.00 & 10.41 & 0.00 & 0.00 & 54.98 & 4.66 \\
\hline $\mathrm{Na}_{2} \mathrm{O}$ & 3.87 & 3.53 & 8.62 & 0.22 & 1.90 & 0.00 & 0.00 & 0.22 & 5.12 \\
\hline $\mathrm{K}_{2} \mathrm{O}$ & 4.04 & 4.61 & 0.17 & 9.21 & 1.22 & 0.00 & 0.00 & 0.00 & 2.45 \\
\hline $\mathrm{P}_{2} \mathrm{O}_{5}$ & 0.15 & 0.04 & 0.00 & 0.00 & 0.00 & 0.00 & 0.00 & 42.75 & 0.35 \\
\hline \multicolumn{3}{|c|}{$\%$ of mineral phase in the cumulate } & 56.09 & 23.92 & 12.20 & 5.55 & 1.43 & 0.89 & \\
\hline \multicolumn{10}{|c|}{$\begin{array}{l}\text { Degree of } \mathrm{FC}=24.37 \% \\
R^{2}=0.007\end{array}$} \\
\hline
\end{tabular}

Mineral composition from HBG were used for mass-balance modelling 
Table 5 Concentrations of particular elements in the A, B magmas and the mixture $\mathrm{M}$

\begin{tabular}{|c|c|c|c|c|c|}
\hline Sample & $\begin{array}{l}C_{\mathrm{A}} \\
092\end{array}$ & $\begin{array}{l}C_{\mathrm{B}} \\
067\end{array}$ & $\begin{array}{l}C_{\mathrm{M}} \\
061\end{array}$ & $C_{\mathrm{A}}-C_{\mathrm{B}}$ & $C_{\mathrm{M}}-C_{\mathrm{B}}$ \\
\hline Locality & 9 & 7 & 6 & & \\
\hline \multicolumn{6}{|l|}{ wt. $\%$} \\
\hline $\mathrm{SiO}_{2}$ & 51.83 & 69.02 & 59.15 & -17.19 & -9.87 \\
\hline $\mathrm{TiO}_{2}$ & 1.47 & 0.60 & 1.17 & 0.88 & 0.57 \\
\hline $\mathrm{Al}_{2} \mathrm{O}_{3}$ & 16.77 & 14.30 & 15.32 & 2.48 & 1.03 \\
\hline $\mathrm{Fe}_{2} \mathrm{O}_{3}$ & 16.72 & 5.39 & 12.00 & 11.33 & 6.62 \\
\hline $\mathrm{MnO}$ & 0.48 & 0.10 & 0.22 & 0.38 & 0.12 \\
\hline $\mathrm{MgO}$ & 1.59 & 0.63 & 1.28 & 0.96 & 0.65 \\
\hline $\mathrm{CaO}$ & 2.63 & 1.91 & 2.97 & 0.72 & 1.06 \\
\hline $\mathrm{Na}_{2} \mathrm{O}$ & 4.38 & 3.87 & 4.17 & 0.52 & 0.30 \\
\hline $\mathrm{K}_{2} \mathrm{O}$ & 3.48 & 4.04 & 3.24 & -0.56 & -0.80 \\
\hline $\mathrm{P}_{2} \mathrm{O}_{5}$ & 0.63 & 0.15 & 0.47 & 0.48 & 0.32 \\
\hline \multicolumn{6}{|l|}{ ppm } \\
\hline $\mathrm{Co}$ & 7.10 & 12.20 & 9.00 & 11.70 & 15.30 \\
\hline Cs & 6.00 & 34.00 & 18.90 & 8.80 & 32.20 \\
\hline $\mathrm{Ga}$ & 23.80 & 44.40 & 31.50 & 31.20 & 37.10 \\
\hline $\mathrm{Hf}$ & 11.10 & 13.90 & 9.90 & 8.80 & 10.40 \\
\hline $\mathrm{Nb}$ & 34.50 & 114.80 & 72.70 & 67.00 & 92.70 \\
\hline $\mathrm{Rb}$ & 203.00 & 488.50 & 367.70 & 264.90 & 451.50 \\
\hline $\mathrm{Sr}$ & 85.30 & 74.50 & 89.40 & 103.60 & 68.70 \\
\hline $\mathrm{Ta}$ & 2.60 & 12.40 & 7.90 & 3.00 & 8.40 \\
\hline Th & 33.80 & 18.90 & 11.60 & 9.70 & 10.10 \\
\hline $\mathrm{U}$ & 6.30 & 25.60 & 5.50 & 3.40 & 7.20 \\
\hline $\mathrm{V}$ & 22.00 & 63.00 & 55.00 & 92.00 & 112.00 \\
\hline W & 1.10 & 7.50 & 0.80 & 1.40 & 1.30 \\
\hline $\mathrm{Y}$ & 47.00 & 102.90 & 77.20 & 69.80 & 198.00 \\
\hline $\mathrm{La}$ & 92.80 & 39.30 & 42.50 & 44.10 & 34.70 \\
\hline $\mathrm{Ce}$ & 185.40 & 78.70 & 100.50 & 95.70 & 100.40 \\
\hline $\operatorname{Pr}$ & 19.71 & 9.77 & 12.23 & 11.39 & 16.19 \\
\hline $\mathrm{Nd}$ & 67.80 & 41.30 & 49.70 & 50.10 & 82.60 \\
\hline $\mathrm{Sm}$ & 10.30 & 10.60 & 11.20 & 11.50 & 23.40 \\
\hline $\mathrm{Eu}$ & 0.92 & 0.51 & 0.81 & 1.02 & 1.20 \\
\hline $\mathrm{Gd}$ & 7.90 & 13.13 & 11.02 & 12.06 & 28.10 \\
\hline $\mathrm{Tb}$ & 1.39 & 2.31 & 1.95 & 2.09 & 5.33 \\
\hline Dy & 7.49 & 15.02 & 11.89 & 11.19 & 32.75 \\
\hline Ho & 1.42 & 2.75 & 2.05 & 2.33 & 5.87 \\
\hline $\mathrm{Er}$ & 3.95 & 7.89 & 6.11 & 6.02 & 16.60 \\
\hline $\mathrm{Tm}$ & 0.62 & 1.21 & 0.91 & 0.83 & 2.55 \\
\hline $\mathrm{Yb}$ & 4.26 & 8.21 & 6.20 & 5.47 & 17.24 \\
\hline $\mathrm{Lu}$ & 0.65 & 1.19 & 0.87 & 0.74 & 2.41 \\
\hline
\end{tabular}

Localities as in Table 1

$(0.51202-0.51213$; mean 0.51207$)$ and $\varepsilon N d(t)$ values $(-4.51$ to -2.50 ; mean -3.62$)$. There are no significant isotopic differences between the HBG and MME samples (Fig. 13).
The depleted mantle model ages [ $T_{\mathrm{DM}}$, depleted mantle model; DePaolo 1981; DePaolo and Wasserburg (1976)] are used to estimate the average crustal residence ages of the source materials. The $T_{\mathrm{DM}}$ and $\varepsilon \mathrm{Nd}$ values at $298 \mathrm{Ma}$ are shown in Table 3 and Fig. 14. The model ages $\left(T_{\mathrm{DM}}\right)$ range from 0.9 to $1.33 \mathrm{Ga}$ for the $\mathrm{HBG}$ and from 1.09 to $2.38 \mathrm{Ga}$ for MMEs. The $\varepsilon \mathrm{Nd}$ values are relatively constant for the HBG and vary from 5.11 to 5.96 (with a mean value of 5.33). The MME samples have lower $\varepsilon \mathrm{Nd}$ values, ranging from 2.76 to 5.51 (with a mean value of 4.08 ).

\section{Discussion}

\section{Mechanism of magma evolution: geochemical modelling}

As mentioned above, not all elements show consistent linear trends for the HBG and MMEs on $\mathrm{SiO}_{2}$-dependent variation diagrams within two individual populations, separately for granite and MMEs (Fig. 10). Some trends for trace elements break down at the transition between granite and enclave. Additionally, on the $\left(\mathrm{Na}_{2} \mathrm{O}+\mathrm{K}_{2} \mathrm{O}\right) / \mathrm{CaO}$ vs $\mathrm{Al}_{2} \mathrm{O}_{3}$ plot (Fig. 9), the HBG and MMEs clearly indicate different trends. This result implies that at least two different processes or two different paths of granite and enclave evolution occurred. Since this difference between trends may reflect different paths of geochemical evolution, the petrogenetic modelling of these two data suites was performed separately.

\section{Differentiation of the granitic melt}

As major elements behave similarly during fractional crystallization and partial melting, some trace elements were used to recognize the differentiation-causing process. The contents of incompatible elements should remain constant during fractional crystallization or slightly increase in the melt. Decreasing contents of compatible elements result in steep trends. In contrast, partial melting results in horizontal or sub-horizontal trends due to the opposite behaviours of compatible and incompatible elements (Cocherie 1986). The logarithmic diagrams of the most compatible elements (e.g., $\mathrm{Zr}$ and $\mathrm{V}$ ) versus the most incompatible elements (e.g., $\mathrm{Rb}$ ) show sub-vertical trends for the HBG (Fig. 15). This trend supports the view that the evolution of granite was mainly controlled by fractional crystallization. Additionally, decreasing contents of $\mathrm{Fe}_{2} \mathrm{O}_{3}, \mathrm{MgO}, \mathrm{CaO} \mathrm{TiO}_{2}, \mathrm{MnO}$, $\mathrm{Sr}$, Eu and $\mathrm{V}$ with increasing $\mathrm{SiO}_{2}$ (see Harker diagrams, Fig. 10) may reflect the fractionation of biotite, amphibole, plagioclase and Ti-bearing minerals (e.g., ilmenite and titanite). The decreasing $\mathrm{P}_{2} \mathrm{O}_{5}$ contents and negative $\mathrm{P}$ anomalies observed on the spidergrams (Figs. 10,12) reflect apatite fractionation. 
Fig. 9 Discrimination diagrams for $\mathrm{HBG}$ and MMEs: a $\mathrm{Al}_{2} \mathrm{O}_{3} /\left(\mathrm{Na}_{2} \mathrm{O}+\mathrm{K}_{2} \mathrm{O}\right)$ vs $\mathrm{Al}_{2} \mathrm{O}_{3} /$ $\left(\mathrm{CaO}+\mathrm{Na}_{2} \mathrm{O}+\mathrm{K}_{2} \mathrm{O}\right)$ molar diagram (after Maniar and Piccoli 1989); b $\mathrm{K}_{2} \mathrm{O}$ vs $\mathrm{SiO}_{2}$ diagram (after Rickwood 1989); c $\left(\mathrm{Na}_{2} \mathrm{O}+\mathrm{K}_{2} \mathrm{O}\right)$ vs $\mathrm{SiO}_{2}$ diagram (after Irvine and Baragar 1971); d $\left(\mathrm{Na}_{2} \mathrm{O}+\mathrm{K}_{2} \mathrm{O}-\mathrm{CaO}\right)$ vs $\mathrm{SiO}_{2}$ diagram (after Frost et al. 2001)
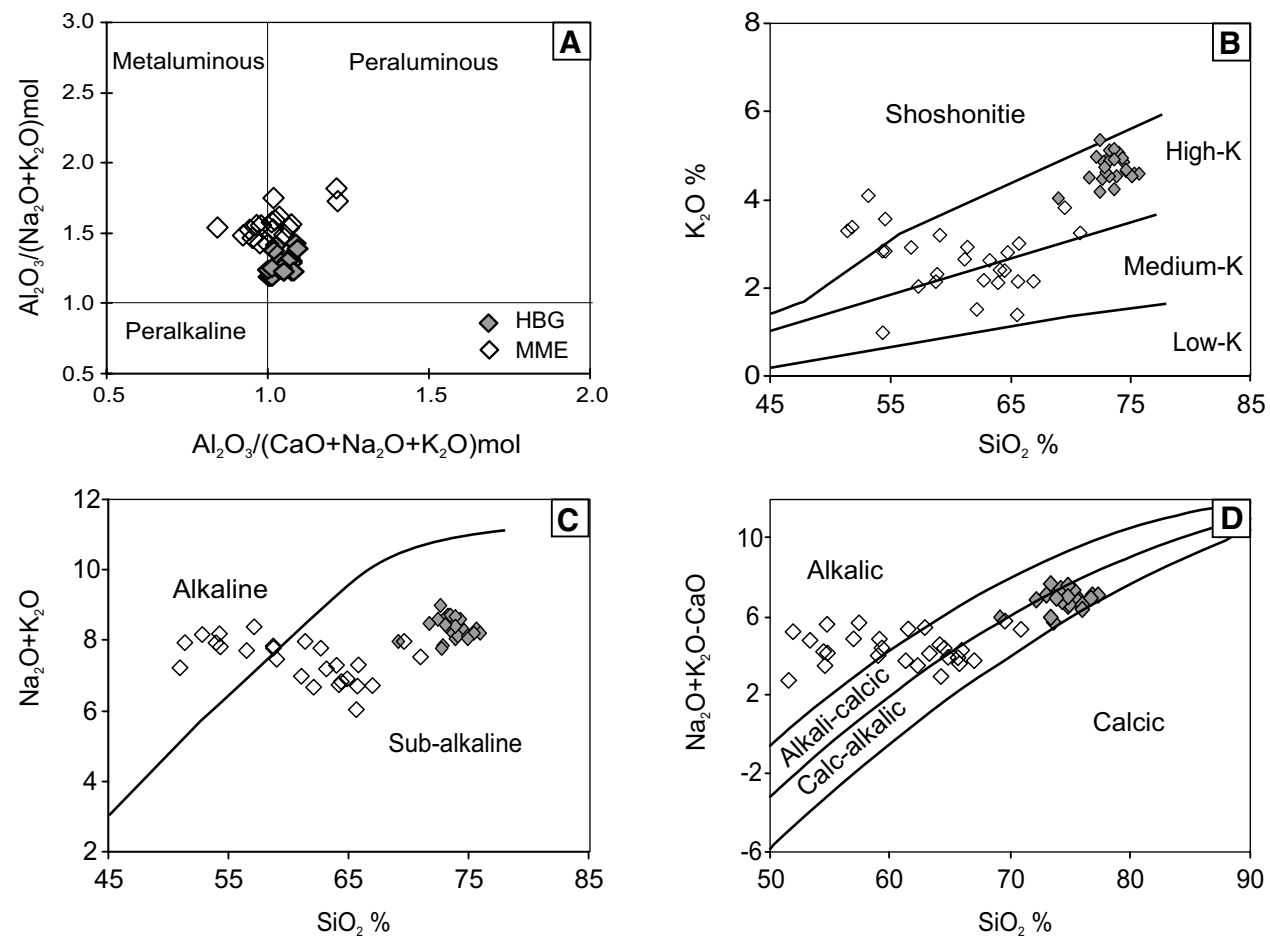

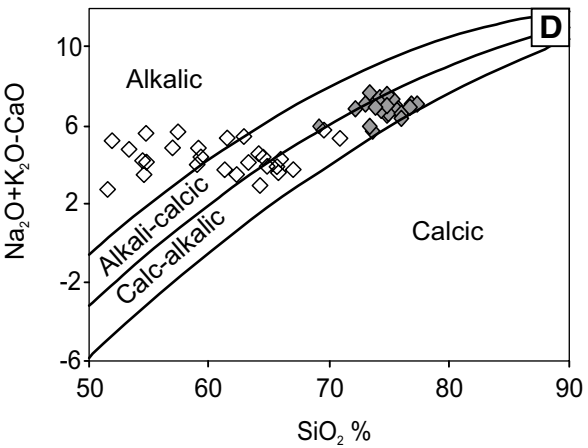

For this reason, fractional crystallization was modelled to reconstruct the differentiation of the high-silica $(\sim 75 \%$ wt. $\% \mathrm{SiO}_{2}$ ) melts derived from those with lower silica contents $\left(\sim 69 \%\right.$ wt. $\left.\% \mathrm{SiO}_{2}\right)$. All major elements are defined by straight, linear trends, indicating the constant chemical and modal compositions of the cumulate and a small degree of differentiation. The first stage of modelling involved mass balance calculations (Stormer and Nicholls 1978) based on major element contents to determine the modal and chemical compositions of the cumulate and the degree of fractional crystallization. These calculations were executed using the assumption that the magmatic system was closed. To model fractional crystallization, the most differentiated sample with the highest silica content was taken as the composition of the most differentiated melt, whereas the most silica-poor sample was taken as the initial melt composition. The input data used for modelling, as well as the modelling results, are shown in Table 4 . The best fit $\left(R^{2}=0.007\right)$ was obtained for a cumulate composed of $56.09 \%$ plagioclase, $23.92 \%$ biotite, $12.20 \%$ amphibole, $5.55 \%$ magnetite, $1.43 \%$ ilmenite and $0.89 \%$ apatite. The calculated degree of fractional crystallization was equal to ca. $24 \%$.

The obtained results were used for trace element modelling based on the equations of Rayleigh (1896) and the mineral/liquid partition coefficients $\left(\mathrm{KD}_{\mathrm{m} / \mathrm{l}}\right)$ that are typical for silica-rich melts (Table 9, supplementary material). The contents of the accessory phases, which are responsible for the observed behaviour of REEs, were used during this modelling step. By comparing the concentrations of particular trace elements in the rock with the most evolved composition $\left(\mathrm{Cl}_{\text {real }}\right)$ with the contents obtained from the modelling $\left(\mathrm{Cl}_{\text {calc }}\right)$, the major element modelling data were tested. The best fit was attained by adding zircon $(0.05 \%)$, monazite $(0.045 \%)$ and allanite $(0.005 \%)$ to the cumulate. Although slight differences between the real and calculated $\mathrm{Cl}$ values were observed in the HREEs (Dy and Er) and HFSEs (e.g., $\mathrm{Nb}$, Ti and $\mathrm{Y}$ ), as well as the transition metals ( $\mathrm{Co}$ and $\mathrm{Ni}$ ), the match between the calculated lines $\left(\mathrm{Cl}_{\text {calc }}\right)$ and analytical data $\left(\mathrm{Cl}_{\text {real }}\right)$ is satisfactory (Fig. 16).

\section{Differentiation of the mafic melt}

The Harker diagrams for the enclaves and granite do not show consistent, linear trends, which precludes a common mechanism of mafic-felsic magma evolution, i.e., neither fractional crystallization nor mixing. In turn, the textures found in MMEs (e.g., feldspar xenocrysts with disequilibrium textures inside MMEs, quartz ocelli, miaroles filled with quartz, and acicular apatite; Figs. 3,4 ) point at least to local interactions of mafic blobs with felsic melt. The MMEs hosted in the HBG are generally highly dispersed, and their relative sizes are too small to effectively change the composition of the granitic melt. On the other hand, the felsic melt strongly influenced the still plastic (not fully crystallized) mafic melt. We assumed that hybridization took place at the very beginning of the granitic magma evolution. The bends in the trends on Harker diagrams occur where the enclave data and granite populations come 

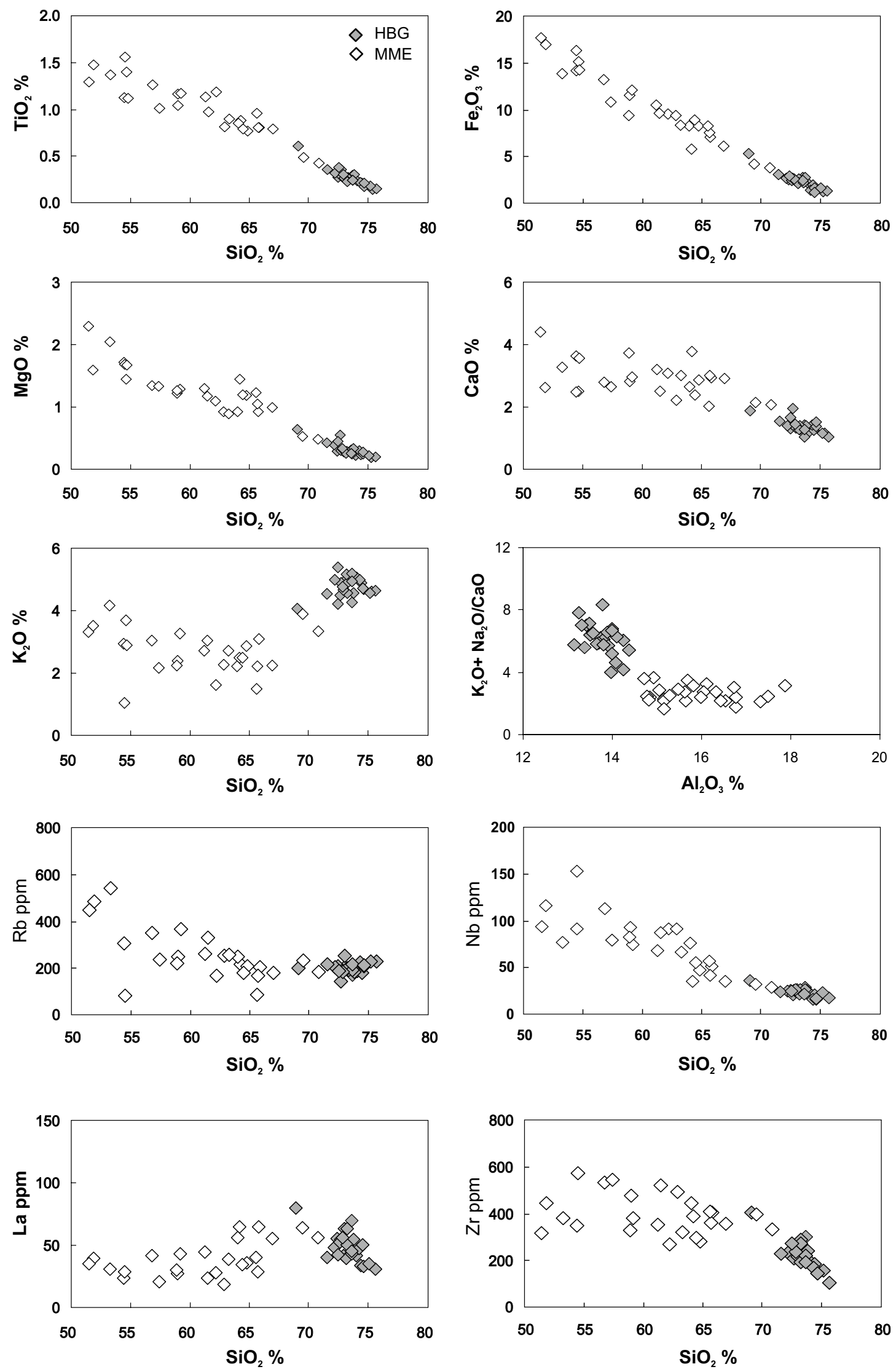

Fig. 10 Selected variation of major and trace element compositions vs silica (wt.\%) for whole-rock samples of HBG and MMEs 


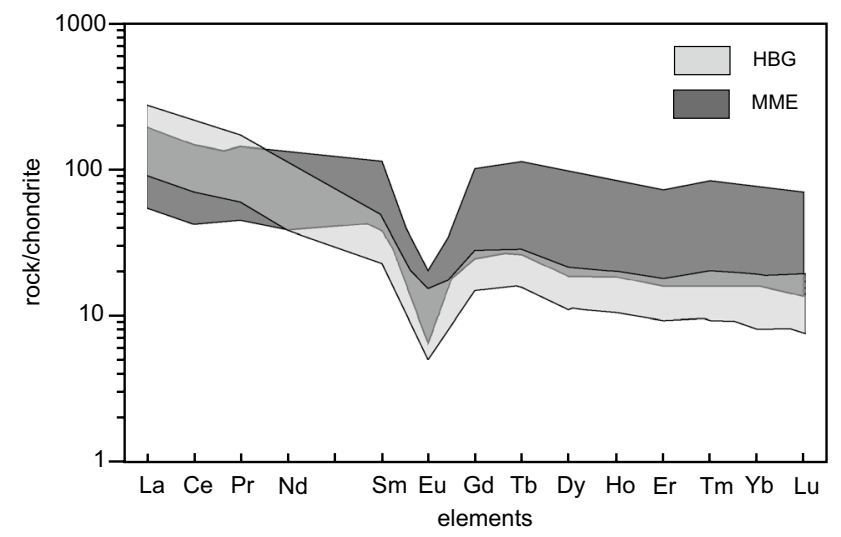

Fig. 11 The chondrite-normalized (Nakamura 1974) rare-earth element patterns for HBG and MMEs

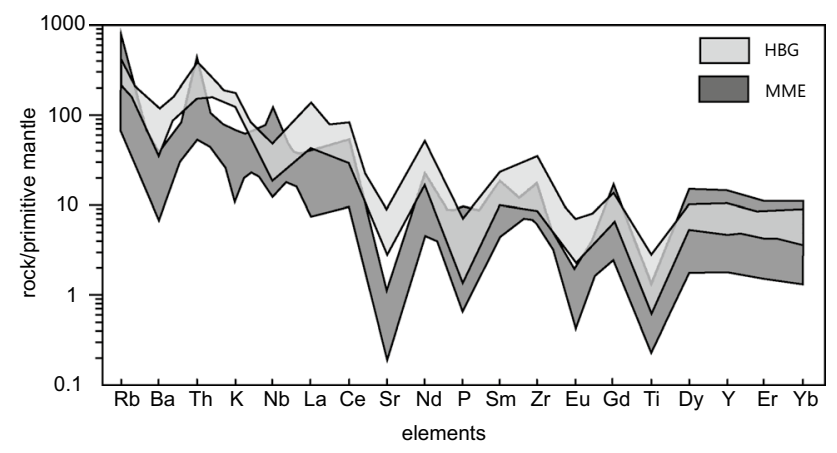

Fig. 12 Primitive mantle-normalized (Sun and McDonough 1989) trace element patterns for HBG and MMEs

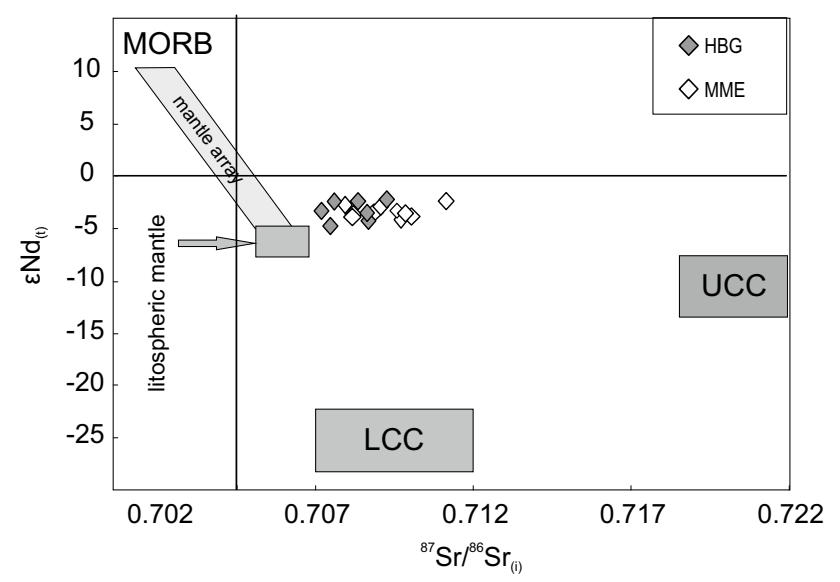

Fig. $13{ }^{87} \mathrm{Sr}^{86} \mathrm{Sr}_{(\mathrm{i})}$ vs $\varepsilon \mathrm{Nd}_{(\mathrm{t})}$ diagram for the HBG and MMEs

into contact. MMEs form consistent trends over a wide range of silica contents (from 51 to $70 \%$ ), and some dispersion is observed only within the samples with the lowest silica content. For this reason, we created and assessed

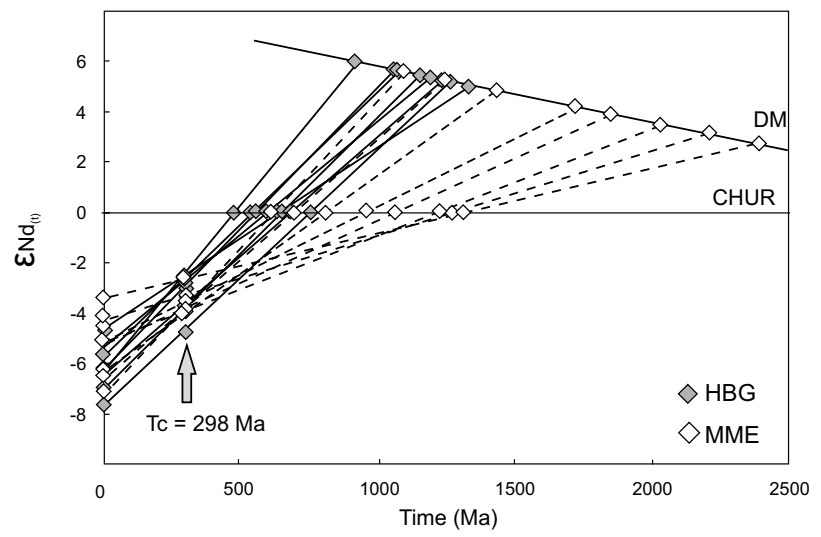

Fig. 14 The depleted mantle model ages for the HBG and MMEs

the magma mixing model assuming that the granitic melt in the earliest stage of evolution (with the lowest silica content) could modify the primary enclave composition.

Since the behaviours of major and trace elements during magma mixing are identical, joint geochemical modelling was performed for both element groups. In this modelling, the equation of the mass equilibrium law was used: $C_{\mathrm{M}}=X_{\mathrm{A}} C_{\mathrm{A}}+\left(1-X_{\mathrm{A}}\right) C_{\mathrm{B}}$, where $X_{\mathrm{A}}=\left(1-X_{\mathrm{B}}\right)$ (Fourcade and Allegre 1981). The least differentiated granitoid sample (69.02 wt.\% $\mathrm{SiO}_{2}$ ) was taken as the $C_{\mathrm{B}}$ magma composition (Table 5). This sample was treated as a felsic contaminant of the mafic melt. The MME with the lowest silica content (51.83 wt.\% $\mathrm{SiO}_{2}$ ) was assumed to represent the $C_{\mathrm{A}}$ magma. As the mixing product of the two magmas, $C_{\mathrm{M}}$ was assumed to indicate the MME containing $59.15 \mathrm{wt} . \% \mathrm{SiO}_{2}$.

On the $\left(C_{\mathrm{M}}-C_{\mathrm{B}}\right)-\left(C_{\mathrm{A}}-C_{\mathrm{B}}\right)$ diagram, all of the points representing major and trace elements lie on the straight line crossing the centre of the coordinate axes $(0 ; 0)$ (Fig. 17). The equation of this line is $y=0.61 x-2.74$, where the value of 0.61 (line gradient) represents the amount of the contaminant $C_{\mathrm{B}}$. Thus, the proportions of the felsic and mafic melts in the mixture were ca. $61 \%$ and $39 \%$, respectively.

The very low sum of squared residuals testifies in favour of the model $\left(R^{2}=0.9676\right)$. The rock samples chosen for the modelling fit the best-defined trend (Fig. 17). However, not all MME samples used in the modelling yield such ideal results. In particular, the rocks with the lowest differentiation index tend to deviate from the established trend. This feature may suggest that the process could have been more complex than simple two end-member magma mixing and might have occurred at a different stage of intrusion formation.

\section{Source characteristics and origins of magmas of the HBG and MMEs}

Most petrologists consider that granitoids have three possible origins: a crust-derived origin, mantle-derived origin 
Fig. $15 \log$ (compatible element) vs $\log$ (incompatible element) plot after Cocherie (1986) for the HBG. $P M$ partial melting trend, $F C$ fractional crystallization trend
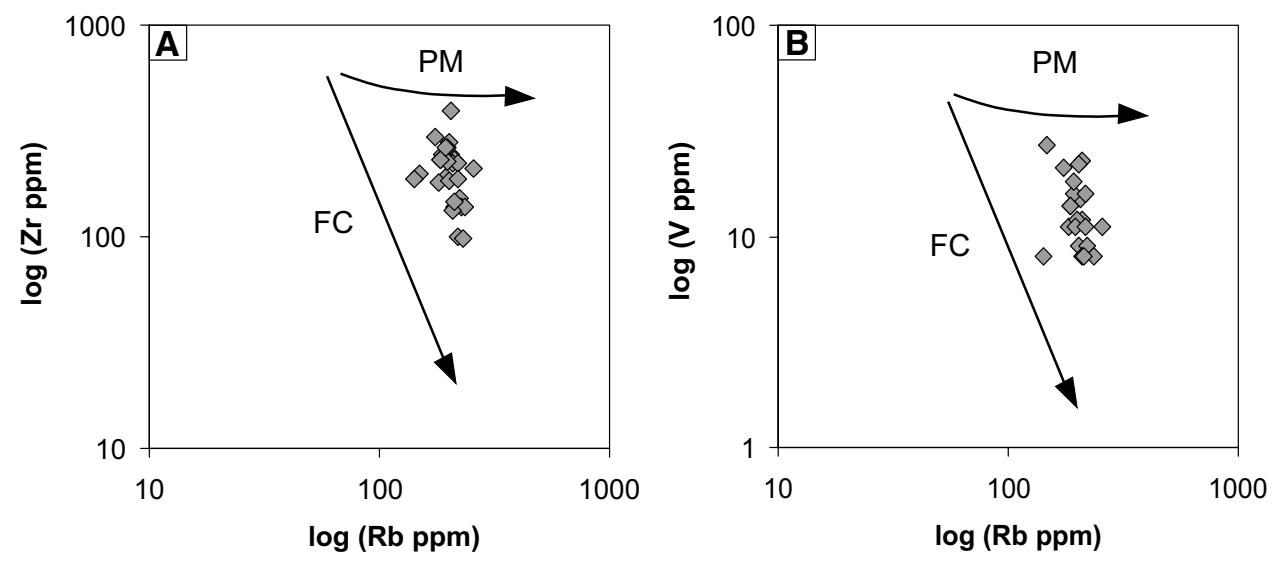

Fig. 16 a The chondritenormalized REE patterns (Nakamura 1974) and b primitive mantle-normalized trace element patterns (Sun and McDonald 1989) illustrating the results of fractional crystallization modelling (bold line). The partition coefficients used in model are given in Table 9, supplementary material
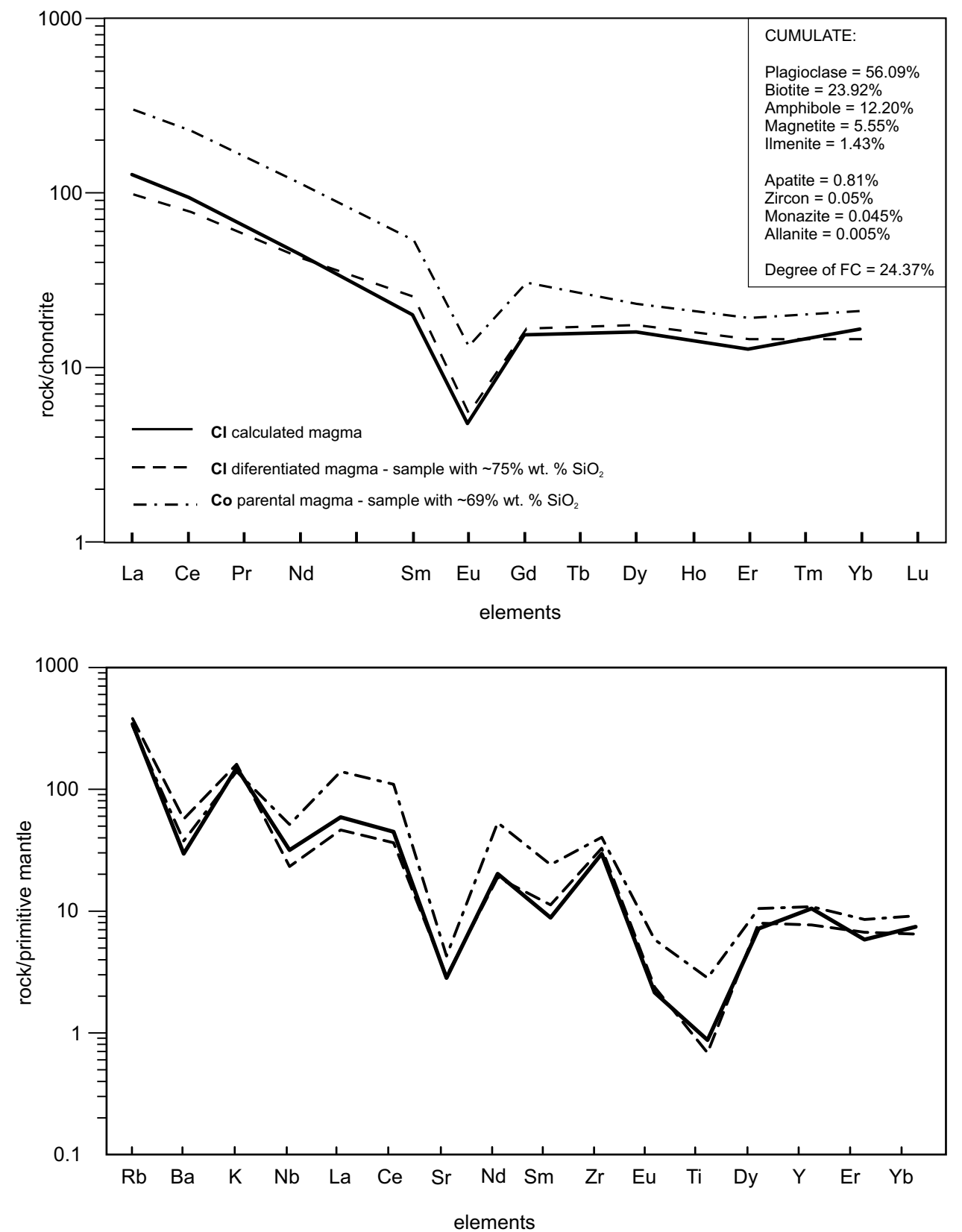


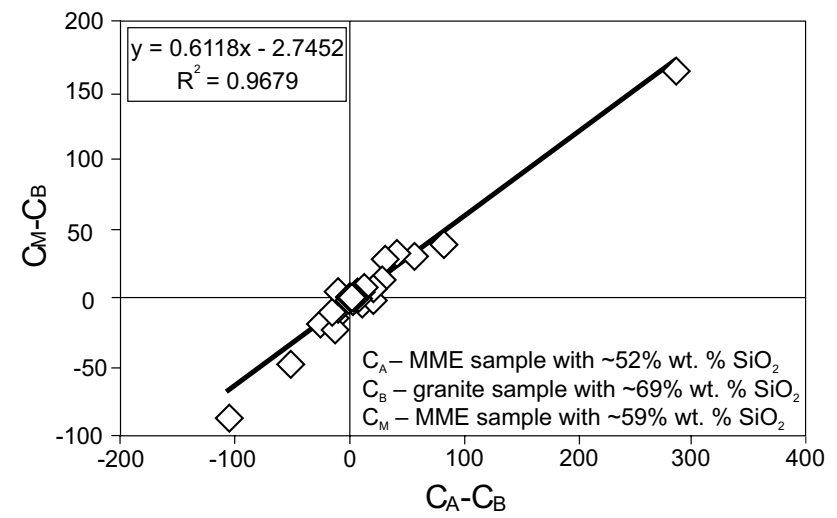

Fig. 17 Major and chosen trace elements mixing test (Fourcade and Allegre 1981) for MMEs

or mixed origin that involves both crust- and mantle-derived melts. To identify the origin of the magmas contributing to pluton formation, phase and geochemical indices are used. In the latter, in the case of the HBG, ambiguity is clearly visible. The discussion of this problem and the clarification of the ambiguity is very important because the majority of Variscan plutons in the Sudetic section of the European Variscides are of mixed mantle-crust origin (Finger et al. 1997; Žák et al. 2013). Furthermore, some magma chambers within the SSM are clearly assigned to magmas originated from two sources, the mantle and the crust.

Some mineral parageneses and rock textures of the HBG from the SSM suggest that the granite probably represents a K-rich calc-alkaline granitoid (KCG), which is a subtype of calc-alkaline granitoids in the classification proposed by Barbarin (1999). The dominant mafic mineral in the HBG is biotite. The K-feldspar porphyritic texture and the composition of plagioclase (An\% ranging from 15 to 40) are consistent with the KCG characteristics. However, neither the mineral association nor rock textures ultimately determine the origin of magma. For the KCG, Barbarin (1999) assumed mantle and crustal magma sources; in contrast, Roberts and Clements (1993) argued that K-rich calc-alkaline granitoids do not necessarily need such sources but can originate solely from crustal magmas. The inference of the KCG type is consistent with the geochemical features of the HBG, such as its calc-alkalic and $\mathrm{K}_{2} \mathrm{O}$-rich characteristics, low $\mathrm{Mg}$ number (0.15-0.30) and weakly peraluminous composition (Fig. 10). The obtained isotopic compositions fit with the range proposed by Barbarin (1999). Nevertheless, several indicators contradict Barbarin's (1999) hypothesis of mantle-crust sources of magma and provide some evidence in favour of Roberts and Clements's (1993) hypothesis, i.e., for the origin of magma from only a crustal source.

$\mathrm{Nb} / \mathrm{Ta}$ ratios can be used to indicate the source of magma. The average $\mathrm{Nb} / \mathrm{Ta}$ ratios of crust-derived magmas are

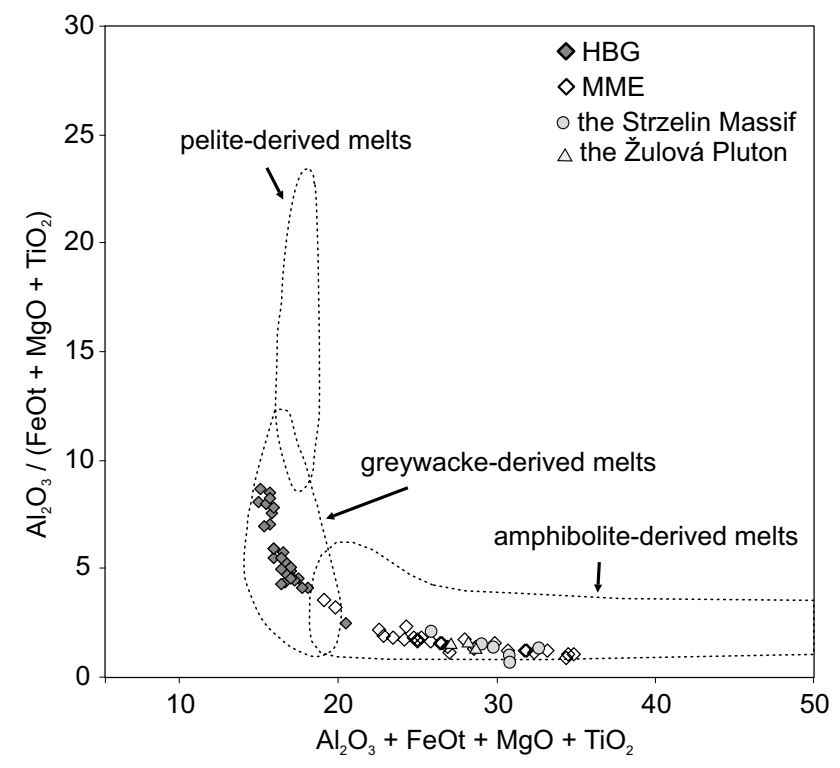

Fig. 18 The $\mathrm{Al}_{2} \mathrm{O}_{3}+\mathrm{FeO}_{\mathrm{t}}+\mathrm{MgO}+\mathrm{TiO}_{2}$ vs $\mathrm{Al}_{2} \mathrm{O}_{3} /$ $\left(\mathrm{FeO}_{\mathrm{t}}+\mathrm{MgO}+\mathrm{TiO}_{2}\right)$ diagram for $\mathrm{HBG}$ and MMEs discriminates between anatectic melts from metapelites, metagreywackes and amphibolites protoliths. Domains obtained from Patiño Douce (1999), summarized by Jung et al. (2009). For comparison diorite samples from the Strzelin Massif and the Žulová Pluton (data from Pietranik and Waight 2008; Laurent et al. 2014)

approximately 12 , but the values vary from approximately 8 for the lower crust to 16 for the middle crust and 13 for the upper crust (Rudnick and Gao 2003). The Nb/Ta ratios of mantle-derived magmas are 14-17 (Green 1995; Palme and O'Niell 2014). The Nb/Ta ratios of the HBG are variable over a wide range of 5.6-15.6. Thus, these values are not indicative because their variability encompasses the ranges for both crust- and mantle-derived magmas. Thus, the sources of granitic magma remain unclear.

The $\mathrm{Al}_{2} \mathrm{O}_{3}+\mathrm{FeOt}+\mathrm{MgO}+\mathrm{TiO}_{2}$ vs $\mathrm{Al}_{2} \mathrm{O}_{3} /$ $\left(\mathrm{FeOt}+\mathrm{MgO}+\mathrm{TiO}_{2}\right)$ diagram proposed by Patiño Douce (1999) can be used to discriminate between anatectic melts from metapelite, metagreywacke and amphibolite (metaigneous) protoliths. The data points for the HBG plot in the field of partial melts of metagreywackes (Fig. 18).

The $\mathrm{CaO} / \mathrm{Na}_{2} \mathrm{O}$ ratio may also be used to distinguish between metapelitic (plagioclase poor) and metagreywacke (plagioclase rich) sources (Sylvester 1998). Pelite-derived granite melts tend to have lower $\mathrm{CaO} / \mathrm{Na}_{2} \mathrm{O}$ ratios $(<0.3)$ than greywacke-derived granite melts $(>0.3)$. The HBG records $\mathrm{CaO} / \mathrm{Na}_{2} \mathrm{O}$ ratios between 0.30 and 0.59 with a mean value of 0.39 ; these values are thus more closely related to a greywacke source. It is also possible that granites with high $\mathrm{CaO} / \mathrm{Na}_{2} \mathrm{O}$ ratios (such as the $\mathrm{HBG}$ ) can be derived from a gneissic rather than a greywacke source (Miller 1985). A gneiss source for the HBG was advanced by Majerowicz (1972); however, Kennan et al. (1999) excluded a gneiss 
protolith based on a review of published $\mathrm{Rb}-\mathrm{Sr}$ isotope data for Variscan granites in this part of the Bohemian Massif. Given isotopic composition data obtained by Pin et al. (1989), Puziewicz (1990) suggested metapelite, greywacke or acidic volcanic rock as potential sources for the HBG and proposed that the source of this melt was located in the eastern prolongation of the Kaczawa Unit rock suite, which is composed of a Cambrian to Lower Carboniferous metavolcanic-metasedimentary succession (Baranowski et al. 1990; Kryza and Muszyński 1992; Kryza and Zalasiewicz 2008). The melting of metapelitic rocks, however, would produce magma with a strongly peraluminous signature (e.g., Miller 1985), while the HBG shows only a weakly peraluminous composition. The $\mathrm{Nb} / \mathrm{Ta}$ ratios for metagreywacke protoliths are variable and depend on the composition of the lithoclasts. For example, Devonian greywackes from the Rhenohercynian zone have ratios close to 10 (Floyd et al. 1991). Additionally, the temperature of the HBG magma probably exceeded $850{ }^{\circ} \mathrm{C}$ (Puziewicz 1990; Turniak et al. 2014), which is consistent with the melting of a metagreywacke protolith and could produce a sufficient amount of melt to form a granitic pluton (Johannes and Holtz 1996).

The isotope composition of the HBG shows relatively high ${ }^{87} \mathrm{Sr}^{86} \mathrm{Sr}_{(\mathrm{i})}$ ratios from 0.7070 to 0.7094 with a mean value of 0.7082 and low $\varepsilon \mathrm{Nd}(\mathrm{t})$ values $(-5.43$ to -2.39$)$. These data are consistent with the isotopic investigation presented by Pin et al. (1989). The authors note the high isotopic variability of the Strzegom massif, including the HBG itself. They determined the following ${ }^{87} \mathrm{Sr}^{86} \mathrm{Sr}_{(\mathrm{i})}$ ratios: 0.7098 for hornblende-biotite granite, 0.7082 for biotite granite, 0.7058 for biotite granodiorite and 0.705 for twomica granite. This diversity has probably been inherited from protoliths of various compositions. Thus, the isotopic data may implicate mixing of magmas from various crustal sources but does not explicitly indicate a mixed crust and mantle source for the granite. Therefore, the role of the mantle in the process of melt generation could be confined to providing heat, causing/enhancing the melting of the protolith/protoliths. However, the influence of the enriched mantle could also be related to mantle-derived fluids supporting the melting processes (Martin and De Vito 2005; Martin 2006). The influence of such fluids on the HBG may be demonstrated by the abundance of NYF miarolitic pegmatites (Pieczka et al. 2015 and references therein). The NYF signature would indicate a long-term influence of mantle-derived fluids on granite evolution. Thus, although the direct participation of mantle melt cannot be unambiguously confirmed, the indirect participation of the mantle in the formation of HBG and MMEs seems to be documented by concentrations of some trace elements as well as the geochemical characteristics of the host pegmatites.

The lack of unambiguous indicators for the participation of mantle melt opens the discussion to the possibility of forming the HBG with the participation of only crustal material. Assuming crustal sources for granitic magma, the magma was emplaced as homogeneous molten matter into the chamber and further differentiated by fractional crystallization. The geochemical variations in the low- to high-SiO samples likely resulted from the fractionation of plagioclase, biotite, and amphibole (see geochemical modelling results, Table 4). On primitive mantle-normalized spidergrams, the HBG samples are characterized by pronounced negative Ba, $\mathrm{Nb}, \mathrm{Sr}, \mathrm{P}, \mathrm{Eu}$ and $\mathrm{Ti}$ anomalies but are enriched in $\mathrm{Rb}, \mathrm{Th}, \mathrm{K}$ and $\mathrm{La}$. These negative anomalies may reflect the fractionation of plagioclase, apatite, and $\mathrm{Fe}-\mathrm{Ti}$ oxides during some stages of magma evolution (Fig. 12). Additionally, the $\mathrm{SiO}_{2}$ content increases with decreasing $\mathrm{MgO}, \mathrm{Fe}_{2} \mathrm{O}_{3}, \mathrm{CaO}$ and $\mathrm{TiO}_{2}$ and $\mathrm{P}_{2} \mathrm{O}_{5}$ contents (Fig. 10), further suggesting the fractionation of these mineral assemblages.

MMEs in the KCG-type rocks are considered evidence of magmas from a mantle source; thus, MMEs confirm the composite nature of a pluton (Barbarin 1999, 1991, 2005, 1991; Didier 1973; Castro et al. 1990; Vernon 1984, 1990, 2010; Frost and Mahood 1987; Didier and Hibbard 1991; Orsini et al. 1991; Wiebe et al. 1997; Gerdes and Wörner 2000; Słaby and Götze 2004; Słaby and Martin 2008; Pietranik and Koepke 2009, 2014). However, this situation is not the case for the HBG because the geochemical models show that the MMEs did not influence the evolution of the granitic melt to a significant extent. In addition, although some enclave margins do exhibit local hybridization, their chemical and isotopic compositions cannot be directly related to a mantle source. A question arises as to whether the enclaves are also entirely of crustal origin or are products of the interaction of melts derived from the crust and mantle. Since their geochemical indicators are ambiguous and do not directly point to the participation of the mantle in their formation, their origin may be exclusively crustal, as suggested by the Roberts and Clements hypothesis (1993).

The existence of spheroidal dark enclaves and their petrological characteristics suggest their apparent emplacement before solidification and thus limited mafic-felsic magma interactions (Vernon 1984; Castro et al. 1990; Orsini et al. 1991; Kumar and Rino 2006; Słaby and Martin 2008; Chen et al. 2009; Kocak et al. 2011; Pietranik and Koepke 2014; Zhang et al. 2016). The investigated MMEs show some textures, such as acicular apatite, plagioclase and K-feldspar xenocrysts with resorption surfaces, miaroles filled with quartz, ocellar quartz and mafic clots, that are compatible with magma mixing-mingling with the surrounding granite. However, the precondition for running the mixing/hybridization process is the compositional gradient between the two interacting substances, regardless of their sources of origin.

MMEs contain the same minerals as the HBG but in different proportions. Enclaves are mostly composed of plagioclase and biotite with minor interstitial $\mathrm{K}$-feldspar and 
quartz. Microprobe analyses and CL investigations indicate that the plagioclase laths forming the groundmass of MMEs are different from those in granite. In MMEs, the groundmass plagioclase cores are more calcic, and albitic compositions are less common than in the HBG. The cores also show different CL features. In contrast, the plagioclase phenocrysts occurring in MMEs display strong similarities to those in granite. Only the rims of the plagioclase phenocrysts incorporated in the MMEs show chemical similarities to the groundmass crystals, which may reflect equilibration between mafic and felsic melts. The K-feldspar phenocrysts from the HBG and associated MMEs show similar compositions and CL features. Therefore, we interpret the large crystals of plagioclase and K-feldspar inside the MMEs as xenocrysts that were probably mechanically introduced from the granitic host. Feldspars are very sensitive indicators of magmas interaction (Waight et al. 2000; Slaby and Goetze 2004; Słaby et al. 2007a, b, 2008; Pietranik and Waight 2008; Pietranik and Koepke 2014; Ubide et al. 2014; Michel et al. 2016). In this case, however, the interaction is highly limited and it cannot be precisely determined at which stage feldspars have been incorporated into the MMEs. The compositions of the biotites from the MMEs and HBG are nearly the same, which suggests that they achieved advanced chemical equilibration. Such equilibration is also reported by Puziewicz (1995).

The fact that the minerals forming the granitoid host and MMEs have similar but not identical compositions can be explained by chemical equilibration (Fernandez and Barbarin 1991). The efficiency of this process strongly depends on the size of the enclaves; small (a few centimetres) enclaves are quenched and display more mafic compositions, whereas larger ones (up to $1 \mathrm{~m}$ ) represent hybrid rocks with intermediate compositions. At the same time, these features exclude their having restite characteristics. We conclude that these enclaves represent globules of more mafic, generally hybrid magma that comingled with a more felsic host magma (Vernon 1983; Sparks and Marshall 1986; Castro et al. 1991; Barbarin and Didier 1992; Hawkesworth and Kemp 2006; Feeley et al. 2008; Chen et al. 2009; Kocak et al. 2011; Liu et al. 2013). The surrounding host magma had significant impacts on the chemistry of the relatively small volumes of the more mafic magma that were introduced into the granitic chamber. However, this interpretation raises the following question: what was the timing of this recharge, and from what source/place was the additional magma delivered? As mentioned above, evidence of interaction between enclaves and granite indicates only contact of molten materials with different compositions but does not provide an answer to the question about the origin of these molten materials.

The broad compositional range of MMEs, with $\mathrm{SiO}_{2}$ contents varying from $51-71 \mathrm{wt} . \%$ (Table 2), may indicate the magma mixing process, but was the mixing between crustal and mantle-derived magmas or between crustal magmas of different compositions? The Mg numbers of the MMEs are low and similar to those of the HBG (0.16-0.33). The MMEs have peraluminous and metaluminous compositions (A/CNK ratios: 0.85-1.22) (Fig. 9a). The MMEs show low $\mathrm{Ni}$ contents (up to $13 \mathrm{ppm}$ ), which are far below the Ni contents expected for a primitive basaltic magma derived from a mantle source ( $\mathrm{Ni}=250-300 \mathrm{ppm}$, e.g., Wilson 1989) and thus exclude a mantle source or any significant participation of mantle magma in MME formation. The low Mg numbers (less than 0.7, e.g., Wilson 1989) also indicate that even the most primitive enclave (with $51 \% \mathrm{SiO}_{2}$ ) had to have undergone fractionation processes or crustal contamination.

$\mathrm{The} \mathrm{Th} / \mathrm{Nb}$ ratio is a very sensitive indicator of mafic magma-crust interactions (Barth et al. 2000; Pearce 2008). On the $\mathrm{Nb} / \mathrm{Yb}$ vs $\mathrm{Th} / \mathrm{Yb}$ diagram (Fig. 19), almost all MMEs plot close to the upper crust field (similar to the HBG) and outside the mantle array. Enclaves approaching this trend may indicate a weak influence of the mantle source, perhaps manifested only in the presence of heat/fluids. The textural evidence that can support a fluid-rich environment may be dark reaction margins in the plagioclase grains visible on $\mathrm{CL}$ photos that are the result of introducing defects and $\mathrm{OH}$ groups into their structure (Słaby et al. 2012).

The potential impact of the mantle-derived fluids can additionally make the high trace element contents credible. The MMEs display high concentrations of large-ion

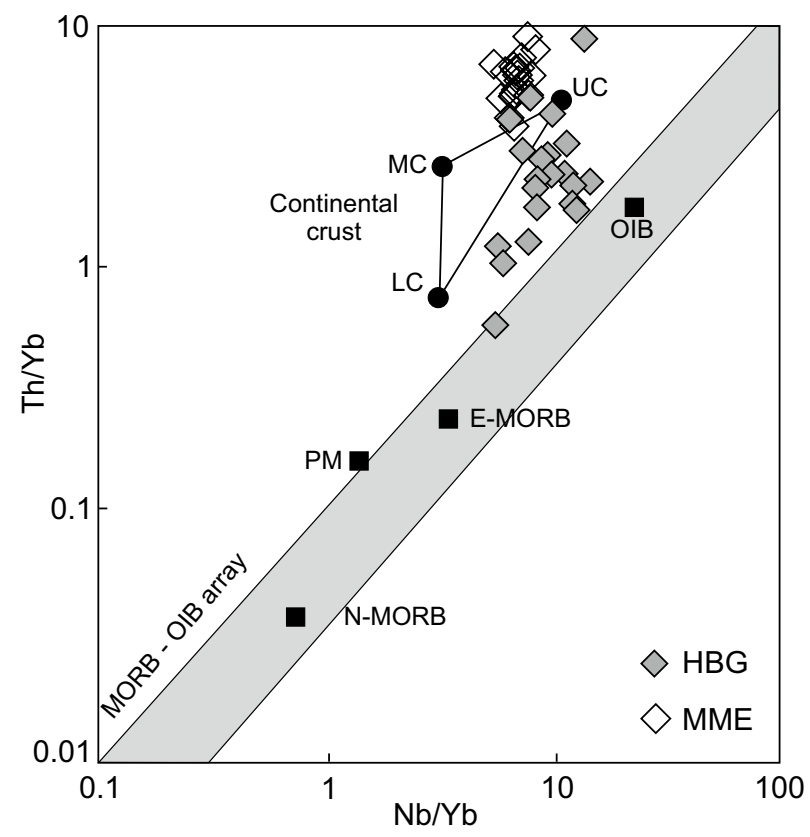

Fig. $19 \mathrm{Nb} / \mathrm{Yb}$ vs $\mathrm{Th} / \mathrm{Yb}$ diagram, after Pearce (2008). Average N-MORB, E-MORB, OIB are taken from Sun and McDonough (1989); average lower crust (LC), middle crust (MC), upper crust (UC) and total continental crust (CC) are selected from Rudnick and Fountain (1995) 
lithophile elements (LILEs) compared to the primitive mantle, as well as positive $\mathrm{Rb}$, Th, and $\mathrm{Sm}$ anomalies and negative $\mathrm{Nb}$ and $\mathrm{Ti}$ anomalies (Fig. 12).

The different protoliths of the MMEs and the $\mathrm{HBG}$ are supported by the $\mathrm{Al}_{2} \mathrm{O}_{3}+\mathrm{FeOt}+\mathrm{MgO}+\mathrm{TiO}_{2}$ vs $\mathrm{Al}_{2} \mathrm{O}_{3} /$ $\left(\mathrm{FeOt}+\mathrm{MgO}+\mathrm{TiO}_{2}\right)$ diagram (Fig. 18); the geochemistry of the enclaves indicates that they have an amphibolitic melt source, while the geochemistry of the HBG reflects the partial melting of greywacke material. In this case, the source of both magmas might be crustal.

The lower crust and upper crust are quite heterogeneous in their isotopic compositions and are not easily characterized by a single isotopic composition. In addition, initial $\mathrm{Sr}$ and $\mathrm{Nd}$ isotope studies of the lower crust (based on xenoliths) indicated that it has $\varepsilon \mathrm{Nd}$ similar to that of the upper crust and that the ${ }^{87} \mathrm{Sr} /{ }^{86} \mathrm{Sr}$ ratios of both environments are variable (Downes 1993; Rudnick 1992). In the case of the HBG, Nd and $\mathrm{Sr}$ isotopes are not effective discriminators between potential magma sources. The MMEs have initial ${ }^{87} \mathrm{Sr} /{ }^{86} \mathrm{Sr}$ ratios (with a mean value of 0.7093 ) and $\varepsilon \mathrm{Nd}(t)$ values (with a mean value of -3.62) (Fig. 13) similar to those of the HBG. We interpret this strong isotopic similarity as a result of complete isotopic equilibration during magma mixing at the emplacement level (Holden et al. 1987, 1991; Pin et al. 1990; Fourcade and Javoy 1991; Stephens et al. 1991; Barbarin and Didier 1992; Poli et al. 1996; Waight et al. 2001; Turnbull et al. 2010), which is more effective than geochemical equilibration (Lesher 1990). The lack of positive $\varepsilon \operatorname{Nd}(t)$ values even in the enclaves with the most primitive compositions suggests that the MMEs are hybrids that originated from the lower crust. The partial melting of amphibolitic lower crust could have been caused by the periodic influx of mantle heat/fluids and melts leading to successive contamination during their emplacement. The clear division of the HBG and MMEs into two distinct groups on the neodymium evolution diagram (Fig. 15) may indicate that their parental magmas had different sources. Therefore, the studied enclaves cannot be treated as "autoliths", i.e., portions of cumulate generated by the fractional crystallization of the granitic melt (Dodge and Kistler 1990; Lesher 1990; Donaire et al. 2005). MMEs, which plot within the same field as the HBG, are characterized by high-silica contents. These enclaves were highly contaminated by granitoid melt during the magma mixing-mingling process. Mixing models (see geochemical modelling, Fig. 17) indicate that the enclave compositions record granitic magma contents of up to $60 \%$.

\section{The tectonic setting}

The Sudetic granites can be divided into two groups with distinct emplacement ages of 340-330 Ma and 320-295 Ma (e.g., Mazur et al. 2007; Laurent et al. 2014). The older granites are related to the main stage of nappe stacking within the Central European Variscides (e.g., Franke 2000). The younger granites, such as the Strzegom-Sobótka Massif (as well as the Strzelin Massif and the Žulová Pluton), intruded into the cooled upper crust after the cessation of the Variscan orogeny. Turniak et al. (2014) suggested that the melt generation of the SSM was initiated by crustal heating due to the influx of basaltic magmas rising from the lithospheric mantle. The same mechanism was proposed by Pietranik and Waight (2008) for the Strzelin Massif ( 306-291 Ma) and by Laurent et al. (2014) for the Žulová Pluton ( 298-291 Ma) in the Sudetic domain of the Central European Variscides (Fig. 1). In contrast to the previously presented models, detailed research on the HBG does not point to the widespread direct participation of mantle melts in granitic magma generation. However, these models have defined the mantle role in a qualitative manner.

The neodymium model ages $\left(T_{\mathrm{DM}}\right)$ obtained for the $\mathrm{HBG}$ $(0.9-1.33 \mathrm{Ga})$ from the Strzegom-Sobótka Massif show a crustal residence age similar to that of the Strzelin Massif (1.09-1.46 Ga for bt-ms granite and tonalite samples; Oberc-Dziedzic et al. 2016; $1.3 \mathrm{Ga}$ for the Gęsiniec quartz diorite; Pietranik and Waight 2008) and the Žulová Pluton (1.18-1.30 Ga for granite and quartz monzodiorite samples; Laurent et al. 2014), which may confirm similar times but partly different mechanisms of generation for their parental melts.

The chemical compositions of the MMEs from the HBG, diorite samples from the Strzelin Massif and quartz diorite samples from the Žulová Pluton (data from Pietranik and Waight 2008; Laurent et al. 2014) appear to be compatible with the partial melting of intermediate metaigneous material, i.e., the crustal source. This interpretation would be in accord with our results (Fig. 18).

\section{Conclusion}

The HBG composing the western part of the Strzegom-Sobótka Massif is an example of an intrusion that formed in a multi-component system. The system shows ambiguous isotopic and geochemical signatures. The pluton appears to have a composite character. However, the melts responsible for the granitic rock formation and MMEs were derived from different crustal domains and afterwards were contaminated. These melts exhibit hybrid characteristics. The origins of both the granitic and MME hybrids cannot 
be explained by a two end-member system. This system was supplemented by other components, which influenced its isotopic signature. The main mechanism involved in developing granitic rocks was fractional crystallization (FC), but other local processes were involved in rock formation. Generally, the FC signature was not obscured by the input of the hybrid mafic melt. This felsic-mafic interaction was limited and can be viewed as one-sided. The influence of small-volume mafic magma blobs on granite crystallization was negligible. The massif is thus an ideal example of an environment where MMEs coexist with a granitic body; however, the MMEs do not determine the actual composite characteristics of the pluton. MMEs are not cognate with the granitoid magma. The data point to two different stages of the hybridization of two different magmas: one stage led to granitic magma formation, and the other stage led to the formation of hybrid MME magma. The two processes were temporally and spatially distinct.

Either the granitic melt was derived from a metagreywacke crustal source and might have been contaminated during emplacement, or it was originally derived from a compositionally heterogeneous crustal protolith where some of the domains might have been metagreywacke and emplaced into the final chamber.

The parental melts of MMEs were derived from the partial melting of mafic (amphibolitic) lower crust influenced by underlying enriched lithospheric mantle. The hybridization process tended to modify the entire composition of the mafic magma by possibly interacting with fluids. Finally, the mafic magma reached the silicic magma chamber as small blobs and cooled in the nearly crystallized host magma. During this stage, the mingling-mixing textural features developed, and the original hybrid composition of the MMEs was changed due to isotopic and partial geochemical equilibration with the volumetrically prevailing granitic melt. The last process was one-sided as the influence of mafic melt on granitic melt was negligible due to the insignificant volume of the former.

On the basis of field observations, as well as geochemical and isotopic analyses supported by geochemical modelling, we conclude that the main process responsible for the differentiation of the parental melt of the HBG was fractional crystallization. In contrast to the granitic melt, the enclaves have chemical compositions that were mainly obtained by magma mixing-mingling, which likely occurred prior to or during emplacement, as well as in their current locations.

Composite plutons mainly show strong imprints of two end-member systems. Many of these plutons demonstrate that their entire range of granitic facies could have been produced by the mixing of crust- and mantle-derived magmas. Such a system dominated during the early stage of Variscan pluton formation. The pluton described in this paper belongs to the late stage of Variscan magmatism. It presents a multi-component system shaped by the participation of melts derived from heterogeneous crust domains. This pluton mimics the KCG system (granite with MMEs) but is only seemingly similar to those originating from a two-component system. The proper role of MMEs and their influence on pluton formation can be defined as one-sided reactions with granite magma with only a very limited local scope of mutual interactions. Thus, the presence of enclaves does not explicitly indicate their dominant role in the formation of composite plutons of crust-mantle origin. It is decisive to determine whether the ambiguous signatures appearing in such cases truly indicate both of these sources or merely one source with heterogeneous composition.

Acknowledgements The work has been funded by KBN Grant 2 P04D 045 28. We are very grateful to Herve Martin for stimulating discussions regarding the results and ideas presented here, as well as Lidia Jeżak for assistance in the microprobe laboratory. Constructive comments from the reviewers, Aleksandra Gawęda and Anonymous Reviewer, helped to improve our work.

Open Access This article is distributed under the terms of the Creative Commons Attribution 4.0 International License (http://creativeco mmons.org/licenses/by/4.0/), which permits unrestricted use, distribution, and reproduction in any medium, provided you give appropriate credit to the original author(s) and the source, provide a link to the Creative Commons license, and indicate if changes were made.

\section{References}

Aleksandrowski P, Kryza R, Mazur S, Żaba J (1997) Kinematic data on major Variscan strike-slip faults and shear zones in the Polish Sudetes, northeast Bohemian Massif. Geol Mag 134(5):727-739

Awdankiewicz M, Awdankiewicz H, Rapprich V, Stárková M (2014) A Permian andesitic tuff ring at Rožmitál (the Intra-Sudetic Basin, Czech Republic) — evolution from explosive to effusive and highlevel intrusive activity. Geol Q 58(4):759-778

Bacon CR, Druitt TH (1988) Compositional evolution of the zoned calcalkaline magma chamber of Mount Mazama, Crater Lake, Oregon. Contrib Mineral Petrol 98:224-256. https://doi.org/10.1007/ BF00402114

Badura J, Zuchiewicz W, Stepancikova P, Przybylski B, Kontny B, Cacon S (2007) The Sudetic Marginal Fault: a young morphophotectonic feature at the NE margin of the Bohemian Massif, Central Europe. Acta Geodyn Geomater 4(4):7

Baranowski Z, Haydukiewicz A, Kryza R, Lorenc S, Muszyński A, Solecki A, Urbanek Z (1990) Outline of the geology of the Góry Kaczawskie (Sudetes, Poland). Neues Jahrb Geol Paläontol 179:223-257

Barbarin B (1988) Field evidence for successive mixing and mingling between the Piolard Diorite and the Saint-Julien-la-Vêtre Monzogranite (Nord-Forez, Massif Central, France). Can J Earth Sci 25(1):49-59. https://doi.org/10.1139/e88-005

Barbarin B (1991) Enclaves of the Mesozoic calc-alkaline granitoids of the Sierra Nevada Batholith, California. In: Didier J, Barbarin B (eds) Enclaves and granite petrology. Elsevier, Amsterdam, pp 135-153

Barbarin B (1999) A review of the relationships between granitoid types, their origins and their geodynamic environments. Lithos 46(3):605-626 
Barbarin B (2005) Mafic magmatic enclaves and mafic rocks associated with some granitoids of the central Sierra Nevada batholith, California: nature, origin, and relations with the hosts. Lithos 80(1-4):155-177

Barbarin B, Didier J (1992) Genesis and evolution of mafic microgranular enclaves through various types of interaction between coexisting felsic and mafic magmas. Earth Env Sci T R So 83(1-2):145-153

Barth MG, McDonough WF, Rudnick RL (2000) Tracking the budget of $\mathrm{Nb}$ and $\mathrm{Ta}$ in the continental crust. Chem Geol 165(3-4):197-213

Bea F, Pereira MD, Stroh A (1994) Mineral/leucosome trace-element partitioning in a peraluminous migmatite (a laser ablation-ICPMS study). Chem Geol 117(1-4):291-312

Castro A, Moreno-Ventas I, de la Rosa JD (1990) Microgranular enclaves as indicators of hybridization processes in granitoid rocks, Hercynian Belt, Spain. Geol J 25:391-404. https://doi. org/10.1002/gj.3350250321

Castro A, Moreno-Ventas I, De La Rosa JD (1991) H-type (hybrid) granitoids: a proposed revision of the granite-type classification and nomenclature. Earth Sci Rev 31(3-4):237-253

Chen B, Chen ZC, Jahn BM (2009) Origin of mafic enclaves from the Taihang Mesozoic orogen, north China craton. Lithos 110(1):343-358

Cocherie A (1986) Systematic use of trace element distribution patterns in log-log diagrams for plutonic suites. Geochim Cosmochim Ac 50(11):2517-2522

De Campos CP, Perugini D, Dingwell DB, Civetta L, Fehr TK (2008) Heterogeneities in Magma Chambers: insights from the behavior of major and minor elements during mixing experiments with natural alkaline melts. Chem Geol 256:131-145

De Campos CP, Perugini D, Ertel-Ingrisch W, Dingwell DB, Poli G (2011) Enhancement of magma mixing efficiency by chaotic dynamics: an experimental study. Contrib Mineral Petrol 161:863-881

DePaolo DJ (1981) Neodymium isotopes in the Colorado Front Range and crust-mantle evolution in the Proterozoic. Nature 291(5812): 193

DePaolo DJ, Wasserburg GL (1976) Nd isotopic variations and petrogenetic models. Geophys Res Lett 3:249-252

Didier J (1973) Granites and their enclaves; the bearing of enclaves on the origin of granites. Elsevier Scientific Pub. Co, Amsterdam

Didier J (1987) Contribution of enclave studies to the understanding of origin and evolution of granitic magmas. Geol Rundschau 76:41-50. https://doi.org/10.1007/BF01820572

Didier J, Barbarin B (1991) The different types of enclaves in granitesNomenclature. In: Didier J, Barbarin B (eds) Enclaves and granite petrology. Elsevier, Amsterdam, pp 19-23

Dodge FCW, Kistler RW (1990) Some additional observations on inclusions in the granitic rocks of the Sierra Nevada. J Geophys Res 95:17841-17848. https://doi.org/10.1029/JB095iB11p17841

Domańska K (1984) Petrografia i geneza ciemnych enklaw w NWczęści masywu granitoidowego Strzegom-Sobótka. Dissertation, University of Wrocław (in Polish)

Domańska J, Słaby E (2004) The hornblende-biotite granite from the Strzegom-Sobótka massif-parental magma evolution. Mineral Soc Poland Spec Papers 24:131-134

Domańska-Siuda J, Słaby E (2005) One-sided contamination of lamprophyric melt drops in hornblende-biotite granite magma chamber-a case study of Strzegom massif (SW Poland). Mineral Soc Poland Spec Papers 25:67-70

Donaire T, Pascual E, Pin C, Duthou J-L (2005) Microgranular enclaves as evidence of rapid cooling in granitoid rocks: the case of the Los Pedroches granodiorite, Iberian Massif, Spain. Contrib Mineral Petrol 149:247-265. https://doi.org/10.1007/ s00410-005-0652-0
Downes H (1993) The nature of the lower continental crust of Europe: petrological and geochemical evidence from xenoliths. Phys Earth Planet In 79(1-2):195-218. https://doi.org/10.1016/00319201(93)90148-3

Dubińska E, Bylina P, Kozlowski A, Dörr W, Nejbert K, Schastok J (2004) U-Pb dating of serpentinization: Hydrothermal zircon from a metasomatic rodingite shell (Sudetic ophiolite, SW Poland). Chem Geol 203:183-203

Ercit TS (2002) The mess that is "allanite". Can Mineral 40(5):1411-1419

Ewart A, Griffin WL (1994) Application of proton-microprobe data to trace-element partitioning in volcanic rocks. Chem Geol 117(1-4):251-284

Farner M, Lee C, Putirka KD (2014) Mafic-felsic magma mixing limited by reactive processes: A case study of biotite-rich rinds on mafic enclaves. Earth Planet Sci Lett 393:49-59

Feeley T, Wilson L, Underwood SJ (2008) Distribution and compositions of magmatic inclusions in the Mount Helen dome, Lassen Volcanic Center, California: insights into magma chamber processes. Lithos 106(1-2):173-189

Fernandez A, Barbarin B (1991) Relative rheology of coeval mafic and felsic magmas: nature of resulting interaction processes and shape and mineral fabrics of mafic microgranular enclaves. In: Didier J, Barbarin B (eds) Enclaves and granite petrology. Elsevier, Amsterdam, pp 263-275

Finger F, Roberts MP, Haunschmid B, Schermaier A, Steyrer HP (1997) Variscan granitoids of central Europe: their typology, potential sources and tectonothermal relations. Mineral Petrol 61:67-96. https://doi.org/10.1007/BF01172478

Finger F, Gerdes A, Janoušek V, René M, Riegler G (2007) Resolving the Variscan evolution of the Moldanubian sector of the Bohemian Massif: the significance of the Bavarian and the Moravo-Moldanubian tectonometamorphic phases. J Geosci Czech 52:9-28

Finger F, Gerdes A, René M, Riegler G (2009) The Saxo-Danubian Granite Belt: magmatic response to post-collisional delamination of mantle lithosphere below the southwestern sector of the Bohemian Massif. Geol Carpath 60(3):205-212

Floyd PA, Shail R, Leveridge BE, Franke W (1991) Geochemistry and provenance of Rhenohercynian synorogenic sandstones: implications for tectonic environment discrimination. Geol Soc London Spes Publ 57:173-188

Foster MD (1960) Interpretation of the composition of trioctahedral micas. U.S. Geol Surv, Prof Pap 354-B, 11-49

Fourcade S, Allegre CJ (1981) Trace elements behavior in granite genesis: a case study The calc-alkaline plutonic association from the Querigut complex (Pyrénées, France). Contrib Mineral Petrol 76:177-195. https://doi.org/10.1007/BF00371958

Fourcade S, Javoy M (1991) Sr-Nd-O isotopic features of mafic microgranular enclaves and host granitoids from the Pyrenees, France: evidence for their hybrid nature and inference on their origin. In: Didier J, Barbarin B (eds) Enclaves and granite petrology. Elsevier, Amsterdam, pp 345-365

Franke W (2000) The mid-European segment of the Variscides: tectonostratigraphic units, terrane boundaries and plate tectonic evolution. Geol Soc, London, Sp Publ 179(1):35-61

Frost TP, Mahood GA (1987) Field, chemical, and physical constraints on mafic-felsic magma interaction in the Lamarck Granodiorite, Sierra Nevada, California. Geol Soc Am Bull 99(2):272-291

Frost BR, Barnes CG, Collins WJ, Arculus RJ, Ellis DJ, Frost CD (2001) A geochemical classification for granitic rocks. J Petrol 42(11):2033-2048

Furman T, Spera FJ (1985) Co-mingling of acid and basic magma with implications for the origin of mafic I-type xenoliths: field and petrochemical relations of an unusual dike complex at Eagle 
Lake, Sequoia National Park, California, USA. J Volcanol Geoth Res 24(1-2):151-178

Gerdes A, Wörner G (2000) Hybrids, magma mixing and enriched mantle melts in post-collisional Variscan granitoids: the Rastenberg Pluton, Austria. Geol Soc Lond Sp Publ 179(1):415-431

Green TH (1995) Significance of $\mathrm{Nb} / \mathrm{Ta}$ as an indicator of geochemical processes in the crust-mantle system. Chem Geol 120(3-4):347-359

Grocholski A, Sawicki L (1992) Stan rozpoznania strukturalnego i kierunki badań Dolnego Śląska. Inst Geol, Wrocław (in Polish)

Gunia T (1999) Microfossils from the high-grade metamorphic rocks of the Góry Sowie Mts. (Sudetes area) and their stratigraphic importance. Geol Quart 43(4):519-536

Hawkesworth CJ, Kemp AIS (2006) The differentiation and rates of generation of the continental crust. Chem Geol 226(3-4):134-143

Hawthorne FC, Oberti R, Harlow GE, Maresch WV, Martin RF, Schumacher JC, Welch MD (2012) Nomenclature of the amphibole supergroup. Am Mineral 97(11-12):2031-2048

Henk A (1997) Gravitational orogenic collapse vs plate-boundary stresses: a numerical modelling approach to the Permo-Carboniferous evolution of Central Europe. Geol Rundsch 86:39-55. https://doi.org/10.1007/s005310050120

Hibbard MJ (1991) Textural anatomy of twelve magma-mixed granitoid systems. In: Didier J, Barbarin B (eds) Enclaves and granite petrology. Elsevier, Amsterdam, pp 431-444

Holden P, Halliday A, Stephens WE (1987) Neodymium and strontium isotope content of microdiorite enclaves points to mantle input to granitoid production. Nature 330(6143):53

Holden P, Halliday AN, Stephens WE, Henney PJ (1991) Chemical and isotopic evidence for major mass transfer between mafic enclaves and felsic magma. Chem Geol 92(1-3):135-152

Hrouda F, Táborská Š, Schulmann K, Ježek J, Dolejš D (1999) Magnetic fabric and rheology of co-mingled magmas in the Nasavrky Plutonic Complex (E Bohemia): implications for intrusive strain regime and emplacement mechanism. Tectonophysics 307(1-2):93-111

Irvine TN, Baragar WRA (1971) A guide to the chemical classification of the common volcanic rocks. Can J Earth Sci 8:523-548

Janeczek J (2007) Intragranitic pegmatites of the Strzegom-Sobótka massif-an overview. In: Kozłowski A, Wiszniewska J (eds) Granitoids in Poland, AM Monograph 1, pp 193-201

Janoušek V, Braithwaite CJ, Bowes DR, Gerdes A (2004) Magmamixing in the genesis of Hercynian calc-alkaline granitoids: an integrated petrographic and geochemical study of the Sázava intrusion, Central Bohemian Pluton, Czech Republic. Lithos 78(1-2):67-99

Jerzmański J (1970) Neue Ergebnisse im westlichen Teil des Blök przedsudecki. Ber Dtsch Ges Geol Wiss A Geol Paläontol 15:305-313 (In German)

Jerzmański J, Teller L (1971) The Lower Ludlovian in borehole Biskupin IG-1 (western part of the Fore-Sudetic Block). Bull Acad Pol Sci Sér Sci Terre 19:157-160

Johannes W, Holtz F (1996) Petrogenesis and experimental petrology of granitic rocks. In: Wyllie PJ, El Goresy A, von Engelhardt W, Hahn T (eds) Minerals and rocks, vol 22, pp 335

Jung C, Jung S, Hellebrand E, Hoffer E (2009) Trace element constraints on mid-crustal partial melting processes-a garnet ion probe study from polyphase migmatites (Damara orogen, Namibia). Earth Env Sci T R Soc 100(1-2):205-218

Kennan PS, Dziedzic H, Lorenc MW, Mierzejewski MP (1999) A review of $\mathrm{Rb}-\mathrm{Sr}$ isotope patterns in the Carboniferous granitoids of the Sudetes in SW Poland. Geol Sudet 32(1-74):49-53

Kocak K, Zedef V (2016) Interaction of the lithospheric mantle and crustal melts for the generation of the Horoz pluton (Nigde,
Turkey): whole-rock geochemical and $\mathrm{Sr}-\mathrm{Nd}-\mathrm{Pb}$ isotopic evidence. Est J Earth Sci 65(3):138

Kocak K, Zedef V, Kansun G (2011) Magma mixing/mingling in the Eocene Horoz (Nigde) granitoids, Central southern Turkey: evidence from mafic microgranular enclaves. Mineral Petrol 103(1-4):149-167. https://doi.org/10.1007/s00710-011-0165-7

Kryza R, Awdankiewicz M (2012) Ambiguous geological position of Carboniferous rhyodacites in the Intra-Sudetic Basin (SW Poland) clarified by SHRIMP zircon ages. Geol Q 56(1):55-66

Kryza R, Fanning CM (2007) Devonian deep-crustal metamorphism and exhumation in the Variscan Orogen: evidence from SHRIMP zircon ages from HT-HP granulites and migmatites of the Góry Sowie (Polish Sudetes). Geodin Acta 20(3):159-175

Kryza R, Muszyński A (1992) Pre-Variscan volcanic-sedimentary succession of the central southern Góry Kaczawskie, SW Poland: outline geology. Ann Soc Geol Pol 62(2):117-140

Kryza R, Pin C (2010) The Central-Sudetic ophiolites (SW Poland): petrogenetic issues, geochronology and palaeotectonic implications. Gondwana Res 17(2-3):292-305

Kryza R, Zalasiewicz J (2008) Records of Precambrian-early Palaeozoic volcanic and sedimentary processes in the Central European Variscides: a review of SHRIMP zircon data from the Kaczawa succession (Sudetes, SW Poland). Tectonophysics 461(1-4):60-71

Kumar S (2010) Mafic to hybrid microgranular enclaves in the Ladakh batholith, northwest Himalaya: Implications on calc-alkaline magma chamber processes. J Geol Soc India 76(1):5-25. https ://doi.org/10.1007/s12594-010-0080-2

Kumar S, Rino V (2006) Mineralogy and geochemistry of microgranular enclaves in Palaeoproterozoic Malanjkhand granitoids, central India: evidence of magma mixing, mingling, and chemical equilibration. Contrib Mineral Petrol 152(5):591-609

Kural S, Morawski T (1968) Strzegom-Sobótka granitic massif. Biul Inst Geol 227(17):33-74

Laurent A, Janousek V, Magna T, Schulmann K, Mikova J (2014) Petrogenesis and geochronology of a post-orogenic calc-alkaline magmatic association: the Zulova Pluton, Bohemian Massif. J Geosci-Czech 59(4):415-440

Laurent O, Zeh A, Gerdes A, Villaros A, Gros K, Słaby E (2017) How do granitoid magmas mix with each other? Insights from textures, trace element and $\mathrm{Sr}-\mathrm{Nd}$ isotopic composition of apatite and titanite from the Matok pluton (South Africa). Contrib Mineral Petrol 172:80. https://doi.org/10.1007/s00410-017-1398-1

Lesher CE (1990) Decoupling of chemical and isotopic exchange during magma mixing. Nature 344(6263):235

Liu L, Qiu JS, Li Z (2013) Origin of mafic microgranular enclaves (MMEs) and their host quartz monzonites from the Muchen pluton in Zhejiang Province, Southeast China: implications for magma mixing and crust-mantle interaction. Lithos 160:145163. https://doi.org/10.1016/j.lithos.2012.12.005

Locock AJ (2014) An Excel spreadsheet to classify chemical analyses of amphiboles following the IMA 2012 recommendations. Comput Geosci UK 62:1-11

Ludwig KR (2000) Isoplot/Ex version 2.4. A Geochronological Toolkit for Microsoft Excel, Berkeley Geochron Centre Spec Publ, pp 1-56

Maciejewski S, Morawski T (1975) Zmienność petrograficzna granitów masywu strzegomskiego. Geol Q 19(1):47-66 (in Polish)

Mahood G, Hildreth W (1983) Large partition coefficients for trace elements in high-silica rhyolites. Geochim Cosmochim Ac 47(1):11-30

Majerowicz A (1972) Masyw granitowy Strzegom-Sobótka. Geol Sudet 6:7-96 (in Polish)

Maniar PD, Piccoli PM (1989) Tectonic discrimination of granitoids. Geol Soc Am Bull 101:635-643 
Martin RF (2006) A-type granites of crustal origin ultimately result from open-system fenitization-type reactions in an extensional environment. Lithos 91:125-136

Martin RF, De Vito C (2005) The patterns of enrichment in felsic pegmatites ultimately depend on tectonic setting. Can Mineral 43:2027-2048

Mazur S, Aleksandrowski P, Kryza R, Oberc-Dziedzic T (2006) The Variscan Orogen in Poland. Geol Q 50(1):89-118

Mazur S, Aleksandrowski P, Turniak K, Awdankiewicz M (2007) Geology, tectonic evolution and Late Palaeozoic magmatism of Sudetes-an overview. In: Kozłowski A, Wiszniewska J (eds) Granitoids in Poland, AM Monograph 1, pp 59-87

McLeod GW, Dempster TJ, Faithfull JW (2010) Deciphering magmamixing processes using zoned titanite from the Ross of Mull Granite, Scotland. J Petrol 52(1):55-82

Michel L, Wenzel T, Markl G (2016) Interaction between two contrasting magmas in the Albtal pluton (Schwarzwald, SW Germany): textural and mineral-chemical evidence. Int J Earth Sci 106(5):1505-1524

Miles AJ, Graham CM, Hawkesworth CJ, Gillespie MR, Hinton RW (2013) Evidence for distinct stages of magma history recorded by the compositions of accessory apatite and zircon. Contrib Mineral Petrol 166(1):1-19

Miller CF (1985) Are strongly peraluminous magmas derived from pelitic sedimentary sources? J Geol 93:673-689. https://doi. org/10.1086/628995

Nakamura N (1974) Determination of REE, Ba, Fe, Mg, Na and $\mathrm{K}$ in carbonaceous and ordinary chondrites. Geochim Cosmochim Ac 38(5):757-775

Nash WP, Crecraft HR (1985) Partition coefficients for trace elements in silicic magmas. Geochim Cosmochim Ac 49(11):2309-2322

Oberc-Dziedzic T, Kryza R, Pin C, Madej S (2013) Variscan granitoid plutonism in the Strzelin Massif (SW Poland): petrology and age of the composite Strzelin granite intrusion. Geol Q 57(2):269-288

Oberc-Dziedzic T, Pin C, Madej S, Kryza R (2016) Three generations of granitoids emplaced over a $300 \mathrm{My}$ time span in the Strzelin Massif, Fore-Sudetic Block, SW Poland: mutual relationships and implications for secular crustal evolution. J Geosci Czech 61(4):289-308

Oliver GJH, Corfu F, Krogh TE (1993) U-Pb ages from SW Poland: evidence for a Caledonian suture zone between Baltica and Gondwana. J Geol Soc 150:355-369

Orsini JB, Cocirta C, Zorpi MJ (1991) Genesis of mafic microgranular enclaves through differentiation of basic magmas, mingling and chemical exchanges with their host granitoid magmas. In: Didier J, Barbarin B (eds) Enclaves and granite petrology. Elsevier, Amsterdam, pp 445-464

Palme H, O'Neill H (2014) Cosmochemical estimates of mantle composition. In: Carlson RW, Holland HD, Turekian KK (eds) Treatise on Geochemistry 2, 2nd edn. Elsevier, Oxford, pp 1-38

Paterson SR, Pignotta GS, Vernon RH (2004) The significance of microgranitoid enclave shapes and orientations. J Struct Geol 26(8):1465-1481

Patiño Douce AE (1999) What do experiments tell us about the relative contributions of crust and mantle to the origin of granitic magmas? Geol Soc London Spec Publ 168(1):55-75

Pearce JA (2008) Geochemical fingerprinting of oceanic basalts with applications to ophiolite classification and the search for Archean oceanic crust. Lithos 100(1-4):14-48

Pearce JA, Norry MJ (1979) Petrogenetic implications of Ti, Zr, Y, and $\mathrm{Nb}$ variations in volcanic rocks. Contrib Mineral Petrol 69:33-47. https://doi.org/10.1007/BF00375192
Perugini D, Poli G (2000) Chaotic dynamics and fractals in magmatic interaction processes: a different approach to the interpretation of mafic microgranular enclaves. Earth Planet Sci Lett 175:93-103

Perugini D, Poli G (2012) The mixing of magmas in plutonic and volcanic environments: analogies and differences. Lithos 153:261-277

Philpotts JA, Schnetzler CC (1970) Phenocryst-matrix partition coefficients for $\mathrm{K}, \mathrm{Rb}, \mathrm{Sr}$ and $\mathrm{Ba}$, with applications to anorthosite and basalt genesis. Geochim Cosmochim Ac 34(3):307-322

Pieczka A, Szuszkiewicz A, Szełęg E, Janeczek J, Nejbert K (2015) Granitic pegmatites of the Polish part of the Sudetes (NE Bohemian massif, SW Poland). PEG 2015 7th International Symposium on Granitic Pegmatites, fieldtrip guidebook, pp 73-102

Pietranik A, Koepke J (2009) Interactions between dioritic and granodioritic magmas in mingling zones: plagioclase record of mixing, mingling and subsolidus interactions in the Gęsiniec Intrusion, NE Bohemian Massif, SW Poland. Contrib Miner Petrol 158(1):17. https://doi.org/10.1007/s00410-008-0368-z

Pietranik A, Koepke J (2014) Plagioclase transfer from a host granodiorite to mafic microgranular enclaves: diverse records of magma mixing. Mineral Petrol 108:681-694. https://doi.org/10.1007/ s00710-014-0326-6

Pietranik A, Waight TE (2008) Processes and sources during Late Variscan dioritic-tonalitic magmatism: insights from plagioclase chemistry (Gęsiniec Intrusion, NE Bohemian Massif, Poland). J Petrol 49(9):1619-1645

Pin C, Puziewicz J, Duthou JL (1988) Studium izotopowe Rb-Sr oraz Sm-Nd masywu granitoidowego Strzegom-Sobótka. In: Petrologia i geologia fundamentu warysyjskiego polskiej części Sudetów, pp 37-41 (in Polish)

Pin C, Puziewicz J, Duthou JL (1989) Ages and origins of a composite granitic massif in the Variscan belt: A Rb-Sr study of the Strzegom-Sobótka Massif, W Sudetes (Poland). Neues Jb Minerb Abh 160:71-82

Pin C, Binon M, Belin JM, Barbarin B, Clemens JD (1990) Origin of microgranular enclaves in granitoids: Equivocal $\mathrm{Sr}-\mathrm{Nd}$ evidence From Hercynian Rocks in the Massif Central (France). J Geophys Res-Sol Ea 95(B11):17821-17828. https://doi.org/10.1029/ JB095iB11p17821

Poli GE, Tommasini S (1991) Model for the origin and significance of microgranular enclaves in calc-alkaline granitoids. J Petrol 32(3):657-666. https://doi.org/10.1093/petrology/32.3.657

Poli G, Tommasini S, Halliday AN (1996) Trace element and isotopic exchange during acid-basic magma interaction processes. Earth Env Sci T R So 87(1-2):225-232

Puziewicz J (1985) Petrologia skał masywu granitowego StrzegomSobótka In: Petrologia skał masywu granitowego StrzegomSobótka i jego osłony, pp 19-27 (in Polish)

Puziewicz J (1990) Masyw granitowy Strzegom-Sobótka. Aktualny stan badań. Arch Mineral 45(1):135-151 (in Polish with English abstract)

Puziewicz J (1994) Zawartość tytanu w biotycie z granitoidów jako wskaźnik warunków krystalizacji magmy. Studium biotytu z metaaluminowych granitoidów masywu Strzegom-Sobótka. Arch Mineral 50(1):89-134

Puziewicz J (1995) Titanium zoning in biotites-an example from the Strzegom-Sobotka granites (SW Poland). Neues Jb Miner Monatshefte (7):289-305

Ratajeski K, Glazner AF, Miller BV (2001) Geology and geochemistry of mafic to felsic plutonic rocks in the Cretaceous intrusive suite of Yosemite Valley, California. Geol Soc Am Bull 113(11):1486-1502

Rayleigh L (1896) Theoretical considerations respecting the separation of gases by diffusion and similar processes. Lond 
Edinburgh Dublin Philos Mag J Sci 42(259):493-498. https:// doi.org/10.1080/14786449608620944

Reid JB, Evans OC, Fates DG (1983) Magma mixing in granitic rocks of the central Sierra Nevada, California. Earth Planet Sci Lett 66:243-261

Rickwood PC (1989) Boundary lines within petrologic diagrams which use oxides of major and minor elements. Lithos 22(4):247-263

Roberts MP, Clemens JD (1993) Origin of high-potassium, calc-alkaline, I-type granitoids. Geology 21(9):825-828

Rudnick RL (1992) Xenoliths-samples of the lower continental crust. In: Fountain DM, Arculus R, Kay RW (eds) Continental lower crust, pp. 269-316

Rudnick RL, Fountain DM (1995) Nature and composition of the continental crust - a lower crustal perspective. Rev Geophys 33:267-309

Rudnick RL, Gao S (2003) Composition of the continental crust. In: Rudnick RL, Holland HD, Turekian KK (eds) Treatise on geochemistry 3. Elsevier, Oxford, pp 1-64

Ryerson FJ, Hess PC (1978) Implications of liquid-liquid distribution coefficients to mineral-liquid partitioning. Geochim Cosmochim Ac 42(6):921-932

Schaltegger U (1997) Magma pulses in the Central Variscan Belt: episodic melt generation and emplacement during lithospheric thinning. Terra Nova 9(5-6):242-245. https://doi. org/10.1111/j.1365-3121.1997.tb00021.x

Silva MMVG, Neiva AMR, Whitehouse MJ (2000) Geochemistry of enclaves and host granites from the Nelas area, central Portugal. Lithos 50(1-3):153-170. https://doi.org/10.1016/S0024 $-4937(99) 00053-5$

Słaby E, Götze J (2004) Feldspar crystallization under magma-mixing conditions shown by cathodoluminescence and geochemical modelling-a case study from the Karkonosze pluton (SW Poland). Min Mag 68(4):561-577. https://doi.org/10.1180/00264 61046840205

Słaby E, Martin H (2008) Mafic and felsic magma interaction in granites: the Hercynian Karkonosze Pluton (Sudetes, Bohemian Massif). J Petrol 49(2):353-391. https://doi.org/10.1093/petrology/ egm085

Słaby E, Galbarczyk-Gąsiorowska L, Seltmann R, Mueller A (2007a) Alkali feldspar megacryst growth: geochemical modelling. Min Petrol 89:1-29

Słaby E, Seltmann R, Kober B, Müller A, Galbarczyk-Gąsiorowska L, Jeffries T (2007b) LREE distribution patterns in zoned alkali feldspar megacrysts-implication for parental melt composition. Min Mag 71:193-217

Słaby E, Götze J, Wörner G, Simon K, Wrzalik R, Śmigielski M (2008) K-feldspar phenocrysts in microgranular magmatic enclaves: a cathodoluminescence and geochemical study of crystal growth as a marker of magma mingling dynamics. Lithos 105:85-97

Słaby E, Martin H, Hamada M, Śmigielski M, Domonik A, Götze J, Hoefs J, Hałas S, Simon K, Devidal JL, Moyen JF, Yajananda M (2012) Evidence in Archaean alkali feldspar megacrysts for hightemperature interaction with mantle fluids. J Petrol 53:67-98

Sparks RSJ, Marshall LA (1986) Thermal and mechanical constraints on mixing between mafic and silicic magmas. J Volcanol Geotherm Res 29(1-4):99-124. https://doi.org/10.1016/03770273(86)90041-7

Stephens WE, Holden P, Henney PJ (1991) Microdioritic enclaves within the Scottish Caledonian granitoids and their significance for crustal magmatism. In: Didier J, Barbarin B (eds) Enclaves and granite petrology. Elsevier, Amsterdam, pp 125-134

Stimac J, Hickmott D (1994) Trace-element partition coefficients for ilmenite, orthopyroxene and pyrrhotite in rhyolite determined by micro-PIXE analysis. Chem Geol 117(1-4):313-330
Stormer JJC, Nicholls J (1978) XLFRAC: a program for the interactive testing of magmatic differentiation models. Comput Geosci UK 4(2):143-159

Sun SS, McDonough WS (1989) Chemical and isotopic systematics of oceanic basalts: implications for mantle composition and processes. Geol Soc Lond Sp Publ 42(1):313-345

Sylvester PJ (1998) Post-collisional strongly peraluminous granites. Lithos 45(1-4):29-44

Teixeira RN (1996) O Complexo Caraiba e a Suite Săo José de Jacuipe no Cinturăo Móvel Salvador-Curaçá (BA, Brasil): petrologia, geoquimica e potencial metalogenica. Doctoral Thesis (in Portuguese)

Turnbull R, Weaver S, Tulloch A, Cole J, Handler M, Ireland T (2010) Field and geochemical constraints on mafic-felsic interactions, and processes in high-level arc magma chambers: an example from the Halfmoon Pluton, New Zealand. J Petrol 51(7):14771505. https://doi.org/10.1093/petrology/egq026

Turniak K, Halas S, Wójtowicz A (2007) New K-Ar cooling ages of granitoids from the Strzegom-Sobótka Massif, SW Poland. Geochronometria 27(1):5-9. https://doi.org/10.2478/v1000 3-007-0019-9

Turniak K, Mazur S, Domańska-Siuda J, Szuszkiewicz A (2014) SHRIMP U-Pb zircon dating for granitoids from the Strzegom-Sobótka Massif, SW Poland: Constraints on the initial time of Permo-Mesozoic lithosphere thinning beneath Central Europe. Lithos 208-209:415-429. https://doi.org/10.1016/j.litho s.2014.09.031

Ubide T, Galé C, Larrea P, Arranz E, Lago M, Tierz P (2014) The relevance of crystal transfer to magma mixing: a case study in composite dykes from the central pyrenees. J Petrol 55(8):15351559. https://doi.org/10.1093/petrology/egu033

Vernon RH (1983) Restite, xenoliths and microgranitoid enclaves in granites. J Proc Roy Soc New South Wales 116:77-103

Vernon RH (1984) Microgranitoid enclaves in granites-globules of hybrid magma quenched in a plutonic environment. Nature 309(5967):438

Vernon RH (1990) Crystallization and hybridism in microgranitoid enclave magmas: microstructural evidence. J Geophys Res Sol Ea 95(B11):17849-17859. https://doi.org/10.1029/JB095iB11p 17849

Vernon RH (1991) Interpretation of microstructures of microgranitoid enclaves. In: Didier J, Barbarin B (eds) Enclaves and granite petrology. Elsevier, Amsterdam, pp 277-291

Vernon RH (2010) Granites really are magmatic: using microstructural evidence to refute some obstinate hypotheses. In: Forster MA, Gerald JDF (eds) The science of microstructure - Part I, J Virt Exp. https://doi.org/10.3809/jvirtex.2011.00264

Vernon RH, Etheridge MA, Wall VJ (1988) Shape and microstructure of microgranitoid enclaves: indicators of magma mingling and flow. Lithos 22(1):1-11

Waight TE, Maas R, Nicholls IA (2000) Fingerprinting feldspar phenocrysts using crystal isotopic composition stratigraphy: implications for crystal transfer and magma mingling in S-type granites. Contrib Mineral Petrol 139:227-239

Waight TE, Maas R, Nicholls IA (2001) Geochemical investigations of microgranitoid enclaves in the S-type Cowra Granodiorite, Lachlan Fold Belt, SE Australia. Lithos 56(2-3):165-186. https ://doi.org/10.1016/S0024-4937(00)00053-0

Walker GP, Skelhorn RR (1966) Some associations of acid and basic igneous rocks. Earth-Sci Rev 2:93-109

Watson EB (1976) Two-liquid partition coefficients: experimental data and geochemical implications. Contrib Miner Petrol 56(1):119_ 134. https://doi.org/10.1007/BF00375424

Wichrowska M (1974) Biotyty z granitów strzegomskich. Geol Q 18:33-44 (in Polish) 
Wichrowska M (1977) Pierwiastki śladowe w łyszczykach z granitoidów masywu Strzegom-Sobótka i Strzelin-Žulová (Trace elements in micas from granitoids of Strzegom-Sobótka and Strzelin-Žulová Massif). Biul Inst Geol 298:209-261 (in Polish)

Wiebe RA, Collins WJ (1998) Depositional features and stratigraphic sections in granitic plutons: implications for the emplacement and crystallization of granitic magma. J Struct Geol 20(9-10):1273-1289

Wiebe RA, Smith D, Sturm M, King EM, Seckler M (1997) Enclaves in the Cadillac Mountain Granite (Coastal Maine) samples of hybrid magma from the base of the chamber. J Petrol 38:393-423

Wilson M (1989) Igneous petrogenesis—a global tectonic approach. Unwin Hyman, London

Wyllie PJ, Cox KG, Biggar GM (1962) The habit of apatite in synthetic systems and igneous rocks. J Petrol 3:238-243

Yurimoto H, Duke EF, Opapike JJ, Shearer CK (1990) Are discontinuous chondrite-normalized REE patterns in pegmatic granite systems the results of monazite fractionation? Geochim Cosmochim Ac 54:2141-2145

Žák J, Verner K, Sláma J, Kachlík V, Chlupáčová M (2013) Multistage magma emplacement and progressive strain accumulation in the shallow-level Krkonoše-Jizera plutonic complex, Bohemian Massif. Tectonics 32(5):1493-1512. https://doi.org/10.1002/ tect. 20088

Žák J, Verner K, Janoušek V, Holub FV, Kachlík V, Finger F, Hajná J, Tomek F, Vondrovic L, Trubač J (2014) A plate-kinematic model for the assembly of the Bohemian Massif constrained by structural relationships around granitoid plutons. In: Schulmann K, Martínez Catalán JR, Lardeaux JM, Janoušek V, Oggiano G (eds) The Variscan orogeny: extent, timescale and the formation of the european crust. Geol Soc, London, Sp Publ 405, pp 169-196. https://doi.org/10.1144/SP405.9

Żelaźniewicz A (1997) The Sudetes as a Palaeozoic orogen in central Europe. Geol Mag 134(5):691-702

Zhang J, Wang T, Castro A, Zhang L, Shi X, Tong Y, Zhang Z, Guo L, Yang Q, Iaccheri LM (2016) Multiple Mixing and Hybridization from Magma Source to Final Emplacement in the Permian Yamatu Pluton, the Northern Alxa Block, China. J Petrol 57(5):934-979. https://doi.org/10.1093/petrology/egw028 